\title{
Review: Neuronal Differentiation Protocols of Mesenchymal Stem Cells
}

\author{
Miguel A. Jiménez-Acosta ${ }^{1}$, Lory Jhenifer Rochín Hernández ${ }^{1}$, Mayte Lizeth Padilla Cristerna ${ }^{1}$, \\ José Tapia-Ramírez², Marco A. Meraz-Ríos ${ }^{*}$ \\ ${ }^{1}$ Department of Molecular Biomedicine, Centro de Investigación y de Estudios Avanzados del Instituto Politécnico Nacional, \\ Instituto Politécnico Nacional, México City, México \\ ${ }^{2}$ Department of Genetic and Molecular Biology, Centro de Investigación y de Estudios Avanzados del Instituto Politécnico \\ Nacional, Instituto Politécnico Nacional, México City, México
}

Email: ^mmeraz@cinvestav.mx

How to cite this paper: Jiménez-Acosta, M.A., Hernández, L.J.R., Cristerna, M.L.P., Tapia-Ramírez, J. and Meraz-Ríos, M.A. (2022) Review: Neuronal Differentiation Protocols of Mesenchymal Stem Cells. Advances in Bioscience and Biotechnology, 13, 15-71. https://doi.org/10.4236/abb.2022.131002

Received: December 9, 2021

Accepted: January 26, 2022

Published: January 29, 2022

Copyright (c) 2022 by author(s) and Scientific Research Publishing Inc. This work is licensed under the Creative Commons Attribution International License (CC BY 4.0).

http://creativecommons.org/licenses/by/4.0/

\begin{abstract}
Mesenchymal stem cells (MSCs) are self-renewing cells found in almost all postnatal organs and tissues in the perivascular region. These cells present multiple characteristics that make them candidates to be applied in cell therapy for neurodegenerative diseases, such as their secretory action, migration to the lesion area, and immunomodulatory potential. These cells have a high capacity for mesodermal differentiation; however, numerous studies have shown that MSCs can also differentiate into neurons. However, despite positive results in multiple trials in which undifferentiated MSCs transplanted into animal models of neurodegenerative diseases, some studies suggest that the therapeutic effects obtained are enhanced by the use of MSCs differentiated towards the neuronal lineage before transplant. In this sense, there are several methods to induce in vitro reprogramming of MSCs towards the neuronal lineage, including chemical substances, growth factors, cocultures with neural lineage cells, transfection of genes, miRNAs, etc., and small molecules stand out. Therefore, this article compares multiple experimental tests in which these inducers promote neuronal differentiation of MSCs and identify those methods that originate an optimal neuronal differentiation. The analysis includes the percentage of differentiation, maturation, expression of neuronal markers, functionality, and cell survival considering the intrinsic characteristics of the MSCs used as the tissue of origin and the species from which they were isolated.
\end{abstract}

\section{Keywords}

Mesenchymal Stem Cells, Transdifferentiating, Neuronal Differentiation, Small Molecules, miRNA, Neural Induction 


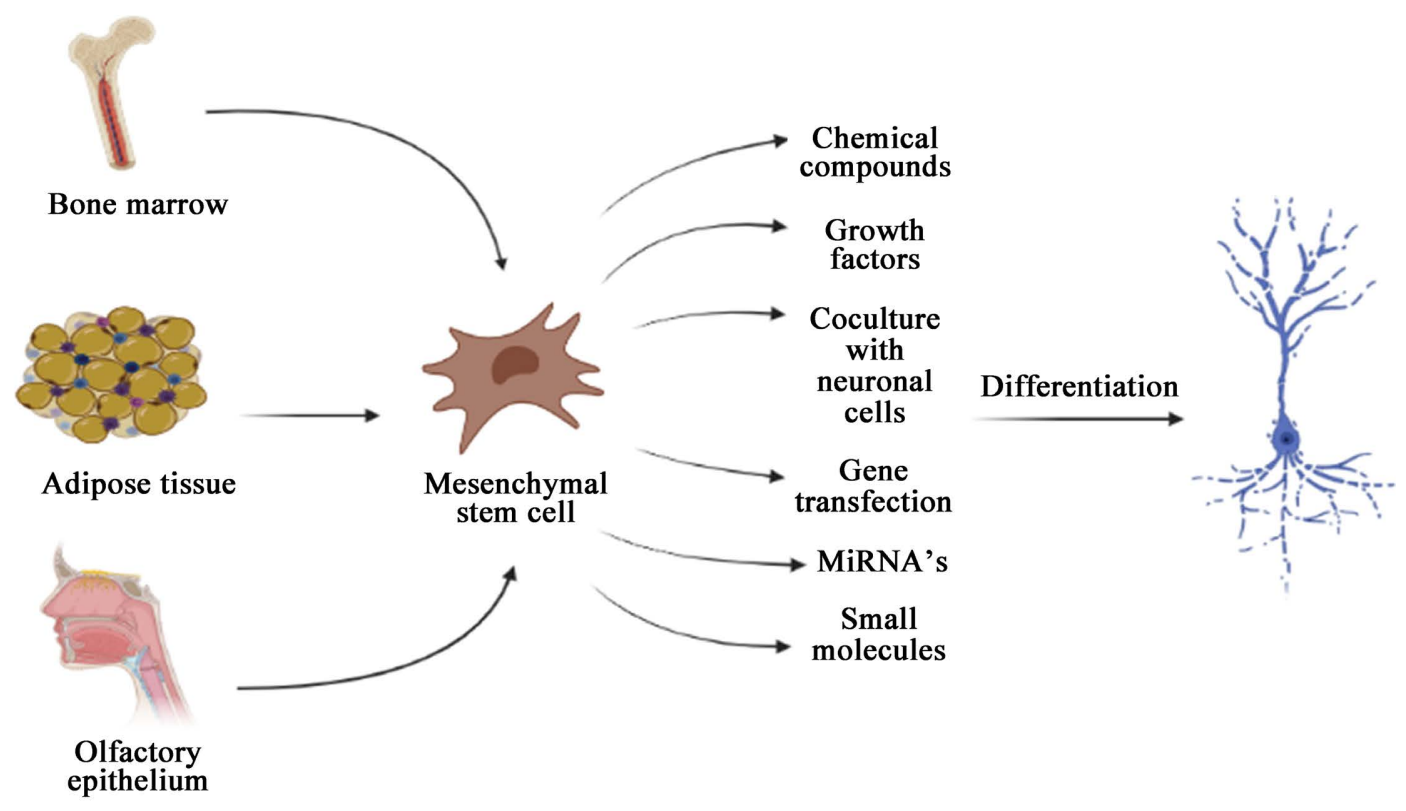

\section{Introduction}

Mesenchymal stem cells (MSC), also known as multipotent mesenchymal stromal cells, are present in almost all postnatal organs and tissues, particularly in the perivascular region [1]. These cells are characterized by a spindle-shaped morphology with an elongated central nucleus and contain 2 to 3 nucleolus. Three subpopulations of these cells have been described by flow cytometry: 1) small fusiform and granular cells, 2) small agranular cells, and 3) large granular cells. By microscopy, two morphological types have been reported in culture, a fibroblastic shape (predominant) and more giant cells with rhomboid shape [2].

According to the International Society of Cell Therapy's Committee on Mesenchymal and Tissue Stem Cells, MSCs must meet three minimum criteria: 1) they must be adherent to plastic under standard growing conditions; 2) must express the CD105, CD73, and CD90 markers (more than 95\% of the cell culture), as measured by flow cytometry, and should lack the expression (less than 5\%) of CD45, CD34, CD14, CD11b, CD79a, CD19, and HLA Class II; and 3) finally, the cells must have the ability to differentiate into osteoblasts, adipocytes, and chondrocytes, using standard conditions for in vitro culture differentiation (Figure 1). Differentiation to osteoblasts can be demonstrated by red alizarin or von Kossa staining; Oil Red staining quickly demonstrates adipocyte differentiation and chondrocyte differentiation, shown by Alcian blue 8G and collagen type II [3].

In theory, mesothermal differentiation is easily achievable for MSC because they have the exact embryonic origin. However, several studies have provided evidence that under optimal in vitro growing conditions or in vivo cardiac niches, MSC may also result in other types of highly specialized tissues, including cardiomyocytes and endothelial cells [4] or endodermal lineages, such as hepatocytes [5] and pancreatic beta cells [6]. In addition, numerous studies have 


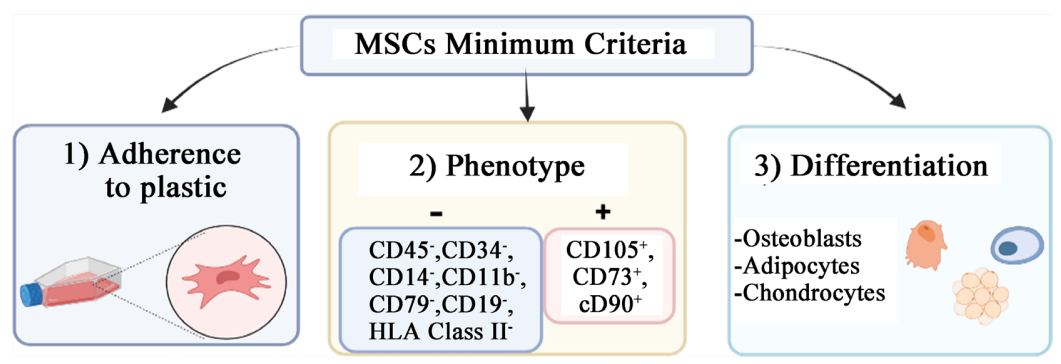

Figure 1. According to the International Society of Cell Therapy's Committee on Mesenchymal and Tissue Stem Cells, minimum criteria to be considered mesenchymal stem cells.

shown that these cells also can differentiate into ectodermal lineages such as nerve tissue [7] [8] [9].

In vitro reprogramming of MSCs towards the neuronal lineage can be carried out using different methodologies with different inducers, such as chemical substances, growth factors, co-cultivation with neural lineage cells, gene transfection miRNA, and chemicals called small molecules. These methodologies show considerable variations in terms of efficiency of differentiation. The choice of the various differentiation inducers depends on several factors, such as the price and the intrinsic characteristics of the cells used to induce the differentiation process. It will depend on the presence or absence of the receptors required by these inducers and on the expression of the molecules involved in the differentiation pathways that the different inducers must specifically activate. Therefore, this article aims to compare multiple experimental tests in which these inducers promote the neuronal differentiation of MSCs. The analysis will identify an optimal neuronal differentiation method with reasonable differentiation rate, maturation, expression of neuronal markers, functionality, and cell survival considering the intrinsic characteristics of the MSCs used as the tissue of origin and the species from which they were isolated.

\section{MSC History}

In 1999 Pittenger et al. characterized an isolated population of homogeneous human mesenchymatous cells derived from bone marrow, highly proliferative in culture, with an extended fibroblastic morphology. These cells showed a constant set of surface proteins expression and high differentiation capacity towards adipocytic, chondrocyte, and osteocytic lineages. All these characteristics were maintained in cell colonies derived from individual cells (clones), avoiding the possibility that the bone marrow contained only progenitor cells committed to the hematopoietic lineage [10].

In addition to bone marrow aspiration, MSC has been isolated from a variety of other adult tissues, such as adipose tissue aspirates and other connective tissues, such as the medullary space of long bones, fragments of trabecular bone, periosteum, synovial fluid, periodontal ligament, palatine amygdala, parathyroid gland, and fallopian tube, pancreas, liver, dermis, and adult skeletal muscle [2] 
[11]. Similarly, MSC can be extracted from other tissues such as Wharton's jelly umbilical cord, temporary tooth pulp, amniotic fluid, amnios, and placenta [11] [12] (Figure 2).

Recently, a population of stem cells with mesenchymal characteristics was isolated from the nasal epithelium. These cells have a cell phenotype characterized by the expression of surface proteins common to MSC, including STRO-1, CD90, CD105, and Nestine, an intermediate filament. They do not express markers typical of the olfactory epithelium, such as cytokeratin's, nor hematopoietic lineages, such as CD34 and CD45. It is important to note that these cells are obtained from lamina propia and differ markedly from the basal cells of the olfactory epithelium, which act as stem cells for the neuroepithelial lineages [13].

Nasal MSC is transcriptionally more related to bone marrow MSC and has shown significant differences with other stem cells such as hematopoietic stem cells, neural progenitor cells, synovial fibroblasts, and periosteum cells. Additionally, nasal MSC shows a high proliferation rate compared to bone marrow MSC, differentiating into bone cells and neurons, and has little differentiation capacity to chondrocytes and adipocytes since chondrogenesis inhibitors (Asporin) adipogenesis (GATA2) are positively regulated. At the same time, neurogenesis (Neurogenesis-1) and osteogenesis (OSR2) activators are overexpressed in these cells. In addition, since nasal MSC originates from tissue derived from the neural crest, they exhibit more significant expression of genes related to neural cells, so they have been referred to as ecto-mesenchymal stem cells (eMSC) [14].

Cultured cells must present similar criteria to be considered as MSC, regardless of the site from which they are obtained; however, some differences have been found regarding the proliferative capacity and expandability among some MSC depending on their origin, for example, bone marrow and adipose tissue MSC have greater culture efficacy than umbilical cord MSC, but the latter has more significant expansion potential compared to other cell sources [15].

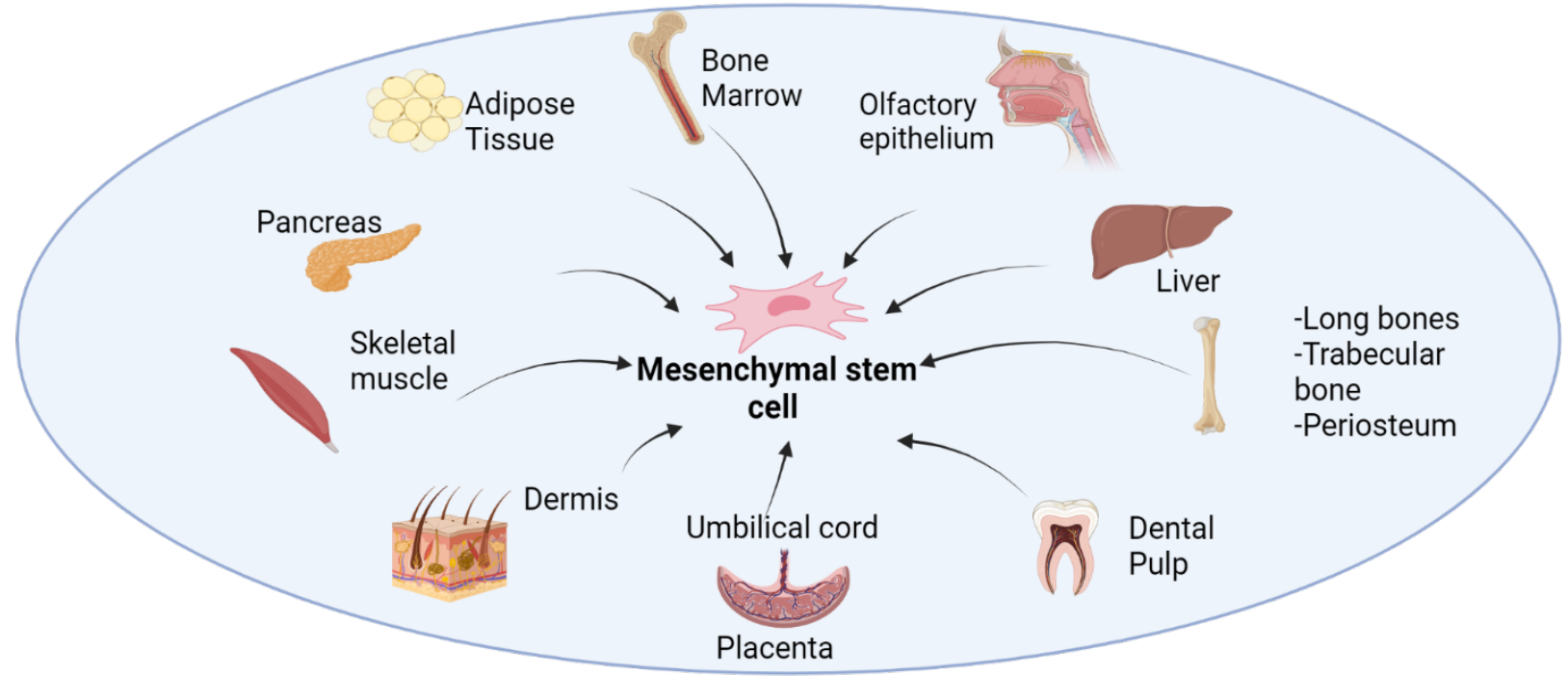

Figure 2. MSCs sources. 


\section{Multipotency of MSC}

The multipotential capability of MSCs, are related to the expression of specific molecules of the mesenchymatous lineage such as vimentin and fibronectin, collagen type I and III, specific factor 2 of osteoblasts, and type VI collagen, and they also express mRNAs common for different kinds of other cell lineages, including osteoblasts, chondrocytes, and myoblasts. In addition to this, the expression of atypical molecules of the mesenchymal cells themselves has also been shown, such as mRNAs characteristic of epithelial and endothelial cells, such as cytokeratin (CK) 8 and 10, vascular endothelial growth factor (EVGF), and collagen IV, among others. MSCs also express transcripts common to neural tissues, such as Neurofilament $\mathrm{H}$, high-affinity nerve growth factor receptor $\left(\mathrm{NGF}^{\text {hi }}\right)$, Nexine 1 alpha, derived from glia, subunit 2C of N-methyl-D-aspartate glutamate receptor, as well as various neurotrophic factors [16]. On the other hand, MSC obtained from fetal tissues has been observed to express genes related to embryonic stem cells, such as the leukemia inhibitor factor receptor (LIFR), ESG1, SOX-2, Oct4, FGFR4, Nanog, Rex1, and TERT, as well as genes for proteins associated with morphogenesis such as $S H H$, Neuregulin1 and 4, Patched, SNA2 and WNT4 [17].

\section{Function and Properties of MSC}

MSCs have remarkable plasticity, allowing them to differentiate to different lineages under the appropriate stimuli. It has been proposed that these cells could function as natural tissue restorers and therefore can be used to restore various cell populations after transplantation. Not only their differentiation potential makes them an ideal candidate for this purpose, but several trophic properties that promote regeneration in the surrounding tissue, including 1) secretion action [17]-[22], 2) migration capacity [23]-[33] and 3) immunomodulatory action [12] [34].

\section{Competitive Advantages of MSC}

Several unique characteristics of adult mesenchymal stem/progenitor cells are essential for therapy. MSC can be stored for long periods without a significant loss of their properties or potency. In addition, it can be collected from a variety of adult tissue, unlike embryonic stem cells, whose use is not aggravated by ethical considerations or legal restrictions. [11]. MSC possesses immune privilege and immunomodulation at every point of the cell cycle. It is propagated to produce the tissue of interest [35] and, most importantly, does not present tumorigenic potential [36]. Likewise, MSC can modulate the immune response since allogeneic transplantation of these cells occurs without a substantial risk of immune rejection, even in the absence of immunosuppressive agents [25]. In addition, MSC has excellent stability after storage, freezing, and thawing do not affect their stemness, nor their cellular properties and functions. And do not induce changes in surface protein expression, activated gene profile, and differen- 
tiation or proliferation capacity [37].

A decisive role in MSCs characteristics is the age and health of the source of these cells. It has been observed that stromal bone marrow cells isolated from healthy individuals under 50 years of age have a higher osteogenic differentiation capacity than cells obtained from individuals over 60 [38]. In addition, for health status, it has been observed that MSC obtained from people with obesity has a significantly deteriorated proliferation and differentiation capacity [39].

\section{MSC and Nervous System Diseases}

Some areas of the brain can grow or deteriorate depending on the cognitive demands from the environment, and acute aggressions can stimulate adult neurogenesis. However, supported by neural stem cell niches, resident progenitor neurons do not compensate entirely for the harmful consequences of severe trauma or neurodegenerative diseases. Therefore, stem cell culture could provide an exogenous cell therapy and be proposed as an attractive alternative to treat various neurological disorders. Several stems or progenitor cells have been proposed to treat brain injuries, such as neural progenitors and embryonic stem cells. However, ethical and technical issues associated with these cells have driven new strategies based on autologous grafting of adult mesenchymal stem cells [30]. MSC can be differentiated into different lineages under the appropriate induction conditions. Therefore, it has been proposed that these cells could restore damaged cell populations after transplantation in nervous system diseases. In fact, not only their differentiation potential makes them an ideal candidate for cell therapy, but the secretion of micro vesicles (exosomes) that promote regeneration in the surrounding tissue is crucial [32].

MSCs must fulfill the following criteria for Cell Therapy Treatment in degenerative neuron diseases: 1) donor cells should be readily available; 2 ) must be highly proliferative with rapid expansion capacity in cell culture; 3) should be immunologically inactive; 4) must survive for a long time and integrate into the host's brain; 5) and should be able to maintain a stable transfection and longterm expression of exogenous genes if that is required for the therapy [27].

MSC has all these characteristics and have become excellent candidates to be applied in cell therapy protocols, demonstrating their usefulness in functional recovery in various models of neurodegenerative diseases and nervous system injuries, like ischemic stroke [18] [30] [40] [41] [42] [43], demyelinating injury [44] [45] [46], spinal cord injury spinal [20] [47] [48] [49], paraplegia [50], Parkinson's disease [17] [51] and cochlear injury [13].

Despite the positive results obtained in these trials using undifferentiated MSCs, some studies suggest that the therapeutic effects obtained by MSC transplantation are potentiated when using differentiated MSCs towards the neuronal lineage before cell transplantation [52] [53]. In this sense, several methods induce in vitro reprogramming of MSCs towards the neuronal lineage. The use of chemical substances, growth factors, co-cultures with neural lineage cells, gene transfection, 


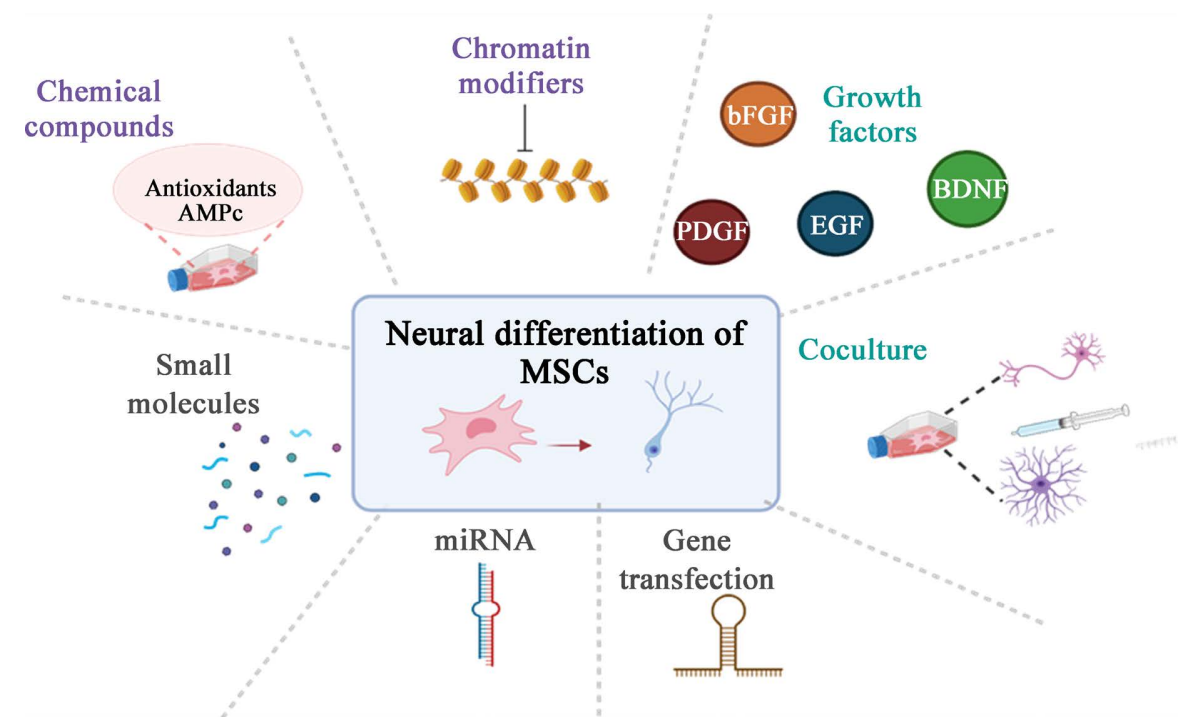

Figure 3. Neuronal differentiation methods for MSCs.

miRNAs, and small molecules (Figure 3).

\section{Chemical Compounds}

Differentiation through chemical compounds has been one of the most used protocols to promote a rapid differentiation of MSCs towards a neural phenotype; within these substances, the use of antioxidants stands out, drugs that increase the levels of cyclic adenosine monophosphate (cAMP) and modifiers chromatin as inducers of transdifferentiation.

\subsection{Antioxidants}

\subsection{1. $\beta$-Mercaptoethanol}

Woodbury et al. were the first to use $\beta$-Mercaptoethanol ( $\beta$-Me) as an inducer in differentiating murine bone marrow MSCs into a neuronal phenotype. For this purpose, the MSCs are exposed to a pre-induction medium with $\beta$-Me at low concentrations for 24 hours to replace this medium later utilizing neuronal induction with a higher chemical concentration. This method promotes that as early as 3 hours after culture in induction medium, the MSCs progressively assume neuronal morphological characteristics. Initially, the cytoplasm of the cells retracts towards the nucleus, forming a contracted multipolar cell body, leaving membranous extensions in the form of peripheral processes. The cell bodies become increasingly spherical and refractile two hours later, exhibiting a typical neuronal appearance, showing primary and secondary branches, growth coneshaped terminal expansions, and putative filopodial extensions. Furthermore, this morphological change is accompanied by an increase in the neuronal marker neuron-specific enolase (NSE) expression in the treated MSCs, compared with control MSCs [54].

In this regard, Zuk et al. treated human MSCs derived from adipose tissue with this protocol, which produced that just 30 minutes after induction, a change 
in the morphology of MSCs was observed, in which around $10 \%$ of the cells assume a neuronal phenotype, which it increases to a maximum of $70 \%$ at 3 hours post-induction. This induction results in the expression of neuronal markers NSE and neuronal nuclear antigen (NeuN) in treated MSCs, the expression of which is not detected in MSCs before treatment. However, the MSCs induced by this protocol do not express mature neuronal markers such as microtubule-associated protein 2 (MAP-2) or neurofilament 70 (NF-70), nor do they express glial markers such as galactosyl ceramidase $(\mathrm{GalC})$ or acidic fibrillar protein of the glia. (GFAP) [55].

This protocol has also been used successfully to differentiate human MSCs derived from bone marrow, finding that 5 hours after adding the antioxidant, changes are observed in the morphology of these cells towards a neuronal morphology. However, after a while, the morphology of these cells returns to its basal condition. This treatment also induces the de novo expression of NF-H in the treated cells and an increase in NSE and NeuN, expressed at deficient levels in control MSCs. Immunohistochemical analysis shows that up to $98 \%$ of the cells stain with antibodies directed against the early neuronal markers NeuN and $\beta$-tubulin III. At the same time, no expression of MAP2, GFAP, or Gal-C is observed, as reported by Zuk and collaborators. The electrophysiological analysis shows the presence of a sodium current $\left(\mathrm{Na}^{+}\right)$, which is inactivated very quickly, and an output current, probably of $\mathrm{K}^{+}$in induced MSCs. Similarly, these cells experience an increase in the intracellular concentration of $\mathrm{Ca}^{2+}$ when challenged with a high concentration of glutamate or potassium $\left(\mathrm{K}^{+}\right)$. At the same time, in undifferentiated MSCs, no significant change is observed in the concentration of this ion [56].

For their part, Khanabdali et al. also reported increases in the expression levels of Nestin, MAP2, and Tau in murine bone marrow MSCs treated with $\beta$-Me, compared to the control group, which expresses these markers at deficient levels. At the same time, positive staining of these cells is observed for Nestin and $\beta$-tubulin III [57].

Finally, Shi et al. demonstrated that using a lower concentration of $\beta$-Me in the induction step does not affect cell differentiation. As early as 5 hours after induction, $70 \%$ of murine bone marrow MSCs treated with half of the concentration of $\beta$-Me used in the previous tests show characteristic morphological changes of neuronal cells. Likewise, an increase in the expression of NSE and Nestin is observed in the induced cells, while the expression of Notch 1 and the downstream Notch gene, Hes1, are reduced after induction. On the other hand, when treating the cells with hydrogen peroxide $\left(\mathrm{H}_{2} \mathrm{O}_{2}\right)$, Notch 1 and Hes1 increase, suggesting that the expression levels of these molecules correlate with changes in the level of reactive oxygen species (ROS), mediated by treatment with $\beta$-Me [7].

\subsubsection{BHA/DMSO}

Woodbury et al. tested the effect of treating pre-induced cells with $\beta$-Me, adding 
dimethyl sulfoxide (DMSO) and butylated hydroxyanisole (BHA) in the induction step. This modification induces neuronal morphological changes with a time course similar to that of $\beta$-Me, where the majority of cells that show rounded cell bodies express high levels of NF-M, tau, and NeuN after exposure to these antioxidants, flat, undifferentiated cells do not. To optimize the differentiation protocol further, the authors replaced the $\beta$-Me in the induction medium with basic fibroblast growth factor (bFGF) and then induced MSCs with DMSO/BHA. It promotes an increase in the proportion of cells with neuronal characteristics since most MSCs treated in this way exhibit neuronal morphologies. Approximately $78 \%$ of the cells stain positively for NSE and 79\% for NF-M [54].

Hou et al. also used DMSO/BHA as inducers to differentiate human MSCs from umbilical cord pretreated with $\beta$-Me. After induction, $70 \%$ of the cells exhibit the neuron-like phenotype, and $71.4 \%$ of all induced MSCs are NSE positive, and $73.2 \%$ for NF. Furthermore, toluidine blue staining indicates the presence of Nissl bodies in the cytoplasm of cells, characteristic of neurons. However, the electrophysiological analysis of these cells does not show the presence of the typical $\mathrm{Na}^{+}$current of the neuron, which suggests differentiation towards an immature neuronal state [58].

For their part, Vaquero et al. studied the effect of adding cerebrospinal fluid before subjecting bone marrow human MSCs to treatment with $\beta$-Me, DMSO, and BHA. The addition of cerebrospinal fluid to the culture medium does not significantly differ in the percentage of cells showing neural differentiation markers. One week after induction, the rate of cells that express neuronal markers is $92 \%$ for NSE, $90 \%$ for NF-200, and $86 \%$ for $\beta$-tubulin III when previously treated with cerebrospinal fluid, versus $90 \%, 86 \%$, and $90 \%$, respectively, when omitting the addition of this [59].

\subsubsection{Tetramethyl Pyrazine}

Nan et al. treated umbilical cord-derived human MSCs with tetramethyl pyrazine, a separate and purified active alkaloid from the Chinese plant Ligusticum wallichii, exhibiting antioxidant properties. After treatment with tetramethyl pyrazine for 30 minutes, $40 \%$ of the cells show neuronal morphology, reaching $85 \%$ after 90 minutes of treatment. RT-PCR analysis shows that these induced cells show NF-H and NSE expression compared to untreated cells. On the other hand, the results of the immunocytochemical staining show that $80.79 \%$ of these cells are positive for NF-H, and 79.76\% are positive for NSE [60] (Supplementary Table S1).

\subsection{Chemicals That Increase cAMP Levels}

Deng et al. treated human bone marrow MSCs with isobutyl methylxanthine (IBMX) and cyclic dibutyryl AMP (dbAMPc), two drugs that increase cAMP levels to induce neuronal differentiation. After six days of induction, approximately $25 \%$ of MSCs differentiate into cells with typical neural morphology and increase the expression levels of NSE and vimentin compared to undifferentiated 
MSCs. However, no changes were observed in the expression level of MAP1B or $\beta$-tubulin III between the two populations. Likewise, after removing the inducers from the culture medium, all neuron-like cells die in the following days [61].

Ashjian et al. induced the neuronal differentiation of CMM when culturing them in an induction medium composed of DMEM medium supplemented with insulin, indomethacin, and IBMX. At 14 days of induction, approximately 25\% of the total MSC population presents a neuronal phenotype with increased expression of NSE, vimentin, Trk-A, and NeuN, which are expressed at low levels in undifferentiated MSC. Furthermore, after 14 days of differentiation, cells expressing neuron-like morphological characteristics show a late rectifying $\mathrm{K}^{+}$ current. However, these cells do not have GFAP or MAP2 and tau [62].

Long et al. evaluated the neuronal differentiation capacity of human bone marrow MSCs by exposing them to dbAMPc and IBMX and growth factors such as epidermal growth factor (EGF), fibroblast growth factor 8 (FGF-8), and brain-derived neurotrophic factor (BDNF). One day after being cultured under these conditions, approximately $30 \%$ of MSCs show neural cell morphology, reaching a value of $70 \%$ by day 6 . On the other hand, the immunohistochemical assay shows that differentiated MSCs stain positively for the markers $\beta$-tubulin III, Nestin, NeuN, NF, gamma-aminobutyric acid (GABA), Tau, and Nurr1, where approximately $90 \%$ of these cells express TUJ1 and Nestin at day 14 of induction. In addition, positivity for GFAP and GalC is observed in some cells with glial morphology [63].

Tio et al. studied the neuronal differentiation capacity of human MSCs obtained from the umbilical cord through treatment with a cytokine induction medium of DMEM with low glucose content. They were supplemented with fetal bovine serum (FBS), IBMX, retinoic acid RA, dbAMPc, nerve growth factor-beta (NGF- $\beta$ ), and bFGF. The addition of the medium generates the appearance of neural-type cells in a percentage of $15 \%$. There is an upregulation in the expression levels of Nurr-1, tyrosine hydroxylase (TH), NSE, NF-H, NF-M, NF-L, and GFAP, compared to undifferentiated MSCs. On the contrary, the expression of dopamine beta-hydroxylase is negatively regulated during differentiation. Immunohistochemistry shows high levels of synaptophysin and phosphorylated TH in differentiated cells. Removal of IBMX and dbAMPc from the medium results in fewer neural-like cells. The individual addition of these components to the growth medium results in the generation of some neuron-like cells [64].

Benítez-King et al. Differentiated human MSCs derived from the olfactory epithelium by culturing them in DMEM/F2 medium supplemented with DbAMPc for $24 \mathrm{~h}$. These molecules induced a decrease in the total number of cells and an increased number of cells carrying bipolar and multipolar neurites. Together, the amount of cells stained with the olfactory neuron-specific anti-OMP antibody increases ten times in the presence of DbAMPc, which exhibits a bipolar morphology, and their soma presents a rounded or ellipsoidal shape, compared to control MSCs [65]. 
In 2016, Shahbazi et al. Evaluated the neuronal differentiation potential of human umbilical cord CMM in the presence of forskolin, another drug that increases levels of CAMP and IBMX. After 8 hours of treatment, morphological changes begin to be observed in some MSCs towards a neural phenotype, which rises $24 \mathrm{~h}$ after the induction process. The immunohistochemical assay and western blot result reveal that Nestin, $\beta$-tubulin III, NSE, and GFAP are positive after eight hours of treatment in the treated cells. In comparison, the expression of MAP2 is appreciated $24 \mathrm{~h}$ post-induction. In contrast, none of these markers are observed in control MSCs. In addition, the combination of forskolin/IBMX improves the phosphorylation of CREB in Ser133, a downstream effector of PKA signaling activated by cAMP, which supports the action of high levels of CAMP in the neuronal differentiation of MSCs [66].

Recently Ayala-Grosso et al. produced neurospheres from human MSCs of the olfactory epithelium by culturing the cells in serum-free DMEM-F12 medium, supplemented with EGF and b-FGF. Subsequently, these mesenchymal neurospheres dissociate into individual cells to differentiate into neuronal lineages on poly-L-lysine-coated coverslips by treatment with RA and forskolin, which generates cells that express the markers $\beta$-tubulin III and GFAP [8] (Supplementary Table S2).

\section{Chromatin Modifiers}

Alexanian et al. treated pre-induced murine bone marrow MSCs with bFGF and EGF, with the hypomethylating agent 5-aza-20-deoxycytidine (5azadC) and the histone deacetylase inhibitor Trichostatin A (TSA) to promote neural induction of these cells. Subsequently, the differentiated cells were cultured in a neural induction medium with or without fixed neuronal stem cells. MSCs treated with epigenetic modifiers exhibit high Sox2 expression compared to untreated cells. In addition, culturing MSCs with neuronal stem cells produces groups or structures similar to neurospheres positive for Sox 2 and Nestin, which are enhanced by pretreating the cells with chromatin modifiers. Finally, the results show that MSCs that are preliminarily treated with 5azadC and TSA produces immunopositive cells for $\beta$-tubulin III and GFAP with certain similarity to neuronal and glial morphology when maintained in a neurobasal environment, where approximately $70 \%$ of the cells show a neuronal morphology [67].

In 2010, this working group induced neuronal differentiation of human bone marrow MSCs by simultaneously exposing cells to DNA methylation inhibitors (RG-108), histone deacetylation inhibitors (TSA). These pharmacological agents increase cAMP (8-BrAMPc and rolipram) and bFGF. Real-time RT-PCR studies show that $24 \mathrm{~h}$ after treatment, the expression level of genes associated with Oct 4 pluripotency, Nanog, Klf4, c Myc, and Sox 2 increase in treated MSCs Likewise, the expression levels of the neural genes Nestin, A2B5, NCAM, GFAP, NeuN, MAP2, Nurr1, and TH gradually increase in these cells during the differentiation process. Likewise, these cells can release glial-derived neurotropic factor 
(GDNF), BDNF, and dopamine to the medium after induction [68].

Two years later, this working group demonstrated that human bone marrow MSCs subjected to hypoxic preconditioning and differentiated by the previous protocol show an improvement in their dopaminergic differentiation since the expression levels of Nurr1 and TH increase significantly in induced MSCs. They were grown under hypoxic conditions, while its counterpart grew under normal oxygen conditions. Likewise, the cell proliferation assay results show that hypoxic preconditioning improves the proliferation and viability of MSCs by protecting them from the cytotoxic effect of $\mathrm{H}_{2} \mathrm{O}_{2}$. On the other hand, ELISA studies show that the release of BDNF, GDNF, and dopamine in the treated MSCs is enhanced by cultivating the cells in conditions with low oxygen levels [69].

Zheng et al. compared the differentiation potential of murine MSCs from bone marrow and adipose tissue under these differentiation conditions. MSCs from adipose tissue exhibit a greater proliferation capacity than bone marrow MSCs in vitro. After a seven-day neuronal induction period of $73.61 \%$ of MSCs derived from bone marrow present a neuronal morphology cell, while using adipose MSCs, $93.01 \%$ of these cells were observed. Furthermore, after treatment, more cells positive for $\beta$-tubulin III and ChAT is found in the culture of treated MSCs derived from adipose tissue, relative to bone marrow MSCs. However, a more significant number of MAP2 positive cells is observed when using bone marrow MSCs. In addition, the RT-PCR and ELISA results show a greater expression and release of BDNF but less of NGF and neurotrophin 3 (NT-3) in differentiated bone marrow MSCs compared to those of adipose origin [70].

For their part, Nivet et al. Treated adipose tissue human MSCs with 5-azacytidine, NGF, BDNF, and bFGF to induce their neuronal differentiation. After induction, MSCs show changes in cell morphology, which persist for up to 2 weeks in a neurobasal environment. Specifically, the cytoplasm of some cells retracts toward the nucleus, forming contracted cell bodies with extended cytoplasmic extensions. Increases in Nestin expression accompany these morphological changes and de novo expression of MAP2 and NSE compared to control MSCs. On the other hand, the quantitative analysis shows that one week after neuronal induction, $85.6 \%$ of the treated MSCs stain positively for GFAP, while $81.2 \%$ do so for MAP2 [30].

Recently in 2017, Fila-Danilow et al., Analyzed the role of histone deacetylase inhibitors TSA and valproic acid in the neuronal differentiation of murine MSCs pretreated with bFGF and EGF. They find that the expression of $\beta$-tubulin III and Gal-C increases after three days of treatment in MSCs but decreases after six days. On the contrary, the expression of $\mathrm{TH}$ and VAChT increases gradually in these cells during the differentiation process [71] (Supplementary Table S3).

\section{Growth Factors}

Goodwin et al. treated human MSCs of the umbilical cord and bone marrow in a medium added with bFGF and EGF for seven days for their neuronal differen- 
tiation. After treatment, both the umbilical cord and bone marrow MSCs morphologically adopt some of the characteristics of neural cells in culture, such as long bipolar extensions and branched ends. Furthermore, both cell populations express $\beta$-tubulin III and GFAP after induction. However, umbilical cord MSCs express the markers only after the differentiation process, whereas some bone marrow MSCs already express these markers constitutively in the standard growth medium but increase their expression with the addition of the growth factors [72].

Dezawa et al. used a combination of growth factors to differentiate murine bone marrow MSCs, for which they first pre-induced these cells by treating them with $\beta$-Me and RA for three days. Later they were cultured in an alpha-MEM induction medium supplemented with FBS, Forskolin, bFGF, platelet-derived growth factor (PDGF), and recombinant human Heregulin betal (HRG) for seven days. Phase-contrast microscopy reveals that MSCs adopt a morphology similar to Schwann cells after differentiation, unlike control MSCs. Immunohistochemistry shows that most differentiated MSCs, but not the undifferentiated ones, are positive for the Schwann cell markers p75, S100, GFAP, and O4. On the contrary, the omission of $\beta$-Me, RA, forskolin, or HRG in the differentiation protocol results in incomplete differentiation of MSCs in both morphology and immunoreactivity [52].

Peng et al. used this same protocol to induce neural differentiation of human MSCs derived from Wharton's jelly. After induction, these cells change from a flat shape to a bipolar spindle morphology and express Schwann cell markers. Cell quantification shows that approximately $68 \%$ of the differentiated cells are positive for GFAP, 77\% for $\mathrm{p} 75,75 \%$ for $\mathrm{S} 100$, and $72 \%$ for MBP. Furthermore, the enzyme-linked immunosorbent assay and RT-PCR show that differentiated MSCs express and secrete BDNF, NGF, and NT-3 into the medium [73].

For their part, Jiang et al. cultured bone marrow murine MSCs in wells coated with fibronectin and bFGF to induce their neuronal differentiation. After 14 days of induction, MSCs acquire morphological and phenotypic characteristics of neuronal and glial cells, defined by their positivity for NF200 (68.9\%), GFAP (15.4\%), and Gal-C (12.3\%). Following bFGF culture, the messenger RNA levels of Otx2, Otx1, Pax2, Pax5, Nestin, MAP2, and Tau are significantly increased compared to undifferentiated MSCs. On the other hand, when MSCs are cultured sequentially with bFGF, FGF-8, and finally BDNF, a more mature neuronal phenotype is observed since approximately $30 \%$ of the cells express markers of dopaminergic neurons, $20 \%$ of serotonergic neurons, and $50 \%$ of GABAergic neurons [74].

Jin et al. treated murine bone marrow MSCs with neurobasal medium supplemented with B27, glutaMAX, FGF-2, and EGF for seven days and subsequently added RA and $\beta$-NGF to the medium for four weeks to induce neural differentiation. This protocol promotes that the treated cells acquire a neuronlike polar morphology. Most of these cells express the mature neuronal markers 
NeuN and MAP2, and some the microtubule-associated protein tau. Furthermore, cells in these cultures express $\alpha 1 \mathrm{~A}$ and $\alpha 1 \mathrm{~B}$ calcium channel subunits associated with neuronal calcium channels and the protein synaptophysin. Finally, many differentiated MSCs stain positively for GABA and the NR2A subunit of the glutamate NMDA receptor [75].

Tropel et al. used a one-step protocol to differentiate murine MSCs in neurons. Cells were seeded on plates coated with poly-D-lysine and cultured for seven days in DMEM medium supplemented with bFGF. Tow days after the addition of the growth factor, some short neurite-like extensions are observed in MSCs, which fully develop after one week, where the cells acquire a neuron-like morphology. However, the cells revert to a fibroblast shape after a few days. Immunostaining shows that approximately $50 \%$ of undifferentiated cells express Nestin, 12.4\% NF-L, and 2\% $\beta$-tubulin III, while treatment for one week with bFGF dramatically increases the number of positive cells to $94.5 \%$., $88.5 \%$ and $65 \%$, respectively. In addition, this expression of neural markers is combined with a functional acquisition of neurons, such as an increase in the concentration of cytosolic calcium in response to specific neuronal agonists such as glutamate and veratridine [76].

In 2007 Trzaska et al. used an induction cocktail consisting of SHH, FGF8, and bFGF, to promote neuronal differentiation of bone marrow-derived human MSCs. 12 days after exposure to these factors, MSCs develop a characteristic neuronal morphology and an increase in the expression of neuronal markers NeuN, B-tubulin III, TH, DAT, En1, En2, Wnt1, Lmx1a, Nurr1, and Pitx3, but not glial markers compared to untreated MSCs. Likewise, as cells acquire a postmitotic neuronal fate, the expression of the cell cycle activating proteins cyclin B, cyclin-dependent kinase 2, and the nuclear antigen of the proliferating cell is negatively regulated. The neuronal characteristics of the induced MSCs were confirmed by the expression of the ion channel genes of $\mathrm{K}^{+}(\mathrm{Kv} 4.2)$ and voltage-gated $\mathrm{Na}^{+}(\mathrm{NaV})$. Quantitative analyzes indicate that more than $90 \%$ of the treated MSCs express NeuN and $\beta$-tubulin III, while $68.7 \%$ of these cells were $\mathrm{TH}$ positive. Likewise, these cells are capable of synthesizing and secreting dopamine into the environment independently of depolarization. Electrophysiological analysis shows that these cells have a resting membrane potential ranging from $-50 \mathrm{mV}$ to $-70 \mathrm{mV}$. However, none of the cells exhibit spontaneous and evoked action potentials. Additionally, although MSC-derived neuron-like cells express functional $\mathrm{K}^{+}$channels, they express deficient levels of voltage-gated $\mathrm{Na}^{+}$ and $\mathrm{Ca}^{2+}$ channels, suggesting that SHH, FGF8, and bFGF-induced MSCs produce Dopaminergic cells that have not acquired the properties of completely differentiated neurons [77].

In 2011 Datta et al. used this induction protocol to differentiate human MSCs from the umbilical cord and bone marrow. Finding that after exposure to $\mathrm{SHH}$, FGF8, and bFGF, MSCs from both sources change morphologically towards neuron-like cells, which upregulate the expression of $\beta$-tubulin III, Nurr1, and 
EN1, while reducing the expression of Nestine, without presenting significant differences between them. Immunohistochemistry reveals that these differentiated cells are positive for the neuronal markers $\beta$-tubulin III, Map2ab, and Kv4.2 and the specific markers of dopaminergic neurons TH DARPP32, Nurr1, PitX3, and VMAT2. At the same time, the MSCs Untreated do not exhibit any appreciable staining for these markers. Cellular quantification shows that $91.4 \%$ of induced bone marrow MSCs and 91.84\% of umbilical cord MSCs are positive for the mature neuronal marker Map2ab, 63.98\%, and 65.82\% for TH and $62.38 \%$ and $68.90 \%$ for Nurr1, respectively. For its part, the functional analysis shows that cells induced from both sources release dopamine constitutively, unlike untreated MSCs. ATP stimulation promotes an increase in the release of this neurotransmitter in induced MSCs regardless of its origin [78].

For its part, treatment of human MSCs derived from dental pulp with these factors for three days and subsequent maintenance in a neurobasal medium supplemented with B27 and BDNF without morphogens for six days generates a neuronal-type morphological change in MSCs, thus as a positive regulation in the expression of the specific transcription factors of dopaminergic neurons Nurr1, Engrailed 1 and Pitx3, as well as a decrease in the expression of Nestin, musashi12, and HNK1. Immunofluorescence and flow cytometry analysis shows a higher number of cells positive for dopaminergic neuronal markers in induced MSCs with almost 77\% of MSCs positive for TH, 81.92\% for En1, $81.21 \%$ for Nurr1, and $77.87 \%$ for Pitx3. For their part, functional studies indicate that induced MSCs constitutively secrete dopamine and after stimulation with $\mathrm{KCl}$ and ATP. At the same time, untreated MSCs do not show any appreciable release of this neurotransmitter. Furthermore, induced MSCs showed an influx of intracellular $\mathrm{Ca}^{2+}$ in the presence of $\mathrm{KCl}$, which is not observed in untreated MSCs [79].

Wang et al. used a cocktail of SHH, FGF-8, GDNF, and forskolin to induce neuronal differentiation of human MSCs derived from dental pulp pre-induced with bFGF and EGF. After adding bFGF and EGF, the cells are grouped into spheres containing positive Nestin progenitors and neuronal cells positive for $\beta$-tubulin III but negative for TH. Once the inducers are added to the cultures, some neuron-like cells are generated with multiple neurites expressing $\beta$-tubulin III and MAP2. Approximately $10 \%$ of the cells stain positively for TH. Real-time RT-PCR analysis indicates that when MSCs are cultured in the induction medium, the transcription levels of Nestin and $\beta$-tubulin III are down-regulated compared to uninduced MSCs, whereas a significant increase in transcription levels of MAP2 and TH. Furthermore, as tested by liquid chromatography, it is possible to detect the presence of dopamine in the supernatant of the MSC culture after induction. At the same time, this neurotransmitter is not seen in the supernatant of the non-induced MSCs or spheres [80].

Wang et al. incubated murine bone marrow MSCs with tricyclodecan-9-y-1xanthogenate (D609), a specific inhibitor of phosphatidylcholine-specific phos- 
pholipase C, with or without FGF-2 for two days and maintained the neuronal status of these cells when cultured with FGF-2 for six additional days. The tests show that cell viability increases, and the apoptotic index are significantly lower in cells treated with FGF-2 than those without FGF-2 at $48 \mathrm{~h}$. During the next six days, the differentiated cells show typical neuronal morphology in the presence of FGF-2. However, the number of differentiated cells decreases, and many die without this growth factor. The immunohistochemical assay shows that these cells induced with D609 and FGF-2 show strong positive signals for NSE, NF-L, and synapsin and high mRNA expression levels of NSE and NF-L, compared to undifferentiated MSCs. Likewise, after induction for $48 \mathrm{~h}$, the differentiated cells have a lower membrane potential compared to the undifferentiated MSCs, which becomes more negative when the cells are subsequently cultured with FGF-2 for six days. Neuronal differentiation is accompanied by a significant increase in the change in mitochondrial membrane potential, indicative of mitochondrial hyperpolarization, and a decrease in ROS levels after 6 hours in the group treated with D609 and FGF-2 [81].

Marei et al. Treated adipose tissue human MSCs with FGF2 and heparin for 15 days to induce their neuronal differentiation. This protocol promotes changes in the cell morphology of spindle-shaped MSCs towards cells with spherical morphology and cellular processes. On the other hand, the transcriptional analysis shows that the expression levels of $\beta$-tubulin III, MAP2, ChAT, and TH are positively regulated in the induced MSCs compared to the control cells [82].

Mareschi et al. used human MSCs from amniotic fluid to evaluate their neuronal differentiation by culturing them with FGF, EGF, and neural survival factor (NSF-1), for three weeks. Under these conditions, cells aggregate into spheres suspended in the medium, and then adherent clumps form, with cells showing prominent processes that slowly increase during treatment with growth factors. Neurospheres-like floating pools analyzed after three days of culture are positive for Nestin, while cytokeratin expression remains negative and vimentin expression decreases compared to untreated cells. Likewise, neuronal induction increases the expression of neuronal markers in MSCs. In particular, positivity for NSE and MAP2 is observed in $80 \%$ of cells. Electrophysiological analyses show that undifferentiated MSCs present transient $\mathrm{Na}^{+}$entry currents sensitive to tetrodotoxin (TTX) and that treatment with growth factors promote an increase of approximately three times the density of these currents. Likewise, an increase in the expression of the $\mathrm{Na}^{+}$channel subunits is found in differentiated cells, compared to untreated MSCs [83].

Jang et al. cultured human MSCs isolated from adipose tissue in DMEM medium supplemented with bFGF for seven days, accompanied by the addition of forskolin for an additional seven days to induce their neuronal differentiation. After treatment, most MSCs exhibit distinct bipolar or multipolar morphologies with branching processes, visualized by the immunocytochemistry of the somatodendritic marker, MAP2, and the axonal marker, GAP43. In addition, in neu- 
rally differentiated MSCs, immunoreactivity is observed for markers of neural stem cells (Nestin), neuronal (Tuj1, MAP2, NFL, NFM, NFH, NSE, and NeuN), synaptic (GAP43 and SNAP25), astrocytic (GFAP) and Oligodendrocytes (CNPases) very high when cultured in the presence of bFGF and forskolin, while the portion of undifferentiated MSCs expressing specific markers is very low. The RT-PCR analysis shows mRNA levels encoding ABCG2, Nestin, Tuj1, MAP2, NFL, NFM, NSE, GAP43, SNAP25, GFAP, and CNPase upregulated in differentiated MSCs. The functional analysis of these cells shows that more than $75 \%$ of the differentiated MSCs acquire functions similar to neurons characterized by the visualization of voltage-dependent sodium currents sensitive to TTX, outward $\mathrm{K}^{+}$currents, and negative resting membrane potentials. A more detailed examination by RT-PCR shows that undifferentiated MSCs expression channel genes for sodium (SCN5A), potassium (MaxiK, Kv4.2, and EAG2), and calcium channels (CACNA1C and CACNA1G), which are significantly increased by inducing differentiation in these cells. In contrast, the Kv4.3 and Eag1 potassium channel genes and the TTX-sensitive sodium channel gene are only expressed in cells subjected to the differentiation protocol [84].

Ying et al. promoted the neuronal differentiation of murine MSCs from adipose tissue by preincubating these cells in a DMEM medium, supplemented with EGF, bFGF, and BDNF for three days. The subsequent addition of indomethacin, insulin, and IBMX for $48 \mathrm{~h}$ for their induction. After treatment, MSCs show changes in cell morphology, including cytoplasmic contraction, axon formation, dendrite-like cytoplasmic projections, and express neuronal and glial markers Tuj-1 and GFAP, respectively, which are extremely low before induction. Quantitative analysis indicates that approximately $70 \%$ of the induced cells are positive for Tuj1, and 75\% are positive for GFAP. However, the absence of BDNF in pre-induction reduces the number of positive cells for these markers to $45 \%$ and $50 \%$, respectively [9].

In 2014, Feng and collaborators planted adipose tissue-derived human MSCs in gelatin-coated plates. For neuronal differentiation, cells were pre-induced with $\beta$-Me and bFGF for eight days. Subsequently, culture in a DMEM/F12 medium supplemented with L-glutamine, B27, N2, and $\beta$-Me for seven days, to finally treat them with EGF and bFGF for an additional seven days. MSCs subjected to this protocol exhibit distinct morphologies similar to neuronal stem cells, which can easily detach from the background after digestion and merge to form neurospheres when cultured in ultra-shallow dishes. Furthermore, these cells cultured as monolayer or neurospheres highly express Sox1, Pax6, Nestin, and Vimentin, compared to undifferentiated cells. Subsequently, they tested the terminal differentiation capacity of the cells subjected to this protocol by seeding the cells on coverslips covered with poly-D-lysine and laminin in a Neurobasal medium supplemented with N2, FBS, horse serum, and RA for two weeks, with the subsequent administration of BDNF for neuronal induction. After two weeks of induction, cells cultured in a neuron induction medium show a similar struc- 
ture to neurons and MAP2 expression. These cells exhibit a TTX-sensitive voltage-dependent sodium current, exhibiting a rapid on-off characteristic. In addition, the expression of the sodium ion channel genes (SN5A, NE-NA), the potassium ion channel genes (MaxiK, KV4.3, KV4.2, KV1.4, EAG1, EAG1), and calcium ion channel genes (CACNA1C, CACNA1G) are increased in terminally differentiated MSCs compared to undifferentiated MSCs [85].

In that same year, $\mathrm{Yu}$ et al. compared the neuronal differentiation capacity of human MSCs obtained from adipose tissue, bone marrow, and umbilical cord when cultured in the presence of BDNF. After seven days of induction, human MSCs assume a neuron-like morphology regardless of the acquisition site, while control MSCs retain fibroblast morphology. Likewise, all the MSC groups treated with BDNF show higher levels of Nestin expression than the control groups, without significant differences between them. On the other hand, a higher expression of ChAT and GAD67 is observed in the induced bone marrow and umbilical cord MSCs compared to control MSCs, and adipose tissue induced MSCs. Exposure to BDNF appears to promote GABAergic neuronal differentiation since an increase in the percentages of $\mathrm{GABA}^{+} / \mathrm{DAPI}^{+}$cells is observed in treated MSCs, compared to control cultures in adipose tissue MSCs (9.7\% vs. 5.3\%), bone marrow ( $21.5 \%$ vs $8.4 \%)$ and umbilical cord $(7.0 \%$ vs $1.8 \%)$, respectively [86].

Recently Jahan et al. studied the neuronal differentiation of umbilical cordderived human MSCs by treating them with NGF. 4 days after the addition of this growth factor, morphological changes similar to the neuronal type are observed, such as rounding of cells and the development of neurite-like extensions. These neuron-like cells show a significant and gradual increase at the messenger and protein level of the neuronal markers NF-M, $\beta$-tubulin III, and PSD-95 compared to undifferentiated MSCs [87] (Supplementary Table S4).

\section{Coculture}

Sánchez-Ramos et al. carried out the coculture of MSCs previously differentiated by RA and BDNF with fetal primary neuronal cultures to increase the neuronal differentiation of these cells. After co-cultivation, $2 \%-5 \% \beta$-galactosidase-labeled MSCs stain positively for NeuN, and $5 \%$ to $8 \%$ do so for GFAP, a much higher proportion than observed when the MSCs are cultured alone. Most $\mathrm{GFAP}^{+}$cells labeled with $\beta$-galactosidase have an oval or spindle-shaped morphology with short processes similar to those of $\mathrm{NeuN}^{+}$cells. However, some $\mathrm{GFAP}^{+}$cells show an irregular shape that approximates the morphology of glial cells [88].

Joannides et al. induced neuronal differentiation of bone marrow-derived human MSCs by exposure to EGF and FGF-2 for seven days, followed by treatment with postnatal astrocyte conditioned medium derived from rat hippocampal cultures. Twenty-four hours after the addition of mitogens, morphological changes characterized by cell retraction are observed. At the same time, at the end of 7 days of induction, the co-expression of the neural markers $\beta$-tubulin III and pan- 
neurofilament is evident in the soma of a subpopulation of rounded cells. Upon removal of mitogens, the expression of these markers is significantly reduced with an associated increase in cells expressing smooth muscle actin co-localized with FN. However, treating differentiated cells with an astrocyte-conditioned medium promotes an increase in the number of cells expressing neurofilament and $\beta$-tubulin III compared to treatment without the conditioned medium and down-regulation fibronectin in these cells. Furthermore, these positive $\beta$-tubulin III cells show greater elaboration of processes than cells that are only treated with mitogens [89].

Fu et al. use umbilical cord-derived human MSCs in a neuron-conditioned medium, observing that MSCs acquire a neuronal-like morphology on day 12. The processes generated in the MSCs are excessively long and form cell-cell contacts, creating a network's appearance. Likewise, these neuron-like cells show an increase in the expression of NeuN and NF compared to the untreated MSCs. The quantitative study reveals that on the ninth day of coculture, $58.2 \%$ and $87.4 \%$ of MSCs stain positively for the neuronal markers NeuN and NF, respectively. In comparison, only $1.95 \%$ and $1.77 \%$ do so for GFAP and OX42, respectively. Furthermore, treatment with the conditioned medium induces in some MSCs the expression of functional calcium-binding proteins, such as parvalbumin and calbindin. Finally, the kainate receptor subunits, including GluR6, GluR7, and KA2, begin to appear in small amounts in MSCs after coculture for six days, and the labeling becomes significant after 12 days, allowing these cells to respond to a glutamate bath, generating input currents [90].

This working group induced human MSCs isolated from Wharton's gelatin to transform into dopaminergic neurons in vitro by treatment with the neuronconditioned medium for nine days, with subsequent exposure to SHH and FGF8 for an additional 12 days. Immunocytochemical staining shows that MSCs treated with this protocol are $\mathrm{TH}$ positive with a success rate of $12.7 \%$, capable of synthesizing and releasing dopamine to the culture medium. On the other hand, staining for the enzyme glutamic acid decarboxylase indicates that MSCs exposed to conditioned medium and morphogens differentiate, in addition to dopaminergic neurons, in low yields of GABAergic cells [91].

Zurita et al. compared the differentiation efficiency of murine bone marrow MSCs employing a chemical protocol based on the use of $\beta$-Me as pre-inducer and DMSO, $\mathrm{BHA}, \mathrm{KCl}$, valproic acid, and forskolin as inducing agents, with a method based on co-culture of the MSC with Schwann cells. One hour after starting the chemical induction, approximately $30 \%$ of MSCs show positivity for Nestin, this percentage increasing at four $\mathrm{h}(64 \%)$ while showing morphological changes related to neuronal cells. One week after starting the chemical induction, positivity for NSE is found in $79.9 \%$ of MSCs, while $85.3 \%$ show positivity for NF-200 and $86.2 \%$ for $\beta$-tubulin III. For its part, it is observed that co-culture induces late neuronal differentiation since, although MSCs begin to express Nestin $4 \mathrm{~h}$ after coculture, most MSCs need approximately one week to show typical 
neuronal morphology. However, by this time, the neuron-like cells no longer expressed Nestin but showed positivity for NSE (60\%), NF-200 (52\%), and $\beta$ tubulin III (34\%) [92].

Since cell fusion cannot be excluded as the cause of apparent transdifferentiation of MSCs cultured in Schwann cells, these authors carried out co-cultures of bone marrow MSCs and Schwann cells in the presence of polycarbonate membranes to prevent direct contact between these cells. Under these conditions, MSCs express Nestin $4 \mathrm{~h}$ after starting the cocultures. A strong expression of neuronal markers such as NF-200, $\beta$-tubulin III, or GFAP is revealed at $72 \mathrm{~h}$, increasing during the second week of treatment. At the end of the second week, most MSCs show clear neuronal morphology, and around $9 \%$ of MSCs show positivity for Nestin, $39 \%$ for NF-200, and $43.2 \%$ for $\beta$-tubulin III, while only $20.4 \%$ of cells are positive for GFAP [93].

For their part, Krampera et al., Cocultivated MSCs of different origins with Schwann cells to induce their neuronal differentiation. After 12 days of coculture, a proportion of MSCs acquires the morphological characteristics of Schwann cells and a selective expression of the markers S-100 and PMP-22. The ratio of these cells depends on the origin of the MSCs. MSCs derived from adipose tissue show the highest percentage of cells that acquire the Schwann cell phenotype after seven days of coculture. This proportion is significantly lower than the use MSCs of the thymus, spleen, and particularly bone marrow. On the other hand, in this study, it is observed that direct contact between the Schwann cells and the MSCs is necessary to induce the morphological and phenotypic changes of the MSCs, since the treatment of the MSCs with the cell culture supernatant Schwann's does not generate the effects above. Finally, Kamprera et al. show that irradiation of Schwann cells before coculture does not change the proportion of differentiated MSCs, thus ruling out an essential role of cell fusion in expressing glial markers by MSCs [94].

Wislet et al. generated Nestin-positive murine bone marrow MSCs by EGF treatment. Subsequently, Nestin positive MSCs were co-cultured in a conditioned medium with neurons from mouse cerebellar granules to induce their terminal differentiation. After five days of coculture, $40.17 \%$ of the MSCs stain positively for GFAP, 19\% for Tuj1, and 19.30\% for NeuN. However, these neuronal markers cannot be detected when coculturing Nestin negative MSCs or Nestin positive MSCs, cultured physically spaced neurons. Electrophysiological assays show that neuron-like cells have a resting membrane potential of $-55.7 \mathrm{mV}$ at ten days of coculture and that these cells express functional voltage-gated $\mathrm{K}^{+}$channels in the early stages of differentiation, followed by the presence of voltage-gated $\mathrm{Na}^{+}$ channels, which allows them to trigger action potentials, unlike control MSCs. Finally, it was shown that these differentiated cells could respond to various neurotransmitters such as GABA, glycine, and glutamate by evoking electrical currents that are reversibly blocked by specific antagonists of their respective receptors [95]. 
Nivet et al. demonstrated that coculturing human MSCs from the olfactory epithelium with mouse hippocampal slices provides a suitable environment for the in vitro neuronal differentiation of these cells, since three weeks after engraftment, surviving MSCs are observed on top of organotypic cultures of the hippocampus, where some of them show a morphology similar to an interneuron with the expression of MAP2, but not GFAP [30].

Recently, Lo Furno et al. induced neuronal differentiation of human MSCs from adipose tissue by treating them for seven days with a conditioned medium obtained from cultures of olfactory envelope cells or Schwann cells. MSCs grown under these conditions have a more complex morphology than MSCs grown alone. Likewise, these cells have a higher immunoreactivity for Nestin, MAP2, and Synapsin than control MSCs. In particular, a more pronounced increase in MAP 2 positivity is detected when using the olfactory envelope cell-conditioned medium relative to the Schwann cell-conditioned medium. To glial differentiation, the immunopositivity of GFAP is relatively low in controls but is markedly increased in cells treated with the conditioned medium, especially when using a medium derived from Schwann cells [96].

Finally, in 2019, Wei et al. cultured bone marrow-derived murine MSCs with Schwann cell-conditioned medium to induce neuronal differentiation. Upon treatment with the medium, the shape of the MSCs changes to a neuronal-like morphology as cell bodies gradually shrink and neurites form. Furthermore, an increase in Nestin and MAP2 markers are detected in neuron-like cells. The microRNA analysis identifies 83 microRNAs significantly differentially expressed between the co-cultured group and the control group, where the Gene Ontology analysis indicates the enrichment of microRNA target genes for the development of neuronal projection, the regulation of axon genesis, and the positive regulation of proliferation in MSCs cultured with the conditioned medium. Furthermore, the analysis of the KEGG pathway shows that the Hippo, Wnt, and SHH signaling pathways are potentially associated with the neuronal differentiation of MSCs treated with this medium [97] (Supplementary Table S5).

\section{Gene Transfection}

A small interfering RNA (siRNA) directed against notch-1 (mNotch-1shRNA) was transfected into CMM. Its neuronal differentiation was induced when cultured in a Neurobasal medium supplemented with RA and BDNF for six days. After $24 \mathrm{~h}$ of transfection, the MTT assay values of mRNA Notch-1 in MSCs decrease and are much lower than those of non-transfected MSCs. Likewise, there are more apoptotic cells in the transfected MSCs than in the control CMM. On the other hand, the transfection of mNotch-1shRNA alone is not enough to induce the differentiation of MSCs in neural cells. However, after induction with RA and BDNF, the transfected MSCs undergo a remarkable morphological change, where $24 \mathrm{~h}$ after induction, the cytoplasm of these cells retracts and presents extensions in the form of processes, which improves during the following six days. 
Likewise, the expression of NSE and NF200 increases to high levels in the mNotch-1shRNA MSCs after induction. In contrast, the expression of GFAP decreases in this group compared to the induced MSCs without transfection [98].

In 2008, Trzaska et al. Sought to improve the neuronal differentiation obtained in 2007, transfecting an RNAip directed to REST, a transcriptional regulator that silences the expression of specific genes of mature neurons in non-neuronal cells and neuronal progenitors, before undergoing the differentiation with $\mathrm{SHH}$, FGF-8, and bFGF. The bright-field images taken on days 6 and 12 of induction show a more mature phenotype in REST knockdown cells compared to control transfected cells. Furthermore, the loss of the REST protein allows a higher expression of TH, NeuN, Pitx3, and Nurr1 and an increase in $\mathrm{NaV}$ protein levels in neuronal cells derived from MSCs. On the other hand, the electrophysiological tests show that the induction at day 12 in MSCs with a drop in REST generates the presence of spontaneous solid discharges and postsynaptic currents compared with the control cells [99].

Yang et al. used lentiviral vectors to deliver siRNA against REST1 (siREST) or negative control (siControl) to differentiate bone marrow human MSCs into a neuronal phenotype. Fourteen days after transfection, most siREST MSCs exhibit a neuron-like morphological change, with structures equivalent to long neurites and Nissl bodies, but not in siControl MSCs. Cell proliferation analysis shows that MSC-siREST grows slower than MSC-siControl, suggesting that MSCsiREST is in a differentiation stage. The RT-PCR analysis shows that at 14 days of transfection, the MSC-siREST increases the expression levels of neuronal genes BDNF, NGN-1, NSE, SYP, and SCG10 while the expression of these genes does not it is detectable in the CMM-siControl. Likewise, these cells stain positively for $\beta$-tubulin III, NSE, MAP-2, and NF-200, without labeling glial markers GFAP and Olig2. Finally, these neuron-like cells show TTX-sensitive NA (+) currents and action potentials, which are not observed in MSC-siControl, which only present outward $\mathrm{K}^{+}$currents [100].

Barzilay et al. Used the delivery of lentiviral genes to exogenously administer the homeobox one beta LIM (LMX1b) transcription factor to bone marrow MSCs before differentiation with FGF-2 FGF-8, and SHH. Before induction, no change is observed in the expression levels of transcripts of typical midbrain dopaminergic genes such as MSX1, Sox2, Neurogenin 2, hASH1, En1, or Pitx3 in LMX1a transfected MSCs, similar to MSX transfected with a GFP control. However, after three weeks of induction, an impressive number of these factors are up-regulated in LMX1a MSCs compared to control MSCs. Furthermore, after differentiation, more than 90\% of LMX1a MSCs express Tuj1 compared to the baseline level of Tuj1 expression in undifferentiated MSCs. Some differentiated LMX1a MSCs stain positively for MAP2 and synapsin, and some express voltage-gated sodium channels typical of neurons. On the other hand, the positive regulation of the $\mathrm{TH}$ protein promoted by induction is significantly higher in 
LMX1a MSCs than control transfected MSCs after induction, which allows LMX1 MSCs to secrete three times more dopamine into the medium than induced control MSCs [101].

For their part, in 2013, Yan et al. Induced the ectopic expression of LMX1a and Neurturin in MSCs before their neural differentiation through exposure to $\beta$-Me, RA, bFGF, FGF-8, and SHH. After 21 days of induction, the transcriptional levels of TH, Msx-1, Nestin, MAP-2, $\operatorname{Lmx} 1 \beta$, Fox $\alpha 2$, Pitx3, DAT, $\beta$-tubulin III, Nurr1, and EN1 are significantly upregulated in transfected and induced MSCs, compared to control induced and transfected MSCs, and this was confirmed at the protein level by immunofluorescence analysis, where the results reveal staining for NSE, MAP-2, $\beta$-tubulin III, and TH in transfected MSCs as opposed to control MSCs [102].

In the same year, Wang et al. transfected murine bone marrow MSCs with a siRNA against Caveolin 1 before their neuronal differentiation with $\beta$-Me. Transfection alone did not generate significant morphological changes in MSCs. However, the levels of Notch-1, the intracellular domain of Notch (NICD), and Hes5 were markedly down-regulated in these cells after the transfection process. After treatment with $\beta$-Me, most cells present a typical neuronal appearance at six days of induction. Unlike other tests, in this study, the addition of $\beta$-Me generates an expression of Map2 at the mRNA level and protein and NSE. These effects on the morphology and the expression of neuronal proteins are increased in the transfected group. In addition, after a $6 \mathrm{~h}$ induction, the expression of caveolin-1 is positively regulated in both the transfected and control MSCs. At the same time, the levels of Notch-1, NICD, and Hes5 decreased significantly, particularly in the group of transfection with siRNA CAv1 [103].

Park and colleagues used a 2-step protocol to differentiate human MSCs into motor neurons. First, the ectopic expression of the Olig2 and/Hb9 genes was promoted in MSCs by delivery by viral vectors, to later treat these cells with $\beta$-Me, forskolin, RA, bFGF, and SHH for their differentiation. Treatment with these factors significantly increases NF-M mRNA levels in both transfected and non-transfected cells compared to untreated cells. However, the mRNA for Islet-1 and VAChT, markers of motor neurons, only increase when transfected cells are induced. After nine days of exposure to the induction medium, approximately $32 \%$ of the transfected cells adopt a neuron-like morphology, of which $18 \%$ maintain neuronal morphology even after two days of the removal of the induction medium. Electrophysiological assays demonstrate that the resting membrane potential of cells transfected and treated with induction medium is more negative than that of transfected non-induced MSCs. More than half of these cells exhibit evoked action potentials. Furthermore, these transfected and induced MSCs can form functional connections with muscle fibers in vitro, as a motor neuron would [104].

Differentiation of human MSCs was induced by gene transfection of NICD followed by culture in $\alpha$-MEM medium supplemented with forskolin, bFGF, and 
ciliary neurotrophic factor (CNTF). After transfection, MSCs show increased glutamate transporter GLAST and Nestin expression compared to untransfected MSCs. Five days after induction, the transfected and induced MSCs show neuron-like processes and express the neuronal markers MAP-2ab, NF-M, and $\beta$ tubulin III. Immunohistochemical assays show that more than $90 \%$ of the transfected MSCs stain positively for MAP-2ab, of which $89.4 \%$ also stain positively for NF-M and $\beta$-tubulin III after differentiation, while GFAP cells are not detected. Electrophysiological analysis shows that transfected and induced MSCs have a more negative resting membrane potential than control transfected MSCs. An increase in rectifying potassium current is seen in $58 \%$ of transfected and trophic factor-treated MSCs, but not fast voltage-gated sodium currents. Finally, the addition of GDNF to these cells increases the expression of Nurr-1, Lmx1b, En1, Ptx3 and increases the proportion of cells immunopositive for TH (41.0\%), compared to transfected and induced MSCs without GDNF (3.9\%), which allows them to synthesize and secrete dopamine to the culture medium in response to depolarizing stimuli [105].

In 2015, Liu et al. Transfected the human BDNF gene into guinea pig-derived MSCs and treated them with RA for neuronal differentiation. After culturing for $48 \mathrm{~h}$ with RA, the viability of transfected MSCs is greater than that of induced or non-induced non-transfected MSCs. Said cells transfected and exposed to RA have a morphology similar to a neuron, compared to untreated MSCs. Immunohistochemical and RT-PCR assays show that transfected MSCs express higher levels of nestin, BDNF, NSE, and GFAP, compared to non-transfected MSCs regardless of whether they were treated with RA or not. However, more cells positively co-stained for nestin, NSE and GFAP are detected in transfected MSCs subjected to differentiation than in non-induced ones [106] (Supplementary Table S6).

\section{Micro-RNA}

Jing et al. Transfected murine bone marrow MSCs with a viral vector containing the sequence of microRNA-9, and subsequently, the MSCs were induced into neurons by exposure to $\beta$-Me. In principle, the infected MSCs show a lower survival than the group transfected with empty vector, however after induction, the transfected MSCs show higher levels of MAP2 at both the RNA and protein levels, as well as a lower expression of Notch1, which induced cells without transfection [107].

For their part, Wu et al. Analyzed the action of mir-125-b in the neuronal transdifferentiation of murine bone marrow MSCs. They transfected them with a mimic miR-125b (Mimic), anti-miR-125b (group inhibitor), or without transfecting before its differentiation with $\beta$-Me. As expected, the relative folding of miR-125b increases significantly in the Mimic group but decreases considerably in the Inhibitor group. Neuronal differentiation, induction for six days, increases the levels of $\beta$-tubulin III, MAP-2, NF, NSE, GFAP, and Nestin at the messenger 
and protein level in the three experimental groups compared to the messenger and protein to the untreated group. However, the relative quantification of mRNA of these markers is significantly increased in the Mimic group compared to the untransfected $\beta$-Me group but significantly decreased in the inhibitor group. In addition, the induced MSCs of the mimic group acquire a morphology more similar to nerve cells for the untransfected cells. In contrast, in the inhibitor group, the morphological changes are not so noticeable and occur in only a few cells [108].

Duan et al. Infected MSCs with a lentivirus containing a miR-29a inhibitor before its induction with $\beta$-Me, DMSO, and BHA, finding that the drop in mir-29a promotes an increase in REST expression levels. There was a decrease in SNAP25, L1CAM, and the neuronal markers NES and Tau compared to the CMM induced without transfection. On the other hand, by treating these cells with a siRNA against REST, the expression of NSE and Tau is rescued, suggesting that miR-29a regulates neurogenic markers by targeting REST in induced MSCs [109].

On the other hand, Han et al. found that after exposing MSCs to these inducing factors, the expression of miRNA let-7f-5p is negatively regulated, while the expression of Par6 $\alpha$, a component of the Par3/Par6/aPKC complex, increases. Likewise, computerized analysis and luciferase assay show that Par6 $\alpha$ is a target gene for let-7f-5p. Using gain and loss of function approaches demonstrated that Par6 $\alpha$ and MAP2 expression are inversely correlated with the levels of let-7f-5p during differentiation. On the other hand, the silencing of Par6 $\alpha$ using siRNA attenuates the neuronal differentiation of MSCs by decreasing the levels of MAP-2, suggesting that inhibition of let-7f-5p facilitates MSC induction in neuron-like cells by targeting Par6 $\alpha$ directly [110].

Takeda \& Xu treated MSCs with exosomes derived from PC12 cells, a neuronal cell line, for one week to test their inducing power. Said exosomes were isolated from PC12 cells in different stages of differentiation with NGF, calling the exosome of undifferentiated PC12 cells "exosome D0", and the exosomes of PC12 cells treated with NGF for 3 and 9 days "D3" and "D9", respectively. On the other hand, as a control, MSCs were treated with exosomes derived from the B16-F10 melanoma cell line. After treatment with exosomes derived from the PC12 cell line, MSCs present neurite-like extensions, which are not observed in untreated MSCs or treated with B16-F10 exosomes. Likewise, the expression of MAP2 and NSE is positively regulated after treatment with exosomes D3 and D9.

Exosomes derived from the PC12 cell line were used to evaluate the possible differentiation mechanisms promoted by the miRNAs contained in the exosomes. There were 101 miRNAs in the exosome samples using microarrays, of which nine are positively regulated after treatment with NGF, compared to the exosomes of B16-F10 cells. In particular, the expression of miR-125b is 319 times higher in the D9 exosome compared to the B16-F10 exosome, which suggests 
that this miRNA, together with other components of the exosomes of neural cells, may play a role in the expression of neuronal markers in MSCs. In contrast, exosomes derived from B16-F10 cells and exosome D0 do not produce changes in the expression levels of these markers [111].

\section{Small Molecules}

In 2017 Alexanian et al. used their 2010 differentiation protocol together with the small molecules SB431542 and dorsomorphin (DM), two specific SMAD inhibitors that inhibit activin/nodal/TGF- $\beta$ signaling pathways bone morphogenic protein (BMP), respectively, to induce neuronal differentiation of human MSCs. After three weeks of induction, MSCs experience increases in various neuronal genes such as Sox2, Map2, $\beta$-tubulin III, NSE, Nurr-1, ChAT, TH, NF, VGLUT1, SYP, SYN-1, VGAT, GAD67, and PITX3, relative to untreated MSCs. Approximately $95 \%$ of the total cells subjected to differentiation present neuronal morphology, while the rest, although they present fibroblastic morphology, still express several neural markers. The cell count positive for specific neuronal markers shows that approximately $68.05 \%$ of the cells stain for TH, $89.12 \%$ for Nurr1, and $11.03 \%$ for ChAT. Synaptophysin immunostaining reveals synapse-like structures that form between differentiated cells [112].

Dual inhibition of small molecule-mediated activin/nodal/TGF- $\beta$ and BMP signaling pathways induces neurite outgrowth in MSCs after 14 days of exposure. It promotes increased expression of Pax6 transcription factors and Sox 1 and the expression of NF200, NES, and $\beta$-tubulin III. This process correlates with the activation of $\mathrm{p} 38$, Erk1/2, PI3K, and Akt signaling since enhanced phosphorylation of Erk, PI3K, and Akt is found in cells subjected to dual inhibition. Three years later, Madhu et al. used these two small molecules without adding any other factor as inducers in the neuronal differentiation of human MSCs derived from adipose tissue. The presence of NSE further confirmed the induction of a neuronal phenotype on day 14 in the cells treated with the inhibitors, where more than $85 \%$ of the MSCs treated with SB and DM stain positively for this neuronal marker [113].

J. Park et al. developed an optimal protocol for inducing adipose tissue-derived human MSCs in neuronal stem cell-like cells with more than $85 \%$ efficiency using small molecules. To do this, they treated bFGF pre-induced MSCs with three inhibitors of the BMP signaling pathway: SB431542, noggin, and LDN193289 for eight days. These cells were subsequently cultured for five days in a Neurobasal medium with the presence of ascorbic acid, B27, and N2, to finally replace the medium with a medium supplemented with EGF and bFGF for an additional seven days. The qRT-PCR analysis shows that the expression levels of the markers nestin, Sox1, Sox2, Pax6, Musashi1, vimentin, EMX1, Gli3, FoxG1, Tuj1, and Olig 2 are significantly increased in MSCs cultured in the presence of small molecules, compared to CMM without the addition of these. These cells grow as neurospheres in suspension culture. Flow cytometry analysis shows that the pro- 
portion of cells positive for NCAM, Nestin, and Ki67 is $85.4 \%, 92.9 \%$, and $76.8 \%$, respectively. Subsequently, these authors seeded the partially differentiated cells in a neuronal induction medium composed of Purmorphamin (SHH activator) and BDNF to support the maturation of these cells. After seven days of culture, the cells exhibit neuron-like structures characterized by distinctive bipolar or multipolar neurite outgrowth at the periphery of their cell bodies. The qRT-PCR analysis reveals that the cells show increases in the expression levels of TuJ1, MAP2, Dlx5, Lhx6, GAD67, and the sodium ion channel SCN5A, seven days after the addition of these factors. Quantitative analysis reveals that more than $75 \%$ of cells stain doubly positive for the immature neuronal markers $\mathrm{TuJ} 1$ and Pax6 and the mature neuronal markers MAP2 and NeuN.

In contrast, only $33 \%$ of cells express the astrocyte markers GFAP and S100 and $17 \%$ of oligodendrocytes OLIG2. Electrophysiological testing of these cells shows that neuron-like cells successfully elicit action potentials. Some cells show a depolarizing dip in membrane voltage produced to hyperpolarizing current injection. Furthermore, a spontaneous postsynaptic current is detected in the recorded cells, indicating that these cells are connected by synapses and form a neural network. Finally, it was shown that treating MSCs exposed to small molecules with dbAMPc and BDNF for 14 days promotes a significant increase in the expression levels of genes related to GABAergic neurons such as GABRA2, GABRA5, vGat, and GAD65, while immunostaining reveals that $67 \%$ of MAP2positive neuron-like cells also express GAD and 47\% doubly stain for MAP2 and GABA. The functional study of these cells shows that the cells exhibit electrophysiological characteristics of active GABAergic neurons, such as a fast $\mathrm{Na}(+)$ influx current during the depolarization of the membrane potential and an inhibitory postsynaptic current in the presence of NMDAR and AMPAR agonists [114].

In $2019 \mathrm{Hu}$ et al. Used the ROCK kinase inhibitor Fasudil to differentiate murine MSCs from bone marrow pretreated with bFGF. The small molecule induces morphological changes in the MSCs corresponding to neurons. The MSCs shrink from their fusiform shape to a round morphology with long and thin processes, forming networks and contacts with other cells. Compared to the control group, these neuron-like cells increase at the messenger and protein level of the neuronal markers NSE, nestin, and NF-M. Quantitative analysis shows that the positive mean rate of immunofluorescent staining is $69.35 \%$ for NF-M, $76.52 \%$ for NSE, and $78.95 \%$ for nestin. The differentiating effects of fasudil are partially inhibited with an inhibitor of the Wnt/ $\beta$-catenin pathway (XAV939), suggesting that the differentiation promoted by fasudil is probably due to the activation of this pathway [115].

\section{Retinoic Acid}

Sánchez-Ramos et al. carried out neuronal differentiation of human umbilical cord MSCs by exposing them to NGF and RA, a small molecule that functions as 
a ligand for the retinoic acid receptor. Treatment with this molecule promotes increased expression of the neural markers Musashi-1, $\beta$-tubulin III, Pleiotrophin, Nestin, Necdin, NeuN, and GFAP, which are expressed at relatively low levels of undifferentiated MSCs. Immunohistochemical analysis shows that $6.2 \%$ of the induced cells stain positively for Musashi-1, 18.7\% for $\beta$-tubulin III, and $66.2 \%$ for GFAP. Concomitant with the increased expression of these markers, there is a decrease in the expression of genes associated with the development of blood cell lines. DNA microarray analysis shows that MSCs grown in the presence of RA and NGF exhibit significant changes in the expression of 322 genes out of a total of 12,600 human genes represented on the DNA chip. And at least 20 can be bound to products found in developing neurons, glia, or neural cells [116].

Locatelli et al. induced the formation of spheres from murine bone marrow MSCs by their treatment with bFGF and EGF, similar to the neurospheres of the brain, of which $90 \%$ are positive for nestin. These spheres were then immunomagnetically selected to isolate Sca-1 and Thy-1 positive cells, subjected to differentiation with RA and SHH for 7 days. After induction, these cells present a polarized form (unipolar or bipolar) with long cytoplasmic processes. Approximately $40 \%$ show immunoreactivity for $\beta$-tubulin III and NF while expressing $\beta$-tubulin III, NSE, and mRNA at the level of the NF light chain [117].

In addition, murine bone marrow CMMs were treated in DMEM pre-induction medium supplemented with FBS, FGF2, B27, forskolin, and IBMX for $24 \mathrm{~h}$, to then induce their differentiation in DMEM medium supplemented with FGF2, insulin-transferrin-selenium supplements, B27, Forskolin, IBMX, and BDNF. Finally, cells were exposed to a combination of SHH and RA to improve neuronal differentiation. After treatment with $\mathrm{SHH}$ and RA, substantial increases in cells with neuronal morphology are observed. MSCs show a variety of neuronal antigens, including MAP2, TUJ1, Tau, NSE, NeuN, and NF, which increases the expression of the glutamate transporters VGLUT1 and VGLUT2, GluR3, and GluR4 receptors. It should be noted that the individual application of $\mathrm{SHH}$ or RA promotes little or no effect on the expression of these markers [118].

Cho et al. treated human bone marrow MSCs with a single dose of RA, generating MSCs with neuronal morphology by the seventh day of exposure. At this time point, the treated cells show a high positivity for MAP2 and a slight fluorescence for synaptophysin, which increases by day 12 of treatment. Additionally, this treatment generates that $80 \%$ of the cells are positively marked for neurofilament, MAP2, and nestin and that a large proportion of the cells subjected to differentiation generate action potentials [119].

Hermann et al. generated spheres derived from human MSCs from bone marrow donors young ( 18 - 35 years) and old ( $45-76$ years) by treatment with EGF and FGF-2, which differentiate in neurobasal medium supplemented with RA. This study revealed that after inducing differentiation in MSCs from old donors, more than $80 \%$ remain positive for fibronectin (FN), while no expres- 
sion of MAP2, GalC, or GFAP is observed. Furthermore, only 33\% of cells stain positively for $\beta$-tubulin III and $12 \%$ for nestin. In contrast, $42 \%$ of the treated cells derived from young donors are $\beta$-tubulin III positive, 6\% MAP2 positive, $13 \%$ GFAP positive, and 15\% GalC positive [120]. Likewise, these authors demonstrated that neurospheres treated with RA could undergo terminal neuronal differentiation by adding BDNF to the medium for 14 days. This modification causes a decrease in FN expression levels in the MSCs, NEUROD1, NGN2, and OTX1 while upregulating the expression of the early neuroectodermal gene MSI1. Furthermore, this protocol leads to a mature neuronal phenotype demonstrated by the expression of MAP2ab in about $6 \%$ of the cells and an increase in TUBB4/III, SNCA, and TH, as well as an increase in the expression of GFAP and MBP [121].

Gong et al. used RA as a pre-inductive agent for neuronal differentiation of murine bone marrow MSCs for $24 \mathrm{~h}$ before culturing them in a differentiation medium consisting of DMEM/F12 medium supplemented with DMSO, butylated hydroxyanisole, $\mathrm{KCl}$, valproic acid, forskolin, hydrocortisone, and insulin for $24 \mathrm{~h}$. After induction, MSCs transform into neural-like cells exhibiting distinct neuronal morphologies, including widely branched single, large, and multipolar, bipolar appearances. The neuronal differentiation efficiency of MSCs pretreated with RA is $83.17 \%$, significantly higher than that of MSCs without pretreatment (61.31\%). Likewise, pre-induced MSC-derived neural-type cells exhibit longer axonal length and more neurites. Together the mRNA and protein levels of the Nestin, NSE, MAP-2, Tau, and Tuj1 markers are higher in pre-induced cells. Electrophysiological analysis shows that RA-untreated MSC-derived neural-type cells hyperpolarize after neuronal induction compared to uninduced cells. However, a more significant effect is observed in cells treated with the small molecule. On the other hand, after stimulation with a high concentration of $\mathrm{K}^{+}$, there is a more significant increase in the intracellular calcium concentration in the induced cells than in the undifferentiated cells. At the same time, this effect is enhanced by pretreating the cells with RA [122].

Wang et al. showed that RA could induce efficient neural-type differentiation of bone marrow-derived murine MSCs. With the generation of neuron-like cells, increased expression of neuron-specific markers such as NSE, NF-H, $\beta$-tubulin, and MAP- 2 and the gradual decrease in the resting membrane potential of these cells after RA treatment. Furthermore, these authors found that myocardin-related transcription factor A (MRTF-A) is activated and translocated to the nucleus during RA-induced neural-type differentiation in MSCs. At the same time, the fall of MRTF-A significantly prevents the up-regulation of neuronal-specific gene expression in response to RA, partially suppressing the differentiation of these cells [123].

Gao et al. used RA to induce neuronal differentiation of MSCs derived from the yolk sac of a chicken embryo, observing that after the induction process, some of the cells show an elongated neuronal morphology with extended processes, as 
well as an increase in the expression of Nestin and Map-2, which are expressed at deficient levels in undifferentiated MSCs [124].

Recently Lu et al. induced the differentiation of human MSCs derived from the olfactory mucosa into photoreceptor cells by adding EGF, Taurine, and RA for ten days. Treatment with these factors leads to a substantial change in the cellular morphology of cells derived from the olfactory mucosa, where some cells show a spherical shape, an extended bulge, and the presence of primary and secondary branches. Immunofluorescence staining and western blot analysis indicate the presence of the rhodopsin protein, a positive marker for cells expressing induced photoreceptors [125] (Supplementary Table S7).

\section{Advantages and Disadvantages of Multiple Differentiation Protocols}

The choice of the optimal differentiation method must be made in a particular way considering several factors such as price and the intrinsic characteristics of the cells used to induce the differentiation process. The different methodologies reviewed show considerable variations in differentiation efficiency, maturation, neuronal marker expression, functionality, and cell survival. However, each procedure presents a series of favorable and unfavorable characteristics compared to each other. Table 1 summarizes the advantages and disadvantages of each differentiation method.

Table 1. Advantages and disadvantages of multiple differentiation protocols used to promote neural differentiation of MSCs.

\begin{tabular}{ll}
\hline Inductor & Advantages \\
\hline Chemical & $\begin{array}{l}\text { 1. Induced cells rapidly change to neuronal morphology } \\
\text { compounds }\end{array}$ \\
& $\begin{array}{l}\text { (in minutes or hours). } \\
\text { The inductors used are usually available in most } \\
\text { laboratories. }\end{array}$
\end{tabular}

\section{Disadvantages}

1. Most protocols require a pre-induction step and an induction step.

2. Expression of a few neuronal markers. Some are expressed at baseline in undifferentiated MSCs.

3. The morphological changes observed may be produced by toxicity or cell stress rather than a differentiation process.

4. Most studies that use chemical substances as inducers show the efficiency for morphological changes but not for immunostaining for neuronal markers.

Growth 1. They produce an efficient differentiation factors

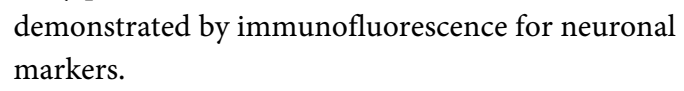
demonstrated by immunofluorescence for neuronal markers.

2. Induction with these factors is very similar to that carried out endogenously.

3. Some protocols generate mature neurons with phenotypic and electrophysiological properties characteristic of neurons.
1. Its acquisition is more expensive compared to the other methods.

2. Cocktails of various growth factors are often required for effective induction.

3. Long exposure times are needed to observe the first morphological changes. 
Continued

Coculture

Gene transfection

1. The tests make it possible to find determining genes for the neuronal differentiation of MSCs.

2. Most assays generate neurons with electrophysiological and phenotypic characteristics of mature neurons.

3. The neurons generated can release neurotransmitters
1. It cannot rule out the possibility of cellular fusion between MSC and mature neurons.

2. In addition to co-cultivation, the protocols require exposure to chemicals or growth factors.

3. The factors that promote differentiation are not fully identified. to the environment, demonstrating their functionality.

4. Isolating neuronal cells is often complex and requires trained personnel to perform it.

1. The transfection process is complex and often expensive.

2. Differentiation also depends on the characteristics of the cells to be differentiated from the percentage of transfection efficiency.

3. Some cells isolated from individuals with pathologies are difficult to transfect, making their application challenging to study diseases.

4. It takes exposure to other inducers.

Small molecules
1. Facilitate accurate, fast, and efficient differentiation of 1 . Specific cocktails may be required to generate the MSCs. desired effect.

2. The effects on differentiation are specific by activating 2 . They have been used in recent years, but they are or inhibiting critical molecules in the differentiation less known than the other differentiation protocols.

3. The effects are dose-dependent, reversible, and highly reproducible.

4. Ease of handling and storage.

5. They are less expensive than growth factors.

\section{Conclusion}

The ability of MSCs to differentiate into neural lineages makes them a promising and a potential tool to generate new advances in the field of cell therapy and regenerative medicine. This review summarized and compared multiple effective methods to induce this differentiation. However, differentiation can vary depending on the site of collection, the methodology used, the physiological state, and the individual's age from which they were isolated. There is a need for current research and procedures that could provide new insights for a better understanding that could help develop and design new therapies for treating neurological and neurodegenerative diseases.

\section{Conflicts of Interest}

The authors declare no conflicts of interest regarding the publication of this paper.

\section{References}

[1] Ahuja, C.S., Mothe, A., Khazaei, M., Badhiwala, J.H., Gilbert, E.A., Kooy, D., et al. 
(2020) The Leading Edge: Emerging Neuroprotective and Neuroregenerative Cell-Based Therapies for Spinal Cord Injury. Stem Cells Translational Medicine, 9, 1509-1530. https://onlinelibrary.wiley.com/doi/abs/10.1002/sctm.19-0135 https://doi.org/10.1002/sctm.19-0135

[2] Socarrás-Ferrer, L.B., del Valle-Pérez, L.L.O., et al. (2013) Células madre mesenquimales: Aspectos relevantes y aplicación clínica en la medicina regenerativa. Revista Cubana de Hematología, Inmunología y Hemoterapia, 29, 16-23. http://scielo.sld.cu/scielo.php?script=sci arttext\&pid=S0864-02892013000100003

[3] Dominici, M., Le Blanc, K., Mueller, I., Slaper-Cortenbach, I., Marini, F.C., Krause, D.S., et al. (2006) Minimal Criteria for Defining Multipotent Mesenchymal Stromal Cells. The International Society for Cellular Therapy Position Statement. Cytotherapy, 8, 315-317. https://doi.org/10.1080/14653240600855905

[4] Lukomska, B., Stanaszek, L., Zuba-Surma, E., Legosz, P., Sarzynska, S. and Drela, K. (2019) Challenges and Controversies in Human Mesenchymal Stem Cell Therapy. Stem Cells International, 2019, Article ID: 9628536. https://doi.org/10.1155/2019/9628536

[5] Lee, K.-D., Kuo, T.K.C., Whang-Peng, J, Chung, Y.F., Lin, C.T., Chou, S.H., et al. (2004) In Vitro Hepatic Differentiation of Human Mesenchymal Stem Cells. Hepatology, 40, 1275-1284. https://pubmed.ncbi.nlm.nih.gov/15562440/ https://doi.org/10.1002/hep.20469

[6] Chen, L.B., Jiang, X.B. and Yang, L. (2004) Differentiation of Rat Marrow Mesenchymal Stem Cells into Pancreatic Islet Beta-Cells. World Journal of Gastroenterology, 10, 3016-3020. https://doi.org/10.3748/wjg.v10.i20.3016

[7] Shi, Y., Hu, Y., Lv, C. and Tu, G. (2016) Effects of Reactive Oxygen Species on Differentiation of Bone Marrow Mesenchymal Stem Cells. Annals of Transplantation, 21, 695-700. https://doi.org/10.12659/AOT.900463

[8] Ayala-Grosso, C., Pieruzzini, R., Vargas-Saturno, L. and Cardier, J.E. (2020) Human Olfactory Mesenchymal Stromal Cells Co-Expressing Horizontal Basal and Ensheathing Cell Proteins in Culture. Biomedica, 40, 72-88. https://doi.org/10.7705/biomedica.4762

[9] Ying, C., Hu, W., Cheng, B., Zheng, X. and Li, S. (2012) Neural Differentiation of Rat Adipose-Derived Stem Cells in Vitro. Cellular and Molecular Neurobiology, 32, 1255-1263. https://link.springer.com/article/10.1007/s10571-012-9850-2 https://doi.org/10.1007/s10571-012-9850-2

[10] Pittenger, M.F. (1999) Multilineage Potential of Adult Human Mesenchymal Stem Cells. Science, 284, 143-147.

https://www.sciencemag.org/lookup/doi/10.1126/science.284.5411.143 https://doi.org/10.1126/science.284.5411.143

[11] Jackson, W.M., Nesti, L.J. and Tuan, R.S. (2010) Potential Therapeutic Applications of Muscle-Derived Mesenchymal Stem and Progenitor Cells. Expert Opinion on Biological Therapy, 10, 505-517. https://doi.org/10.1517/14712591003610606

[12] Chen, P.M., Yen, M.L., Liu, K.J., Sytwu, H.K. and Yen, B.L. (2011) Immunomodulatory Properties of Human Adult and Fetal Multipotent Mesenchymal Stem Cells. Journal of Biomedical Science, 18, Article No. 49.

http://www.jbiomedsci.com/content/18/1/49 https://doi.org/10.1186/1423-0127-18-49

[13] Bas, E., Van De Water, T.R., Lumbreras, V., Rajguru, S., Goss, G., Hare, J.M., et al. (2014) Adult Human Nasal Mesenchymal-Like Stem Cells Restore Cochlear Spiral Ganglion Neurons after Experimental Lesion. Stem Cells and Development, 23, $502-$ 
514. https://doi.org/10.1089/scd.2013.0274

[14] Delorme, B., Nivet, E., Gaillard, J., Häupl, T., Ringe, J., Devèze, A., et al. (2010) The Human Nose Harbors a Niche of Olfactory Ectomesenchymal Stem Cells Displaying Neurogenic and Osteogenic Properties. Stem Cells and Development, 19, 853-866. https://doi.org/10.1089/scd.2009.0267

[15] Kern, S., Eichler, H., Stoeve, J., Klüter, H. and Bieback, K. (2006) Comparative Analysis of Mesenchymal Stem Cells from Bone Marrow, Umbilical Cord Blood, or Adipose Tissue. Stem Cells, 24, 1294-1301.

https://stemcellsjournals.onlinelibrary.wiley.com/doi/full/10.1634/stemcells.2005-0342 https://doi.org/10.1634/stemcells.2005-0342

[16] Tremain, N., Korkko, J., Ibberson, D., Kopen, G.C., DiGirolamo, C. and Phinney, D.G. (2001) MicroSAGE Analysis of 2,353 Expressed Genes in a Single Cell-Derived Colony of Undifferentiated Human Mesenchymal Stem Cells Reveals mRNAs of Multiple Cell Lineages. Stem Cells, 19, 408-418.

https://pubmed.ncbi.nlm.nih.gov/11553849/

https://doi.org/10.1634/stemcells.19-5-408

[17] Weiss, M.L., Medicetty, S., Bledsoe, A.R., Rachakatla, R.S., Choi, M., Merchav, S., et al. (2006) Human Umbilical Cord Matrix Stem Cells: Preliminary Characterization and Effect of Transplantation in a Rodent Model of Parkinson's Disease. Stem Cells, 24, 781-792. https://doi.org/10.1634/stemcells.2005-0330

[18] Zhong, C., Qin, Z., Zhong, C.J., Wang, Y. and Shen, X.Y. (2003) Neuroprotective Effects of Bone Marrow Stromal Cells on Rat Organotypic Hippocampal Slice Culture Model of Cerebral Ischemia. Neuroscience Letters, 342, 93-96. https://doi.org/10.1016/S0304-3940(03)00255-6

[19] Chen, X., Katakowski, M., Li, Y., Lu, D., Wang, L., Zhang, L., et al. (2002) Human Bone Marrow Stromal Cell Cultures Conditioned by Traumatic Brain Tissue Extracts: Growth Factor Production. Journal of Neuroscience Research, 69, 687-691. http://doi.wiley.com/10.1002/jnr.10334 https://doi.org/10.1002/jnr.10334

[20] Himes, B.T., Neuhuber, B., Coleman, C., Kushner, R., Swanger, S.A., Kopen, G.C., et al. (2006) Recovery of Function Following Grafting of Human Bone MarrowDerived Stromal Cells into the Injured Spinal Cord. Neurorehabilitation and Neural Repair, 20, 278-296. http://journals.sagepub.com/doi/10.1177/1545968306286976 https://doi.org/10.1177/1545968306286976

[21] Xun, C., Ge, L., Tang, F., Wang, L., Zhuo, Y., Long, L., et al. (2020) Insight into the Proteomic Profiling of Exosomes Secreted by Human OM-MSCs Reveals a New Potential Therapy. Biomedicine \& Pharmacotherapy, 131, Article ID: 110584. https://doi.org/10.1016/j.biopha.2020.110584

[22] Xin, H., Li, Y., Liu, Z., Wang, X., Shang, X., Cui, Y., et al. (2013) MiR-133b Promotes Neural Plasticity and Functional Recovery after Treatment of Stroke with Multipotent Mesenchymal Stromal Cells in Rats via Transfer of Exosome-Enriched Extracellular Particles. Stem Cells, 31, 2737-2746.

https://pubmed.ncbi.nlm.nih.gov/23630198/ https://doi.org/10.1002/stem.1409

[23] Jin, M., Chen, Y., Zhou, Y., Mei, Y., Liu, W., Pan, C., et al. (2016) Transplantation of Bone Marrow-Derived Mesenchymal Stem Cells Expressing Elastin Alleviates Pelvic Floor Dysfunction. Stem Cell Research \& Therapy, 7, Article No. 51. http://stemcellres.biomedcentral.com/articles/10.1186/s13287-016-0308-1 https://doi.org/10.1186/s13287-016-0308-1

[24] Klein, A., Barsky, L.W., Wu, G., Zhu, H., Mitsuhashi, N., Weinberg, K., et al. (2009) 
The Role of the Hyaluronan Receptor CD44 in Mesenchymal Stem Cell Migration in the Extracellular Matrix. https://pubmed.ncbi.nlm.nih.gov/16306150/

[25] Patel, D.M., Shah, J. and Srivastava, A.S. (2013) Therapeutic Potential of Mesenchymal Stem Cells in Regenerative Medicine. Stem Cells International, 2013, Article ID: 496218. https://doi.org/10.1155/2013/496218

[26] Kopen, G.C., Prockop, D.J. and Phinney, D.G. (1999) Marrow Stromal Cells Migrate throughout Forebrain and Cerebellum, and They Differentiate into Astrocytes after Injection into Neonatal Mouse Brains. Proceedings of the National Academy of Sciences of the United States of America, 96, 10711-10716. https://doi.org/10.1073/pnas.96.19.10711

[27] Azizi, S.A., Stokes, D., Augelli, B.J., DiGirolamo, C. and Prockop, D.J. (1998) Engraftment and Migration of Human Bone Marrow Stromal Cells Implanted in the Brains of Albino Rats-Similarities to Astrocyte Grafts. Proceedings of the National Academy of Sciences of the United States of America, 95, 3908-3913. https://doi.org/10.1073/pnas.95.7.3908

[28] Eglitis, M.A., Dawson, D., Park, K.W. and Mouradian, M.M. (1999) Targeting of Marrow-Derived Astrocytes to the Ischemic Brain. Neuroreport, 10, 1289-1292. https://doi.org/10.1097/00001756-199904260-00025

[29] Jendelová, P., Herynek, V., Urdzíková, L., Glogarová, K., Kroupová, J., Andersson, B., et al. (2004) Magnetic Resonance Tracking of Transplanted Bone Marrow and Embryonic Stem Cells Labeled by Iron Oxide Nanoparticles in Rat Brain and Spinal Cord. Journal of Neuroscience Research, 76, 232-243.

http://doi.wiley.com/10.1002/jnr.20041 https://doi.org/10.1002/jnr.20041

[30] Nivet, E., Vignes, M., Girard, S.D., Pierrisnard, C., Baril, N., Devèze, A., et al. (2011) Engraftment of Human Nasal Olfactory Stem Cells Restores Neuroplasticity in Mice with Hippocampal Lesions. Journal of Clinical Investigation, 121, 2808-2820. https://doi.org/10.1172/JCI44489

[31] Wang, L., Li, Y., Chen, J., Gautam, S.C., Zhang, Z., Lu, M., et al. (2002) Ischemic Cerebral Tissue and MCP-1 Enhance Rat Bone Marrow Stromal Cell Migration in Interface Culture. Experimental Hematology, 30, 831-836. https://doi.org/10.1016/S0301-472X(02)00829-9

[32] Girard, S.D., Virard, I., Lacassagne, E., Paumier, J.M., Lahlou, H., Jabes, F., et al. (2017) From Blood to Lesioned Brain: An in Vitro Study on Migration Mechanisms of Human Nasal Olfactory Stem Cells. Stem Cells International, 2017, Article ID: 1478606.https://doi.org/10.1155/2017/1478606

[33] Ould-Yahoui, A., Sbai, O., Baranger, K., Bernard, A., Gueye, Y., Charrat, E., et al. (2013) Role of Matrix Metalloproteinases in Migration and Neurotrophic Properties of Nasal Olfactory Stem and Ensheathing Cells. Cell Transplantation, 22, 993-1010. https://pubmed.ncbi.nlm.nih.gov/23043957/ https://doi.org/10.3727/096368912X657468

[34] Aggarwal, S. and Pittenger, M.F. (2005) Human Mesenchymal Stem Cells Modulate Allogeneic Immune Cell Responses. Blood, 105, 1815-1822. http://ashpublications.org/blood/article-pdf/105/4/1815/1707068/zh800405001815.pdf https://doi.org/10.1182/blood-2004-04-1559

[35] Ramesh, R., Jeyaraman, M., Chaudhari, K., Dhamsania, H. and G. S., P. (2018) Mesenchymal Stem Cells-A Boon to Orthopedics. Open Journal of Regenerative Medicine, 7, 19-27. http://www.scirp.org/journal/PaperInformation.aspx?PaperID=88454 https://doi.org/10.4236/ojrm.2018.72002 
[36] Enomoto, M. (2015) The Future of Bone Marrow Stromal Cell Transplantation for the Treatment of Spinal Cord Injury. Neural Regeneration Research, 10, 383-384. https://www.ncbi.nlm.nih.gov/pmc/articles/PMC4396098/ https://doi.org/10.4103/1673-5374.153684

[37] Haack-Sorensen, M., Bindslev, L., Mortensen, S., Friis, T. and Kastrup, J. (2007) The Influence of Freezing and Storage on the Characteristics and Functions of Human Mesenchymal Stromal Cells Isolated for Clinical Use. Cytotherapy, 9, 328-337. https://doi.org/10.1080/14653240701322235

[38] Mueller, S.M. and Glowacki, J. (2001) Age-Related Decline in the Osteogenic Potential of Human Bone Marrow Cells Cultured in Three-Dimensional Collagen Sponges. Journal of Cellular Biochemistry, 82, 583-590. https://onlinelibrary.wiley.com/doi/full/10.1002/jcb.1174 https://doi.org/10.1002/jcb.1174

[39] Oñate, B., Vilahur, G., Ferrer-Lorente, R., Ybarra, J., Díez-Caballero, A., Ballesta-López, C., et al. (2012) The Subcutaneous Adipose Tissue Reservoir of Functionally Active Stem Cells Is Reduced in Obese Patients. The FASEB Journal, 26, 4327-4336.

http://www.fasebj.org https://doi.org/10.1096/fj.12-207217

[40] Li, Y., Chopp, M., Chen, J., Wang, L., Gautam, S.C., Xu, Y.X., et al. (2000) Intrastriatal Transplantation of Bone Marrow Nonhematopoietic Cells Improves Functional Recovery after Stroke in Adult Mice. Journal of Cerebral Blood Flow \& Metabolism, 20, 1311-1319.

http://journals.sagepub.com/doi/10.1097/00004647-200009000-00006 https://doi.org/10.1097/00004647-200009000-00006

[41] Zhao, L.R., Duan, W.M., Reyes, M., Keene, C.D., Verfaillie, C.M. and Low, W.C. (2002) Human Bone Marrow Stem Cells Exhibit Neural Phenotypes and Ameliorate Neurological Deficits after Grafting into the Ischemic Brain of Rats. Experimental Neurology, 174, 11-20. https://doi.org/10.1006/exnr.2001.7853

[42] Li, Y., Chen, J., Zhang, C.L., Wang, L., Lu, D., Katakowski, M., et al. (2005) Gliosis and Brain Remodeling after Treatment of Stroke in Rats with Marrow Stromal Cells. Glia, 49, 407-417. http://doi.wiley.com/10.1002/glia.20126 https://doi.org/10.1002/glia.20126

[43] Chen, J., Li, Y., Katakowski, M., Chen, X., Wang, L., Lu, D., et al. (2003) Intravenous Bone Marrow Stromal Cell Therapy Reduces Apoptosis and Promotes Endogenous Cell Proliferation after Stroke in Female Rat. Journal of Neuroscience Research, 73, 778-786. http://doi.wiley.com/10.1002/jnr.10691 https://doi.org/10.1002/jnr.10691

[44] Sasaki, M., Honmou, O., Akiyama, Y., Uede, T., Hashi, K. and Kocsis, J.D. (2001) Transplantation of an Acutely Isolated Bone Marrow Fraction Repairs Demyelinated Adult Rat Spinal Cord Axons. Glia, 35, 26-34.

https://doi.org/10.1002/glia.1067

[45] Akiyama, Y., Radtke, C. and Kocsis, J.D. (2002) Remyelination of the Rat Spinal Cord by Transplantation of Identified Bone Marrow Stromal Cells. Journal of Neuroscience, 22, 6623-6630. https://doi.org/10.1523/JNEUROSCI.22-15-06623.2002

[46] Akiyama, Y., Radtke, C., Honmou, O. and Kocsis, J.D. (2002) Remyelination of the Spinal Cord Following Intravenous Delivery of Bone Marrow Cells. Glia, 39, 229-236. https://doi.org/10.1002/glia.10102

[47] Chopp, M., Zhang, X.H., Li, Y., Wang, L., Chen, J., Lu, D., et al. (2000) Spinal Cord Injury in Rat. Neuroreport, 11, 3001-3005.

http://journals.lww.com/00001756-200009110-00035 
https://doi.org/10.1097/00001756-200009110-00035

[48] Hofstetter, C.P., Schwarz, E.J., Hess, D., Widenfalk, J., El Manira, A., Prockop, D.J., et al. (2002) Marrow Stromal Cells form Guiding Strands in the Injured Spinal Cord and Promote Recovery. Proceedings of the National Academy of Sciences of the United States of America, 99, 2199-2204. https://doi.org/10.1073/pnas.042678299

[49] Čížková, D., Rosocha, J., Vanický, I., Jergová, S. and Čížek, M. (2006) Transplants of Human Mesenchymal Stem Cells Improve Functional Recovery after Spinal Cord Injury in the Rat. Cellular and Molecular Neurobiology, 26, 1165-1178.

http://link.springer.com/10.1007/s10571-006-9093-1

https://doi.org/10.1007/s10571-006-9093-1

[50] Zurita, M. and Vaquero, J. (2004) Functional Recovery in Chronic Paraplegia after Bone Marrow Stromal Cells Transplantation. Neuroreport, 15, 1105-1108.

http://journals.lww.com/00001756-200405190-00004 https://doi.org/10.1097/00001756-200405190-00004

[51] Li, Y., Chen, J., Wang, L., Zhang, L., et al. (2001) Intracerebral Transplantation of Bone Marrow Stromal Cells in a 1-Methyl-4-phenyl-1,2,3,6-tetrahydropyridine Mouse Model of Parkinson's Disease. Neuroscience Letters, 316, 67-70.

https://pubmed.ncbi.nlm.nih.gov/11742717/

https://doi.org/10.1016/S0304-3940(01)02384-9

[52] Dezawa, M., Takahashi, I., Esaki, M., Takano, M. and Sawada, H. (2001) Sciatic Nerve Regeneration in Rats Induced by Transplantation of in Vitro Differentiated Bone-Marrow Stromal Cells. European Journal of Neuroscience, 14, 1771-1776. https://onlinelibrary.wiley.com/doi/full/10.1046/j.0953-816x.2001.01814.x https://doi.org/10.1046/j.0953-816x.2001.01814.x

[53] Pedram, M.S., Dehghan, M.M., Soleimani, M., Sharifi, D., Marjanmehr, S.H. and Nasiri, Z. (2010) Transplantation of a Combination of Autologous Neural Differentiated and Undifferentiated Mesenchymal Stem Cells into Injured Spinal Cord of Rats. Spinal Cord, 48, 457-463. https://www.nature.com/sc https://doi.org/10.1038/sc.2009.153

[54] Black, I.B. and Woodbury, D. (2001) Adult rat and Human Bone Marrow Stromal Stem Cells Differentiate into Neurons. Blood Cells, Molecules and Diseases, 27, 632-636. https://pubmed.ncbi.nlm.nih.gov/11482877/ https://doi.org/10.1006/bcmd.2001.0423

[55] Zuk, P.A., Zhu, M., Ashjian, P., De Ugarte, D.A., Huang, J.I., Mizuno, H., et al. (2002) Human Adipose Tissue Is a Source of Multipotent Stem Cells. Molecular Biology of the Cell, 13, 4279-4295. https://doi.org/10.1091/mbc.e02-02-0105

[56] Hung, S., Cheng, H., Pan, C., Tsai, M.J., Kao, L. and Ma, H. (2002) In Vitro Differentiation of Size-Sieved Stem Cells into Electrically Active Neural Cells. Stem Cells, 20, 522-529. https://pubmed.ncbi.nlm.nih.gov/12456960/ https://doi.org/10.1634/stemcells.20-6-522

[57] Khanabdali, R., Saadat, A., Fazilah, M., Bazli, K.F.K., Qazi, R., Khalid, R., et al. (2016) Promoting Effect of Small Molecules in Cardiomyogenic and Neurogenic Differentiation of Rat Bone Marrow-Derived Mesenchymal Stem Cells. Drug Design, Development and Therapy, 10, 81-91. https://doi.org/10.2147/DDDT.S89658

[58] Hou, L., Cao, H., Wang, D., Wei, G., Bai, C., Zhang, Y., et al. (2003) Induction of Umbilical Cord Blood Mesenchymal Stem Cells into Neuron-Like Cells in Vitro. International Journal of Hematology, 78, 256-261. https://doi.org/10.1007/BF02983804

[59] Vaquero, J., Horcajo, C.B., Otero, L., Aguayo, C., de Oya Otero, S. and Zurita, M. 
(2008) Diferenciación neural de células del estroma de médula ósea humana en presencia de líquido cefalorraquídeo. Trauma, 19, 212-217. https://dialnet.unirioja.es/servlet/articulo? codigo $=3434255$

[60] Nan, C., Guo, L., Zhao, Z., Ma, S., Liu, J., Yan, D., et al. (2016) Tetramethylpyrazine Induces Differentiation of Human Umbilical Cord-Derived Mesenchymal Stem Cells into Neuron-Like Cells in Vitro. International Journal of Oncology, 48, 22872294. https://doi.org/10.3892/ijo.2016.3449

[61] Deng, W., Prockop, D.J., Obrocka, M. and Fischer, I. (2001) In Vitro Differentiation of Human Marrow Stromal Cells into Early Progenitors of Neural Cells by Conditions That Increase Intracellular Cyclic AMP. Biochemical and Biophysical Research Communications, 282, 148-152. https://pubmed.ncbi.nlm.nih.gov/11263984/ https://doi.org/10.1006/bbrc.2001.4570

[62] Ashjian, P.H., Elbarbary, A.S., Edmonds, B., DeUgarte, D., Zhu, M., Zuk, P.A., et al. (2003) In Vitro Differentiation of Human Processed Lipoaspirate Cells into Early Neural Progenitors. Plastic and Reconstructive Surgery, 111, 1922-1931.

http://journals.lww.com/00006534-200305000-00018 https://doi.org/10.1097/01.PRS.0000055043.62589.05

[63] Long, X., Olszewski, M., Huang, W. and Kletzel, M. (2005) Neural Cell Differentiation in Vitro from Adult Human Bone Marrow Mesenchymal Stem Cells. Stem Cells and Development, 14, 65-69. https://doi.org/10.1089/scd.2005.14.65

[64] Tio, M., Tan, K.H., Lee, W., Wang, T.T. and Udolph, G. (2010) Roles of db-cAMP, IBMX and RA in Aspects of Neural Differentiation of Cord Blood Derived Mesenchymal-Like Stem Cells. PLoS ONE, 5, e9398. https://doi.org/10.1371/journal.pone.0009398

[65] Benítez-King, G., Riquelme, A., Ortíz-López, L., Berlanga, C., Rodríguez-Verdugo, M.S., Romo, F., et al. (2011) A Non-Invasive Method to Isolate the Neuronal Linage from the Nasal Epithelium from Schizophrenic and Bipolar Diseases. Journal of Neuroscience Methods, 201, 35-45. https://doi.org/10.1016/j.jneumeth.2011.07.009

[66] Shahbazi, A., Safa, M., Alikarami, F., Kargozar, S., Asadi, M.H., Joghataei, M.T., et al. (2016) Rapid Induction of Neural Differentiation in Human Umbilical Cord Matrix Mesenchymal Stem Cells by cAMP-Elevating Agents. International Journal of Molecular and Cellular Medicine, 5, 167-177.

https://www.ncbi.nlm.nih.gov/pmc/articles/PMC5125369/

[67] Alexania, A.R. (2007) Epigenetic Modifiers Promote Efficient Generation of Neural-Like Cells from Bone Marrow-Derived Mesenchymal Cells Grown in Neural Environment. Journal of Cellular Biochemistry, 100, 362-371.

http://doi.wiley.com/10.1002/jcb.21029

https://doi.org/10.1002/jcb.21029

[68] Alexanian, A.R. (2010) An Efficient Method for Generation of Neural-Like Cells from Adult Human Bone Marrow-Derived Mesenchymal Stem Cells. Regenerative Medicine, 5, 891-900. https://doi.org/10.2217/rme.10.67

[69] Zhang, Z and Alexanian, A.R. (2012) Dopaminergic-Like Cells from Epigenetically Reprogrammed Mesenchymal Stem Cells. Journal of Cellular and Molecular Medicine, 16, 2708-2714. https://doi.org/10.1111/j.1582-4934.2012.01591.x

[70] Zheng, Y., Huang, C., Liu, F., Lin, H., Yang, X and Zhang, Z. (2017) Comparison of the Neuronal Differentiation Abilities of Bone Marrow-Derived and Adipose Tissue-Derived Mesenchymal Stem Cells. Molecular Medicine Reports, 16, 3877-3886. https://doi.org/10.3892/mmr.2017.7069

[71] Fila-Danilow, A., Borkowska, P., Paul-Samojedny, M., Kowalczyk, M and Kowalski, 
J. (2017) The Influence of TSA and VPA on the in Vitro Differentiation of Bone Marrow Mesenchymal Stem Cells into Neuronal Lineage Cells: Gene Expression Studies. Advances in Hygiene and Experimental Medicine, 71, 236-242.

https://pubmed.ncbi.nlm.nih.gov/28397704/

https://doi.org/10.5604/01.3001.0010.3809

[72] Goodwin, H.S., Bicknese, A.R., Chien, S.N., Bogucki, B.D., Oliver, D.A., Quinn, C.O., et al. (2001) Multilineage Differentiation Activity by Cells Isolated from Umbilical Cord Blood: Expression of Bone, Fat, and Neural Markers. Biology of Blood and Marrow Transplantation, 7, 581-588.

https://pubmed.ncbi.nlm.nih.gov/11760145/

https://doi.org/10.1053/bbmt.2001.v7.pm11760145

[73] Peng, J., Wang, Y., Zhang, L., Zhao, B., Zhao, Z., Chen, J.F., et al. (2011) Human Umbilical Cord Wharton's Jelly-Derived Mesenchymal Stem Cells Differentiate into a Schwann-Cell Phenotype and Promote Neurite Outgrowth in Vitro. Brain Research Bulletin, 84, 235-243. https://doi.org/10.1016/j.brainresbull.2010.12.013

[74] Jiang, Y., Jahagirdar, B.N., Reinhardt, R.L., Schwartz, R.E., Keene, C.D., Ortiz-Gonzalez, X.R., et al. (2002) Pluripotency of Mesenchymal Stem Cells Derived from Adult Marrow. Nature, 418, 41-49. https://doi.org/10.1038/nature00870

[75] Jin, K., Mao, X.O., Batteur, S., Sun, Y and Greenberg, D.A. (2003) Induction of Neuronal Markers in Bone Marrow Cells: Differential Effects of Growth Factors and Patterns of Intracellular Expression. Experimental Neurology, 184, 78-89. https://doi.org/10.1016/S0014-4886(03)00133-X

[76] Tropel, P., Platet, N., Platel, J.-C., Noël, D., Albrieux, M., Benabid, A.-L., et al. (2006) Functional Neuronal Differentiation of Bone Marrow-Derived Mesenchymal Stem Cells. Stem Cells, 24, 2868-2876. https://pubmed.ncbi.nlm.nih.gov/16902198/ https://doi.org/10.1634/stemcells.2005-0636

[77] Trzaska, K.A., Kuzhikandathil, E.V and Rameshwar, P. (2007) Specification of a Dopaminergic Phenotype from Adult Human Mesenchymal Stem Cells. Stem Cells, 25, 2797-2808.

https://stemcellsjournals.onlinelibrary.wiley.com/doi/full/10.1634/stemcells.2007-0212 https://doi.org/10.1634/stemcells.2007-0212

[78] Datta, I., Mishra, S., Mohanty, L., Pulikkot, S and Joshi, P.G. (2011) Neuronal Plasticity of Human Wharton'S Jelly Mesenchymal Stromal Cells to the Dopaminergic Cell Type Compared with Human Bone Marrow Mesenchymal Stromal Cells. Cytotherapy, 13, 918-932. https://doi.org/10.3109/14653249.2011.579957

[79] Chun, S.Y., Soker, S., Jang, Y.J., Kwon, T.G and Yoo, E.S. (2016) Differentiation of Human Dental Pulp Stem Cells into Dopaminergic Neuron-Like Cells in Vitro. Journal of Korean Medical Science, 31, 171-177. https://doi.org/10.3346/jkms.2016.31.2.171

[80] Wang, J., Wang, X., Sun, Z., Wang, X., Yang, H., Shi, S., et al. (2010) Stem Cells from Human-Exfoliated Deciduous Teeth Can Differentiate into Dopaminergic Neuron-Like Cells. Stem Cells and Development, 19, 1375-1383.

https://doi.org/10.1089/scd.2009.0258

[81] Wang, N., Sun, C., Huo, S., Zhang, Y., Zhao, J., Zhang, S., et al. (2008) Cooperation of Phosphatidylcholine-Specific Phospholipase C and Basic Fibroblast Growth Factor in the Neural Differentiation of Mesenchymal Stem Cells in Vitro. International Journal of Biochemistry and Cell Biology, 40, 294-306. https://doi.org/10.1016/j.biocel.2007.08.003

[82] Marei, H.E.S., El-Gamal, A., Althani, A., Afifi, N., Abd-Elmaksoud, A., Farag, A., et 
al. (2018) Cholinergic and Dopaminergic Neuronal Differentiation of Human Adipose Tissue Derived Mesenchymal Stem Cells. Journal of Cellular Physiology, 233, 936-945. http://doi.wiley.com/10.1002/jcp.25937

https://doi.org/10.1002/jcp.25937

[83] Mareschi, K., Rustichelli, D., Comunanza, V., De Fazio, R., Cravero, C., Morterra, G., et al. (2009) Multipotent Mesenchymal Stem Cells from Amniotic Fluid Originate Neural Precursors with Functional Voltage-Gated Sodium Channels. Cytotherapy, 11, 534-547. https://pubmed.ncbi.nlm.nih.gov/19548144/ https://doi.org/10.1080/14653240902974024

[84] Jang, S., Cho, H.H., Cho, Y.B., Park, J.S and Jeong, H.S. (2010) Functional Neural Differentiation of Human Adipose Tissue-Derived Stem Cells Using bFGF and Forskolin. BMC Molecular and Cell Biology, 11, Article No. 25. https://doi.org/10.1186/1471-2121-11-25

[85] Feng, N., Han, Q., Li, J., Wang, S., Li, H., Yao, X., et al. (2014) Generation of Highly Purified Neural Stem Cells from Human Adipose-Derived Mesenchymal Stem Cells by Sox1 Activation. Stem Cells and Development, 23, 515-529. https://doi.org/10.1089/scd.2013.0263

[86] Yu, J.H., Kim, M.-S., Lee, M.-Y., Lee, J.Y., Seo, J.H and Cho, S.-R. (2014) GABAergic Neuronal Differentiation Induced by Brain-Derived Neurotrophic Factor in $\mathrm{Hu}$ man Mesenchymal Stem Cells. Animal Cells and Systems (SeouI), 18, 17-24.

http://www.tandfonline.com/doi/abs/10.1080/19768354.2013.877076 https://doi.org/10.1080/19768354.2013.877076

[87] Jahan, S., Kumar, D., Kumar, A., Rajpurohit, C.S., Singh, S., Srivastava, A., et al. (2017) Neurotrophic Factor Mediated Neuronal Differentiation of Human Cord Blood Mesenchymal Stem Cells and Their Applicability to Assess the Developmental Neurotoxicity. Biochemical and Biophysical Research Communications, 482, 961-967. https://doi.org/10.1016/j.bbrc.2016.11.140

[88] Sanchez-Ramos, J., Song, S., Cardozo-Pelaez, F., Hazzi, C., Stedeford, T., Willing, A., et al. (2000) Adult Bone Marrow Stromal Cells Differentiate into Neural Cells in Vitro. Experimental Neurology, 164, 247-256.

https://pubmed.ncbi.nlm.nih.gov/10915564/

https://doi.org/10.1006/exnr.2000.7389

[89] Joannides, A., Gaughwin, P., Scott, M., Watt, S., Compston, A and Chandran, S. (2003) Postnatal Astrocytes Promote Neural Induction from Adult Human Bone Marrow-Derived Stem Cells. Journal of Hematotherapy and Stem Cell Research, 12, 681-688. https://pubmed.ncbi.nlm.nih.gov/14977477/ https://doi.org/10.1089/15258160360732704

[90] Fu, Y.-S., Shih, Y.-T., Cheng, Y.-C and Min, M.-Y. (2004) Transformation of Human Umbilical Mesenchymal Cells into Neurons in Vitro. Journal of Biomedical Science, 11, 652-660. https://link.springer.com/article/10.1007/BF02256131 https://doi.org/10.1007/BF02256131

[91] Fu, Y.-S., Cheng, Y.-C., Lin, M.-Y.A., Cheng, H., Chu, P.-M., Chou, S.-C., et al. (2006) Conversion of Human Umbilical Cord Mesenchymal Stem Cells in Wharton's Jelly to Dopaminergic Neurons In Vitro: Potential Therapeutic Application for Parkinsonism. Stem Cells, 24, 115-124.

https://stemcellsjournals.onlinelibrary.wiley.com/doi/full/10.1634/stemcells.2005-0053 https://doi.org/10.1634/stemcells.2005-0053

[92] Zurita, M., Vaquero, J., Oya, S and Miguel, M. (2005) Schwann Cells Induce Neuronal Differentiation of Bone Marrow Stromal Cells. Neuroreport, 16, 505-508. http://journals.lww.com/00001756-200504040-00017 
https://doi.org/10.1097/00001756-200504040-00017

[93] Zurita, M., Vaquero, J., Oya, S., Bonilla, C and Aguayo, C. (2007) Neurotrophic Schwann-Cell Factors Induce Neural Differentiation of Bone Marrow Stromal Cells. Neuroreport, 18, 1713-1717. http://journals.lww.com/00001756-200710290-00016 https://doi.org/10.1097/WNR.0b013e3282f0d3b0

[94] Krampera, M., Marconi, S., Pasini, A., Galiè, M., Rigotti, G., Mosna, F., et al. (2007) Induction of Neural-Like Differentiation in Human Mesenchymal Stem Cells Derived from Bone Marrow, Fat, Spleen and Thymus. Bone, 40, 382-390.

https://pubmed.ncbi.nlm.nih.gov/17049329/

https://doi.org/10.1016/j.bone.2006.09.006

[95] Wislet-Gendebien, S., Hans, G., Leprince, P., Rigo, J.-M., Moonen, G. and Rogister, B. (2005) Plasticity of Cultured Mesenchymal Stem Cells: Switch from Nestin-Positive to Excitable Neuron-Like Phenotype. Stem Cells, 23, 392-402.

https://stemcellsjournals.onlinelibrary.wiley.com/doi/full/10.1634/stemcells.2004-0149 https://doi.org/10.1634/stemcells.2004-0149

[96] Lo Furno, D., Mannino, G., Giuffrida, R., Gili, E., Vancheri, C., Tarico, M.S., et al. (2018) Neural Differentiation of Human Adipose-Derived Mesenchymal Stem Cells Induced by Glial Cell Conditioned Media. Journal of Cellular Physiology, 233, 7091-7100. https://doi.org/10.1002/jcp.26632

[97] Wei, Z.J., Fan, B.Y., Liu, Y., Ding, H., Tang, H.S., Pan, D.Y., et al. (2019) MicroRNA Changes of Bone Marrow-Derived Mesenchymal Stem Cells Differentiated into Neuronal-Like Cells by Schwann Cell-Conditioned Medium. Neural Regeneration Research, 14, 1462-1469. https://doi.org/10.4103/1673-5374.253532

[98] Jia, Y., Sun, J., Zhou, Y., Zhu, X., Zhang, B. and Lian, Y. (2007) Effects of Notch-1 Signalling Pathway on Differentiation of Marrow Mesenchymal Stem Cells into Neurons in Vitro. Neuroreport, 18, 1443-1447. https://doi.org/10.1097/WNR.0b013e3282ef7753

[99] Trzaska, K.A., Reddy, B.Y., Munoz, J.L., Li, K.Y., Ye, J.H and Rameshwar, P. (2008) Loss of RE-1 Silencing Factor in Mesenchymal Stem Cell-Derived Dopamine Progenitors Induces Functional Maturity. Molecular and Cellular Neuroscience, 39, 285-290. https://pubmed.ncbi.nlm.nih.gov/18691653/

https://doi.org/10.1016/j.mcn.2008.07.006

[100] Yang, Y., Li, Y., Lv, Y., Zhang, S., Chen, L., Bai, C., et al. (2008) NRSF Silencing Induces Neuronal Differentiation of Human Mesenchymal Stem Cells. Experimental Cell Research, 314, 2257-2265. https://pubmed.ncbi.nlm.nih.gov/18570921/ https://doi.org/10.1016/j.yexcr.2008.04.008

[101] Barzilay, R., Ben-Zur, T., Bulvik, S., Melamed, E and Offen, D. (2009) Lentiviral Delivery of $L M X 1$ a Enhances Dopaminergic Phenotype in Differentiated Human Bone Marrow Mesenchymal Stem Cells. Stem Cells and Development, 18, 591-602. https://doi.org/10.1089/scd.2008.0138

[102] Yan, M., Sun, M., Zhou, Y., Wang, W., He, Z., Tang, D., et al. (2013) Conversion of Human Umbilical Cord Mesenchymal Stem Cells in Wharton's Jelly to Dopamine Neurons Mediated by the Lmxla and Neurturin In Vitro: Potential Therapeutic Application for Parkinson's Disease in a Rhesus Monkey Model. PLoS ONE, 8, e0242032. https://doi.org/10.1371/journal.pone.0064000

[103] Wang, S., Kan, Q., Sun, Y., Han, R., Zhang, G., Peng, T., et al. (2013) Caveolin-1 Regulates Neural Differentiation of Rat Bone Mesenchymal Stem Cells into Neurons by Modulating Notch Signaling. International Journal of Developmental Neuroscience, 31, 30-35. https://pubmed.ncbi.nlm.nih.gov/23031836/ https://doi.org/10.1016/j.ijdevneu.2012.09.004 
[104] Park, H.-W., Cho, J.-S., Park, C.-K., Jung, S.J., Park, C.-H., Lee, S.-J., et al. (2012) Directed Induction of Functional Motor Neuron-Like Cells from Genetically Engineered Human Mesenchymal Stem Cells. PLoS ONE, 7, e35244. https://doi.org/10.1371/journal.pone.0035244

[105] Dezawa, M., Kanno, H., Hoshino, M., Cho, H., Matsumoto, N., Itokazu, Y., et al. (2004) Specific Induction of Neuronal Cells from Bone Marrow Stromal Cells and Application for Autologous Transplantation. Journal of Clinical Investigation, 113, 1701-1710. https://doi.org/10.1172/JCI200420935

[106] Liu, Q., Cheng, G., Wang, Z., Zhan, S., Xiong, B and Zhao, X. (2015) Bone Marrow-Derived Mesenchymal Stem Cells Differentiate into Nerve-Like Cells in Vitro after Transfection with Brain-Derived Neurotrophic Factor Gene. In Vitro Cellular \& Developmental Biology-Animal, 51, 319-327. https://doi.org/10.1007/s11626-015-9875-1

[107] Jing, L., Jya, Y., Lu, J., Han, R., Li, J., Wang, S., et al. (2011) MicroRNA-9 Promotes Differentiation of Mouse Bone Mesenchymal Stem Cells into Neurons by Notch Signaling. Neuroreport, 22, 206-211. https://pubmed.ncbi.nlm.nih.gov/21346646/ https://doi.org/10.1097/WNR.0b013e328344a666

[108] Wu, R., Wang, N., Li, M., Zang, W and Xu, Y. (2013) Experimental Study on the Facilitative Effects of miR-125b on the Differentiation of Rat Bone Marrow Mesenchymal Stem Cells into Neuron-Like Cells. Cell Biology International, 37, 812-819. http://doi.wiley.com/10.1002/cbin.10103 https://doi.org/10.1002/cbin.10103

[109] Duan, P., Sun, S., Li, B., Huang, C., Xu, Y., Han, X., et al. (2014) miR-29a Modulates Neuronal Differentiation through Targeting REST in Mesenchymal Stem Cells. PLOS ONE, 9, e97684. https://doi.org/10.1371/journal.pone.0097684

[110] Han, L., Wang, Y., Wang, L., Guo, B., Pei, S and Jia, Y. (2018) MicroRNA let-7f-5p Regulates Neuronal Differentiation of Rat Bone Marrow Mesenchymal Stem Cells by Targeting Par6a. Biochemical and Biophysical Research Communications, 495, 1476-1481. https://doi.org/10.1016/j.bbrc.2017.11.024

[111] Takeda, Y.S and Xu, Q. (2015) Neuronal Differentiation of Human Mesenchymal Stem Cells Using Exosomes Derived from Differentiating Neuronal Cells. PLoS ONE, 10, e0135111. https://doi.org/10.1371/journal.pone.0135111

[112] Alexanian, A.R., Liu, Q.S and Zhang, Z. (2013) Enhancing the Efficiency of Direct Reprogramming of Humanmesenchymal Stem Cells into Mature Neuronal-Like Cells with Thecombination of Small Molecule Modulators of Chromatin Modifyingenzymes, SMAD Signaling and Cyclic Adenosine Monophosphate Levels. International Journal of Biochemistry and Cell Biology, 45, 1633-1638.

https://pubmed.ncbi.nlm.nih.gov/23665234/

https://doi.org/10.1016/j.biocel.2013.04.022

[113] Madhu, V., Dighe, A.S., Cui, Q and Deal, D.N. (2016) Dual Inhibition of Activin/Nodal/TGF- $\beta$ and BMP Signaling Pathways by sb431542 and Dorsomorphin Induces Neuronal Differentiation of Human Adipose Derived Stem Cells. Stem Cells International, 2016, Article ID: 1035374.

https://doi.org/10.1155/2016/1035374

[114] Park, J., Lee, N., Lee, J., Choe, E.K., Kim, M.K., Lee, J., et al. (2017) Small Molecule-Based Lineage Switch of Human Adipose-Derived Stem Cells into Neural Stem Cells and Functional GABAergic Neurons. Scientific Reports, 7, Article No. 10166. https://app.dimensions.ai/details/publication/pub.1091356686 https://doi.org/10.1038/s41598-017-10394-y 
[115] Hu, Y., Li, X., Huang, G., Wang, J. and Lu, W. (2019) Fasudil May Induce the Differentiation of Bone Marrow Mesenchymal Stem Cells into Neuron-Like Cells via the Wnt/ $\beta$-Catenin Pathway. Molecular Medicine Reports, 19, 3095-3104.

https://pubmed.ncbi.nlm.nih.gov/30816472/

https://doi.org/10.3892/mmr.2019.9978

[116] Sanchez-Ramos, J.R., Song, S., Kamath, S.G., Zigova, T., Willing, A., Cardozo-Pelaez, F., et al. (2001) Expression of Neural Markers in Human Umbilical Cord Blood. Experimental Neurology, 171, 109-115.

https://linkinghub.elsevier.com/retrieve/pii/S0014488601977489 https://doi.org/10.1006/exnr.2001.7748

[117] Locatelli, F., Corti, S., Donadoni, C., Guglieri, M., Capra, F., Strazzer, S., et al. (2003) Neuronal Differentiation of Murine Bone Marrow Thy-1- and Sca-1-Positive Cells. Journal of Hematotherapy \& Stem Cell Research, 12, 727-734. https://doi.org/10.1089/15258160360732740

[118] Kondo, T., Johnson, S.A., Yoder, M.C., Romand, R and Hashino, E. (2005) Sonic Hedgehog and Retinoic Acid Synergistically Promote Sensory Fate Specification from Bone Marrow-Derived Pluripotent Stem Cells. Proceedings of the National Academy of Sciences of the United States of America, 102, 4789-4794. https://doi.org/10.1073/pnas.0408239102

[119] Cho, K.J., Trzaska, K.A., Greco, S.J., McArdle, J., Wang, F.S., Ye, J.-H., et al. (2005) Neurons Derived from Human Mesenchymal Stem Cells Show Synaptic Transmission and Can Be Induced to Produce the Neurotransmitter Substance P by Interleukin-1a. Stem Cells, 23, 383-391.

https://stemcellsjournals.onlinelibrary.wiley.com/doi/full/10.1634/stemcells.2004-0251 https://doi.org/10.1634/stemcells.2004-0251

[120] Hermann, A., List, C., Habisch, H.J., Vukicevic, V., Ehrhart-Bornstein, M., Brenner, R., et al. (2010) Age-Dependent Neuroectodermal Differentiation Capacity of Human Mesenchymal Stromal Cells: Limitations for Autologous Cell Replacement Strategies. Cytotherapy, 12, 17-30. https://pubmed.ncbi.nlm.nih.gov/19878082/ https://doi.org/10.3109/14653240903313941

[121] Hermann, A., Liebau, S., Gastl, R., Fickert, S., Habisch, H.-J., Fiedler, J., et al. (2006) Comparative Analysis of Neuroectodermal Differentiation Capacity of Human Bone Marrow Stromal Cells Using Various Conversion Protocols. Journal of Neuroscience Research, 83, 1502-1514. http://doi.wiley.com/10.1002/jnr.20840 https://doi.org/10.1002/jnr.20840

[122] Gong, M., Bi, Y., Jiang, W., Zhang, Y., Chen, L., Hou, N., et al. (2013) Retinoic Acid Receptor Beta Mediates All-Trans Retinoic Acid Facilitation of Mesenchymal Stem Cells Neuronal Differentiation. International Journal of Biochemistry and Cell Biology, 45, 866-875. https://doi.org/10.1016/j.biocel.2013.01.002

[123] Wang, N., Xu, Y., Qin, T., Wang, F.P., Ma, L.L., Luo, X.G., et al. (2013) Myocardin-Related Transcription Factor-A Is a Key Regulator in Retinoic Acid-Induced Neural-Like Differentiation of Adult Bone Marrow-Derived Mesenchymal Stem Cells. Gene, 523, 178-186. https://doi.org/10.1016/j.gene.2013.03.043

[124] Gao, Y., Bai, C., Wang, K., Sun, B., Guan, W and Zheng, D. (2014) All-Trans Retinoic Acid Promotes Nerve Cell Differentiation of Yolk Sac-Derived Mesenchymal Stem Cells. Applied Biochemistry and Biotechnology, 174, 682-692.

http://link.springer.com/10.1007/s12010-014-1100-2

https://doi.org/10.1007/s12010-014-1100-2

[125] Lu, W., Duan, D., Ackbarkhan, Z., Lu, M and Huang, M.L. (2017) Differentiation of Human Olfactory Mucosa Mesenchymal Stem Cells into Photoreceptor Cells in Vitro. International Journal of Ophthalmology, 10, 1504-1509. 


\section{Supplementary Material: Chemicals Compounds}

Table S1. Breakdown of publications in which antioxidants are used to induce neuronal differentiation of MSCs.

\begin{tabular}{|c|c|c|c|c|c|c|c|}
\hline Inductor & $\begin{array}{l}\text { Origin of } \\
\text { MSCs }\end{array}$ & Steps & Time & $\begin{array}{l}\text { Percentage of } \\
\text { differentiation } \\
\text { reported }\end{array}$ & $\begin{array}{l}\text { Technique used to } \\
\text { demonstrate } \\
\text { differentiation }\end{array}$ & $\begin{array}{l}\text { Functionality } \\
\text { demonstration }\end{array}$ & Reference \\
\hline$\beta$-Me & $\begin{array}{l}\text { Adult } \\
\text { human } \\
\text { bone } \\
\text { marrow }\end{array}$ & $\begin{array}{l}\text { Pre-induction } \\
\text { in DMEM/SFB } \\
\text { medium } 20 \% \\
\text { and } \beta \text {-Me } 1 \\
\text { mM for } 24 \mathrm{~h} \text {. } \\
\text { Subsequent } \\
\text { induction with } \\
\beta \text {-Me } 10 \mathrm{mM} \text {. }\end{array}$ & 5 hours & $\begin{array}{l}50 \% \text { demonstrated } \\
\text { by morphological } \\
\text { changes of neuronal } \\
\text { nature (cytoplasm } \\
\text { contraction, neurite } \\
\text { extension, } \\
\text { secondary } \\
\text { branching). }\end{array}$ & $\begin{array}{l}\text { Neuronal morphology was } \\
\text { observed under a } \\
\text { microscope.Increased } \\
\text { expression of NF-M and } \\
\text { NSE by } \\
\text { RT-PCR.Immunostaining } \\
\text { for NSE. }\end{array}$ & No & [54] \\
\hline $\begin{array}{l}\beta \text {-Me and } \\
\text { RA. }\end{array}$ & $\begin{array}{l}\text { Adult } \\
\text { human } \\
\text { bone } \\
\text { marrow }\end{array}$ & $\begin{array}{l}\text { Pre-induction } \\
\text { in DMEM/SFB } \\
\text { medium } 20 \% \text {, } \\
\beta \text {-Me } 10^{-3} \mathrm{M} \\
\text { and RA } 5 \times \\
10^{-7} \mathrm{M} \text { per } 24 \\
\text { h. Subsequent } \\
\text { induction by } \\
\text { serum } \\
\text { depletion. }\end{array}$ & 5 hours & $\begin{array}{l}98 \% \text { demonstrated } \\
\text { by positive } \\
\text { immunofluorescenc } \\
\text { e for NeuN and } \\
\beta \text {-tubulin III. }\end{array}$ & $\begin{array}{l}\text { Neuronal morphology was } \\
\text { observed under a } \\
\text { microscope.Expression of } \\
\text { Novo de Tau and NF-H } \\
\text { and increased expression } \\
\text { of NSE and NeuN by } \\
\text { RT-PCR.Increase nestin, } \\
\text { NSE, NeuN, and Tuj-1 } \\
\text { post-induction by } \\
\text { WB.Immunostaining for } \\
\text { NSE, NeuN, and Tuj1. }\end{array}$ & $\begin{array}{l}\text { Presence of } \mathrm{Na}^{+} \\
\text {current and } \mathrm{K}^{+} \\
\text {post-treatment } \\
\text { current } \\
\text { demonstrated by } \\
\text { Patch-clamp. } \\
\text { Increase intracellular } \\
\mathrm{Ca}^{2+} \text { concentration } \\
\text { when challenged } \\
\text { with glutamate or } \\
\text { potassium }\left(\mathrm{K}^{+}\right) \text {. }\end{array}$ & {$[56]$} \\
\hline$\beta-\mathrm{Me}$ & $\begin{array}{l}\text { Adipose } \\
\text { tissue of } \\
\text { adult } \\
\text { humans }\end{array}$ & $\begin{array}{l}\text { Pre-induction } \\
\text { in DMEM/SFB } \\
\text { medium } 20 \% \\
\text { and } \beta \text {-Me } 1 \\
\text { mM for } 24 \mathrm{~h} \text {. } \\
\text { Subsequent } \\
\text { induction with } \\
\beta \text {-Me } 10 \mathrm{mM} \text {. }\end{array}$ & 9 hours & $\begin{array}{l}70 \% \text { demonstrated } \\
\text { by morphological } \\
\text { changes of neuronal } \\
\text { nature. }\end{array}$ & $\begin{array}{l}\text { Neuronal morphology was } \\
\text { observed under a } \\
\text { microscope.Increased } \\
\text { expression of NSE, NeuN, } \\
\text { and nestin by } \\
\text { RT-PCR.Immunostaining } \\
\text { for NSE.Increase in NSE } \\
\text { per WB. }\end{array}$ & No & [55] \\
\hline$\beta$-Me & $\begin{array}{l}\text { The bone } \\
\text { marrow of } \\
\text { adult } \\
\text { Sprague } \\
\text { Dawley } \\
\text { rats. }\end{array}$ & $\begin{array}{l}\text { Pre-induction } \\
\text { in DMEM/SFB } \\
\text { medium } 20 \% \\
\text { and } \beta \text {-Me } 1 \\
\text { mM for } 24 \mathrm{~h} \text {. } \\
\text { Subsequent } \\
\text { induction with } \\
\beta \text {-Me } 10 \mathrm{mM} \text {. }\end{array}$ & 3 hours & $\begin{array}{l}40 \% \text { demonstrated } \\
\text { by morphological } \\
\text { changes of neuronal } \\
\text { nature. }\end{array}$ & $\begin{array}{l}\text { Neuronal morphology was } \\
\text { observed under a } \\
\text { microscope.Increased } \\
\text { expression of Map2, Nefl, } \\
\text { Tau, and Nestin by } \\
\text { RT-PCR.Positive } \\
\text { immunostaining for } \\
\text { nestin, tuj1, Nef, and Flk. }\end{array}$ & No & [57] \\
\hline$\beta-\mathrm{Me}$ & $\begin{array}{l}\text { The bone } \\
\text { marrow of } \\
\text { adult } \\
\text { Sprague } \\
\text { Dawley } \\
\text { rats }\end{array}$ & $\begin{array}{l}\text { Pre-induction } \\
\text { in DMEM/SFB } \\
\text { medium } 20 \% \\
\text { and } \beta \text {-Me } 1 \\
\text { mM for } 24 \text { h. } \\
\text { Subsequent } \\
\text { induction with } \\
\beta \text {-Me } 5 \text { mM. }\end{array}$ & 5 hours & $\begin{array}{l}70 \% \text { demonstrated } \\
\text { by morphological } \\
\text { changes of neuronal } \\
\text { nature. }\end{array}$ & $\begin{array}{l}\text { Neuronal morphology was } \\
\text { observed under a } \\
\text { microscope. Increase in } \\
\text { NSE and nestin and } \\
\text { decrease in Notch1 and } \\
\text { Hes1 by } \\
\text { WBImmunostaining for } \\
\text { NSE. }\end{array}$ & No & [7] \\
\hline
\end{tabular}




\section{Continued}

\begin{tabular}{|c|c|c|c|c|c|c|}
\hline $\begin{array}{l}\text { BHA/ } \\
\text { DMSO }\end{array}$ & $\begin{array}{l}\text { Human } \\
\text { umbilical } \\
\text { cordfetal }\end{array}$ & $\begin{array}{l}\text { Pre-induction } \\
\text { in DMEM/SFB } \\
\text { medium } 20 \% \\
\text { and } \beta \text {-Me } 3 \\
\text { mM for } 24 \text { h. } \\
\text { Subsequent } \\
\text { induction } \\
\text { with2\% DMSO } \\
\text { and BHA200 } \\
\mu \mathrm{M} \text {. }\end{array}$ & 8 hours & $\begin{array}{l}70 \% \text { demonstrated } \\
\text { by morphological } \\
\text { changes of neuronal } \\
\text { nature. } 71.4 \% \text { and } \\
73.2 \% \text { were } \\
\text { demonstrated by } \\
\text { positive } \\
\text { immunofluorescenc } \\
\text { e for NSE and NF, } \\
\text { respectively. }\end{array}$ & $\begin{array}{l}\text { Neuronal morphology was No } \\
\text { observed under a } \\
\text { microscope-immunostai } \\
\text { ning for NSE and } \\
\text { NF.Presence of Nissl } \\
\text { bodies by staining with } \\
\text { toluidine blue. }\end{array}$ & [58] \\
\hline $\begin{array}{l}\text { BHA/ } \\
\text { DMSO }\end{array}$ & $\begin{array}{l}\text { Adult } \\
\text { human } \\
\text { bone } \\
\text { marrow }\end{array}$ & $\begin{array}{l}\text { Pre-induction } \\
\text { in DMEM/SFB } \\
\text { medium } 20 \% \\
\text { and } \beta \text {-Me } 1 \\
\text { mM for } 24 \mathrm{~h} \text {. } \\
\text { Subsequent } \\
\text { induction with } \\
2 \% \text { DMSO and } \\
\text { BHA200 } \mu \mathrm{M} \text {. }\end{array}$ & 7 days. & $\begin{array}{l}90 \%, 88 \% \text {, and } 90 \% \\
\text { were demonstrated } \\
\text { by positive } \\
\text { immunofluorescenc } \\
\text { e for NSE, NF-200, } \\
\text { and } \beta \text {-tubulin III, } \\
\text { respectively. }\end{array}$ & $\begin{array}{l}\text { Neuronal morphology was No } \\
\text { observed under a } \\
\text { microscope. } \\
\text { Immunostaining for NSE, } \\
\text { NF-200, and B-III }\end{array}$ & [59] \\
\hline TMP & $\begin{array}{l}\text { Human } \\
\text { umbilical } \\
\text { cordFetal }\end{array}$ & $\begin{array}{l}\text { Induction with } \\
4.67 \mathrm{mg} / \mathrm{ml} \text { of } \\
\text { TMP. }\end{array}$ & $\begin{array}{l}90 \\
\text { minutes }\end{array}$ & $\begin{array}{l}85 \% \text { demonstrated } \\
\text { by morphological } \\
\text { changes of neuronal } \\
\text { nature. } 80.8 \% \text { and } \\
79.8 \% \text { were } \\
\text { demonstrated by } \\
\text { positive } \\
\text { immunofluorescence } \\
\text { for NF-H and NSE, } \\
\text { respectively. }\end{array}$ & $\begin{array}{l}\text { Neuronal morphology was No } \\
\text { observed under a } \\
\text { microscope. Novo } \\
\text { expression of NF-H and } \\
\text { NSE by RT-PCR. } \\
\text { Immunostaining for NF-H } \\
\text { and NSE and by WB. }\end{array}$ & [60] \\
\hline
\end{tabular}

Table S2. Breakdown of publications using substances that increase cAMP levels to induce neuronal differentiation of MSCs.

\begin{tabular}{|c|c|c|c|c|c|c|c|}
\hline Inductor & $\begin{array}{l}\text { Origin of } \\
\text { MSCs }\end{array}$ & Steps & Time & $\begin{array}{l}\text { Percentage of } \\
\text { differentiation } \\
\text { reported }\end{array}$ & $\begin{array}{l}\text { Technique used to } \\
\text { demonstrate } \\
\text { differentiation }\end{array}$ & $\begin{array}{l}\text { Functionality } \\
\text { demonstration }\end{array}$ & Reference \\
\hline $\begin{array}{l}\text { Isobutyl } \\
\text { methylxant } \\
\text { hine and } \\
\text { cyclic AMP } \\
\text { dibutyryl }\end{array}$ & $\begin{array}{l}\text { Adult } \\
\text { human } \\
\text { bone } \\
\text { marrow }\end{array}$ & $\begin{array}{l}\text { Induction with } \\
\text { IBMX } 0.5 \\
\text { mM/dbcAMP } 1 \\
\text { mM. }\end{array}$ & 6 days & $\begin{array}{l}25 \% \text { demonstrated } \\
\text { by morphological } \\
\text { changes of neuronal } \\
\text { nature. }\end{array}$ & $\begin{array}{l}\text { Neuronal morphology was } \\
\text { observed under a } \\
\text { microscope. } \\
\text { NSE increase per WB. }\end{array}$ & No & [61] \\
\hline $\begin{array}{l}\text { IBMX, } \\
\text { indomethac } \\
\text { in, and } \\
\text { insulin. }\end{array}$ & $\begin{array}{l}\text { Adipose } \\
\text { tissue of } \\
\text { adult } \\
\text { humans. }\end{array}$ & $\begin{array}{l}\text { Induction with } \\
5 \mathrm{~g} / \mathrm{ml} \text { of } \\
\text { insulin, } 200 \mathrm{M} \\
\text { of } \\
\text { indomethacin, } \\
\text { and isobutyl } \\
\text { methylxanthine } \\
0.5 \mathrm{mM} \text {. }\end{array}$ & 14 days & $\begin{array}{l}25 \% \text { demonstrated } \\
\text { by morphological } \\
\text { changes of neuronal } \\
\text { nature. }\end{array}$ & $\begin{array}{l}\text { Neuronal morphology was } \\
\text { observed under a } \\
\text { microscope. } \\
\text { Increase NSE and trk-A } \\
\text { by WB. } \\
\text { Immunostaining for NSE, } \\
\text { trk-A, and NeuN }\end{array}$ & $\begin{array}{l}\text { Presence of } \\
\text { voltage-gated } \\
\text { external currents } \\
\text { and late rectifier } \mathrm{K}^{+} \\
\text {currents } \\
\text { demonstrated by } \\
\text { Patch-clamp. }\end{array}$ & [62] \\
\hline
\end{tabular}




\section{Continued}

\begin{tabular}{|c|c|c|c|c|c|c|}
\hline $\begin{array}{l}\text { dbAMPc, } \\
\text { IBMX, } \\
\text { EGF, bFGF, } \\
\text { FGF-8 and } \\
\text { BDNF. }\end{array}$ & $\begin{array}{l}\text { Human } \\
\text { bone } \\
\text { marrow } \\
\text { adult }\end{array}$ & $\begin{array}{l}\text { Induction with } \\
1 \mathrm{mM} \\
\text { dbcAMP, } 0.5 \\
\mathrm{mM} \text { IBMX, } 20 \\
\mathrm{ng} / \mathrm{ml} \mathrm{hEGF} \text {, } \\
40 \mathrm{ng} / \mathrm{ml} \\
\mathrm{bFGF}, 10 \\
\mathrm{ng} / \mathrm{ml} \mathrm{FGF-8} \\
\text { and } 10 \mathrm{ng} / \mathrm{ml} \\
\text { BDNF. }\end{array}$ & 6 days & $\begin{array}{l}90 \% \text { demonstrated } \\
\text { by positive } \\
\text { immunofluorescenc } \\
\text { e for Tuj1 and } \\
\text { nestin }\end{array}$ & $\begin{array}{l}\text { Neuronal morphology was No } \\
\text { observed under a } \\
\text { microscope. } \\
\text { RT-PCR increased } \\
\text { expression of NF, NeuN, } \\
\text { Tau, Nurr1, GABA, GalC, } \\
\text { and GFAP. } \\
\text { Immunostaining for tuj1, } \\
\text { nestin, NeuN, NF, Gaba, } \\
\text { Tau, and Nurr } 1 \text { and } \\
\text { GFAP and Gal-C in cells } \\
\text { with glial morphology. }\end{array}$ & [63] \\
\hline $\begin{array}{l}\text { IBMX, RA, } \\
\text { dbAMPc, } \\
\text { NGF- } \beta \text { and } \\
\text { bFGF. }\end{array}$ & $\begin{array}{l}\text { Human } \\
\text { umbilical } \\
\text { cord } \\
\text { Fetal }\end{array}$ & $\begin{array}{l}\text { Induction with } \\
0.5 \mathrm{mM} \text { IBMX, } \\
10^{-5} \mathrm{M} \mathrm{RA}, 1 \\
\mathrm{mM} \mathrm{db}-\mathrm{cAMP}, \\
50 \mathrm{ng} / \mathrm{ml} \\
\mathrm{NGF}-\beta \text { and } 20 \\
\mathrm{ng} / \mathrm{ml} \text { bFGF. }\end{array}$ & $\begin{array}{l}48 \\
\text { hours }\end{array}$ & $\begin{array}{l}25 \% \text { demonstrated } \\
\text { by morphological } \\
\text { changes of neuronal } \\
\text { nature. }\end{array}$ & $\begin{array}{l}\text { Neuronal morphology was No } \\
\text { observed under a } \\
\text { microscope. } \\
\text { RT-PCR increased } \\
\text { Nurr-1, NF-M, NSE, } \\
\text { GFAP, Nurr1, and TH. } \\
\text { Presence of Tau, NSE, } \\
\text { GFAP, and TH by WB. } \\
\text { Immunostaining for } \\
\text { synaptophysin and HT. }\end{array}$ & [64] \\
\hline DbAMPc & $\begin{array}{l}\text { The adult } \\
\text { human } \\
\text { olfactory } \\
\text { epithelium }\end{array}$ & $\begin{array}{l}\text { Induction with } \\
\text { Db-cAMP } 2 \\
\mathrm{mM} \text { in private } \\
\text { serum } \\
\text { medium. }\end{array}$ & $\begin{array}{l}24 \\
\text { hours }\end{array}$ & $\begin{array}{l}90 \% \text { and } 20 \% \text { were } \\
\text { demonstrated by } \\
\text { positive } \\
\text { immunofluorescenc } \\
\text { e for Tuj1 and } \\
\text { OMP, respectively. }\end{array}$ & $\begin{array}{ll}\text { Neuronal morphology was } & \text { Presence of Ca } 2+ \\
\text { observed under a } & \text { currents operated } \\
\text { microscope. } & \text { by voltage } \\
\text { Immunostaining for } & \text { demonstrated by } \\
\text { OMP, Tuj1, nestin, GFAP, Patch-clamp. } \\
\text { and Neun. }\end{array}$ & [65] \\
\hline $\begin{array}{l}\text { Forskolin } \\
\text { and IBMX }\end{array}$ & $\begin{array}{l}\text { Human } \\
\text { umbilical } \\
\text { cord } \\
\text { Fetal }\end{array}$ & $\begin{array}{l}\text { Incubation } \\
\text { with forskolin } \\
10 \mu \mathrm{M} \text { AND } \\
200 \mu \mathrm{M} \text { IBMX. }\end{array}$ & $\begin{array}{l}24 \\
\text { hours }\end{array}$ & $\begin{array}{l}55 \% \text { demonstrated } \\
\text { by morphological } \\
\text { changes of neuronal } \\
\text { nature }\end{array}$ & $\begin{array}{l}\text { Neuronal morphology was No } \\
\text { observed under a } \\
\text { microscope. } \\
\text { Immunostaining for Tuj1, } \\
\text { NSE, GFAP nestin, and } \\
\text { MAP2. }\end{array}$ & [66] \\
\hline
\end{tabular}

Table S3. Breakdown of publications using chromatin modifiers to induce neuronal differentiation of MSCs.

\begin{tabular}{|c|c|c|c|c|c|c|c|}
\hline Inductor & $\begin{array}{l}\text { Origin o } \\
\text { CMMs }\end{array}$ & Steps & Time & $\begin{array}{l}\text { Percentage of } \\
\text { differentiation } \\
\text { reported }\end{array}$ & $\begin{array}{l}\text { Technique used to } \\
\text { demonstrate } \\
\text { differentiation }\end{array}$ & $\begin{array}{l}\text { Functionality } \\
\text { demonstration }\end{array}$ & Reference \\
\hline $\begin{array}{l}5 \mathrm{azadC} \text { and } \\
\text { TSA }\end{array}$ & $\begin{array}{l}\text { Balb/c } \\
\text { mouse } \\
\text { bone } \\
\text { marrow }\end{array}$ & $\begin{array}{l}\text { Pre-induction } \\
\text { with } 25 \mathrm{ng} / \mathrm{ml} \\
\text { of bFGF and } \\
\text { EGF for } 2 \text { days. } \\
\text { Subsequent } \\
\text { induction with } \\
1 \mathrm{mM} \text { of } \\
5 \text { azadC and } 40 \\
\mathrm{nM} \text { of TSA. }\end{array}$ & 2 days & $\begin{array}{l}70 \% \text { demonstrated by } \\
\text { morphological } \\
\text { changes of neuronal } \\
\text { nature }\end{array}$ & $\begin{array}{l}\text { Neuronal morphology was } \\
\text { observed under a } \\
\text { microscope. } \\
\text { Increased expression of } \\
\text { Sox } 2 \text { by RT-PCR. } \\
\text { Immunostaining for Tuj1 } \\
\text { and GFAP. }\end{array}$ & No & [67] \\
\hline
\end{tabular}




\section{Continued}

\begin{tabular}{|c|c|c|c|c|c|c|c|}
\hline $\begin{array}{l}\text { RG-108, } \\
\text { TSA, } \\
\text { 8-BrAMPc, } \\
\text { rolipram } \\
\text { and bFGF }\end{array}$ & $\begin{array}{l}\text { Human } \\
\text { bone } \\
\text { marrow } \\
\text { adult }\end{array}$ & $\begin{array}{l}\text { Induction with } \\
200 \mathrm{nM} \text { TSA, } 3 \\
\mu \mathrm{M} \text { RG-108, } \\
300 \mu \mathrm{M} \\
8 \text {-BrcAMP, } 1 \\
\mu \mathrm{M} \text { rolipram } \\
\text { and } 20 \text { ng } \\
\text { bFGF. }\end{array}$ & 3 weeks & $\begin{array}{l}44 \% \text { demonstrated by } \\
\text { positive } \\
\text { immunofluorescence } \\
\text { for MAP2. }\end{array}$ & $\begin{array}{l}\text { Neuronal morphology was } \\
\text { observed under a } \\
\text { microscope. } \\
\text { Decreased expression Oct } \\
4 \text {, Nanog, Klf4, c Myc and } \\
\text { increased Sox 2, nestin, } \\
\text { A2B5, NCAM, GFAP, } \\
\text { NeuN, MAP2, Nurr1, and } \\
\text { TH by RT-PCR. } \\
\text { Immunostaining for } \\
\text { Sox-2, nestin, A2B5, } \\
\text { NCAM, B3T, GFAP, } \\
\text { NeuN, and MAP2. }\end{array}$ & $\begin{array}{l}\text { Release of } \\
\text { dopamine to the } \\
\text { medium } \\
\text { demonstrated } \\
\text { by ELISA. }\end{array}$ & [68] \\
\hline $\begin{array}{l}\text { RG-108, } \\
\text { TSA, } \\
\text { 8-BrAMPc, } \\
\text { rolipram } \\
\text { and bFGF }\end{array}$ & $\begin{array}{l}\text { Human } \\
\text { bone } \\
\text { marrow } \\
\text { adult }\end{array}$ & $\begin{array}{l}\text { It is } \\
\text { preconditioning } \\
\text { in a hypoxic } \\
\text { environment for } \\
48 \mathrm{~h} \text {. } \\
\text { Subsequent } \\
\text { induction with } \\
200 \mathrm{nM} \text { TSA, } 3 \\
\mu \mathrm{M} \text { RG-108, } 300 \\
\mu \mathrm{M} 8 \text {-BrcAMP, } \\
1 \mu \mathrm{M} \text { rolipram, } \\
\text { and } 20 \text { ng } \\
\text { bFGF. }\end{array}$ & 3 weeks & $\begin{array}{l}50 \% \text { and } 60 \% \text { were } \\
\text { demonstrated by } \\
\text { positive } \\
\text { immunofluorescence } \\
\text { for TH and Nurr1, } \\
\text { respectively. }\end{array}$ & $\begin{array}{l}\text { Neuronal morphology was } \\
\text { observed under a } \\
\text { microscope. } \\
\text { Immunostaining for TH } \\
\text { and Nurr1 and by WB. } \\
\text { Increased expression of Sox } \\
\text { 2, nestin, A2B5, NCAM, } \\
\text { GFAP, NeuN, MAP2, } \\
\text { Nurr1, and TH by } \\
\text { RT-PCR. }\end{array}$ & $\begin{array}{l}\text { The release of } \\
\text { dopamine to the } \\
\text { medium } \\
\text { increases in the } \\
\text { presence of ATP } \\
\text { demonstrated } \\
\text { by ELISA. }\end{array}$ & [69] \\
\hline $\begin{array}{l}\text { RG-108, } \\
\text { TSA, } \\
\text { 8-BrAMPc, } \\
\text { rolipram } \\
\text { and bFGF }\end{array}$ & $\begin{array}{l}\text { Adult } \\
\text { Sprague } \\
\text { Dawley } \\
\text { rat bone } \\
\text { marrow. }\end{array}$ & $\begin{array}{l}\text { Exposure to } \\
200 \mathrm{nM} \text { TSA, } \\
10 \mu \mathrm{M} \text { RG-108, } \\
10 \mu \mathrm{M} \\
8 \text {-BrcAMP, } 1 \\
\mu \mathrm{M} \text { rolipram } \\
\text { and } 20 \mathrm{ng} \\
\text { bFGF. }\end{array}$ & 7 days & $\begin{array}{l}73.6 \% \text { indicated by } \\
\text { morphological } \\
\text { changes of neuronal } \\
\text { nature. } \\
71.6 \%, 73.3 \% \text {, and } \\
64.2 \% \text { were } \\
\text { demonstrated by } \\
\text { positive } \\
\text { immunofluorescence } \\
\text { for Tuj1, MAp2, and } \\
\text { ChAT, respectively. }\end{array}$ & $\begin{array}{l}\text { Neuronal morphology was } \\
\text { observed under a } \\
\text { microscope. } \\
\text { Immunostaining for Tuj1, } \\
\text { ChAT and MAP2 and by } \\
\text { WB. } \\
\text { Increased expression of } \\
\text { nestin, Tuj1, MAP2, and } \\
\text { ChAT by RT_PCR. }\end{array}$ & No & [70] \\
\hline
\end{tabular}

Table S4. Breakdown of publications using growth factors and/or neurotrophic factors to induce neuronal differentiation of MSCs.

\begin{tabular}{|c|c|c|c|c|c|c|c|}
\hline Inductor & $\begin{array}{l}\text { Origin of } \\
\text { CMMs }\end{array}$ & Steps & Time & $\begin{array}{l}\text { Percentage of } \\
\text { differentiation } \\
\text { reported }\end{array}$ & $\begin{array}{l}\text { Technique used to } \\
\text { demonstrate } \\
\text { differentiation }\end{array}$ & $\begin{array}{l}\text { Functionality } \\
\text { demonstration }\end{array}$ & Reference \\
\hline $\begin{array}{l}\text { bFGF and } \\
\text { EGF. }\end{array}$ & $\begin{array}{l}\text { Umbilical } \\
\text { cord and } \\
\text { bone } \\
\text { marrow of } \\
\text { human. }\end{array}$ & $\begin{array}{l}\text { Induction } \\
\text { with } 20 \mathrm{ng} / \mathrm{ml} \\
\text { bFGF and } 20 \\
\text { ng/hEGF. }\end{array}$ & 7 days & $\begin{array}{l}50 \% \text { demonstrated by } \\
\text { morphological } \\
\text { changes of neuronal } \\
\text { nature. }\end{array}$ & $\begin{array}{l}\text { Neuronal morphology was } \\
\text { observed under a } \\
\text { microscope. } \\
\text { Immunostaining for Tuj1 } \\
\text { and GFAP and by WB. }\end{array}$ & No & [72] \\
\hline
\end{tabular}




\section{Continued}

\begin{tabular}{|c|c|c|c|c|c|c|c|}
\hline $\begin{array}{l}\text { bFGF, } \\
\text { PDGF, } \\
\text { Herguline, } \\
\text { Forskolin, } \\
\text { B-Me and } \\
\text { RA }\end{array}$ & $\begin{array}{l}\text { The bone } \\
\text { marrow of } \\
\text { adult } \\
\text { Wistar rat. }\end{array}$ & $\begin{array}{l}\text { Pre-induction } \\
\text { with } \beta \text {-Me } 1 \\
\mathrm{mM} \text { and } 35 \\
\mathrm{ng} / \mathrm{ml} \text { of RA } \\
\text { for } 3 \text { days. } \\
\text { Subsequent } \\
\text { induction with } \\
\text { forskolin } 5 \\
\mathrm{mM}, \mathrm{bFGF} 10 \\
\mathrm{ng} / \mathrm{ml} \text {, PDGF } \\
5 \mathrm{ng} / \mathrm{ml} \text { and } \\
\text { heregulin } 200 \\
\mathrm{ng} / \mathrm{ml} \text {. }\end{array}$ & 7 days & $\begin{array}{l}40 \% \text { demonstrated by } \\
\text { morphological } \\
\text { changes of a glial } \\
\text { nature. }\end{array}$ & $\begin{array}{l}\text { Glial morphology was } \\
\text { observed under a } \\
\text { microscope. } \\
\text { Immunostaining for p75, } \\
\text { GFAP, O4, and S-100. }\end{array}$ & $\begin{array}{l}\text { Post-transplant } \\
\text { myelination in } \\
\text { sectioned rat } \\
\text { sciatic nerves. }\end{array}$ & [52] \\
\hline $\begin{array}{l}\text { bFGF, } \\
\text { PDGF, } \\
\text { Herguline, } \\
\text { Forskolin, } \\
\text { B-Me and } \\
\text { RA }\end{array}$ & $\begin{array}{l}\text { The } \\
\text { umbilical } \\
\text { cord of a } \\
\text { fetal } \\
\text { human. }\end{array}$ & $\begin{array}{l}\text { Pre-induction } \\
\text { with } \beta \text {-Me } 1 \\
\mathrm{mM} \text { and } 35 \\
\mathrm{ng} / \mathrm{ml} \text { of RA } \\
\text { for } 3 \text { days. } \\
\text { Subsequent } \\
\text { induction with } \\
\text { forskolin } 14 \\
\mu \mathrm{M}, \mathrm{bFGF} 10 \\
\mathrm{ng} / \mathrm{ml}, \mathrm{PDGF} \\
5 \mathrm{ng} / \mathrm{ml} \text { and } \\
\mathrm{heregulin} 200 \\
\mathrm{ng} / \mathrm{ml} \text {. }\end{array}$ & 8 days & $\begin{array}{l}68 \%, 77 \%, 75 \% \text { and } \\
72 \% \text { demonstrated by } \\
\text { positive } \\
\text { immunofluorescence } \\
\text { for } \\
\text { GFAP, p75, S100, and } \\
\text { MBP, respectively. }\end{array}$ & $\begin{array}{l}\text { Glial morphology was } \\
\text { observed under a } \\
\text { microscope. } \\
\text { Immunostaining for } \\
\text { GFAP, p75, S100, and } \\
\text { MBP. } \\
\text { Increased expression p75, } \\
\text { S100B, and GFAP by } \\
\text { RT-PCR. } \\
\text { Increase p75 and GFAP by } \\
\text { WB. }\end{array}$ & $\begin{array}{l}\text { Improvement in } \\
\text { the number and } \\
\text { length of } \\
\text { neurites when } \\
\text { cultured with } \\
\text { neurons from } \\
\text { the dorsal root } \\
\text { ganglia. }\end{array}$ & [73] \\
\hline $\begin{array}{l}\text { bFGF, } \\
\text { FGF8, and } \\
\text { BDNF }\end{array}$ & $\begin{array}{l}\text { The bone } \\
\text { marrow of } \\
\text { adult } \\
\text { Balb/c } \\
\text { mouse. }\end{array}$ & $\begin{array}{l}\text { Induction } \\
\text { with } 100 \\
\mathrm{ng} / \mathrm{ml} \mathrm{bFGF} \text {, } \\
10 \mathrm{ng} / \mathrm{ml} \\
\text { FGF- } 8 \text { and } 10 \\
\mathrm{ng} / \mathrm{ml} \mathrm{BDNF} \text {. }\end{array}$ & $\begin{array}{l}14 \\
\text { days }\end{array}$ & $\begin{array}{l}69.9 \%, 30 \% \text { and } 50 \% \\
\text { demonstrated by } \\
\text { positive } \\
\text { immunofluorescence } \\
\text { for } \\
\text { NF200, TH and } \\
\text { GABA, respectively. }\end{array}$ & $\begin{array}{l}\text { Neuronal morphology was } \\
\text { observed under a microscope. } \\
\text { Immunostaining for NF200, } \\
\text { Tau, MAP2, GFAP, Gal-C, } \\
\text { dopadecarboxylase, TH, } \\
\text { serotonin, and GABA. } \\
\text { RT-PCR increased the } \\
\text { expression of Otx2, Otx1, } \\
\text { Pax2, Pax5, Nestin, MAP2, } \\
\text { and Tau. }\end{array}$ & No & [74] \\
\hline $\begin{array}{l}\text { FGF-2, } \\
\text { EGF, RA, } \\
\text { and } \beta \text {-NGF }\end{array}$ & $\begin{array}{l}\text { Adult } \\
\text { Charles } \\
\text { River } \\
\text { mouse } \\
\text { bone } \\
\text { marrow }\end{array}$ & $\begin{array}{l}\text { Pre-induction } \\
\text { with FGF-2 } 40 \\
\mathrm{ng} / \mathrm{ml} \text { and } \\
\text { EGF } 20 \mathrm{ng} / \mathrm{ml} \\
\text { for } 7 \text { days. } \\
\text { Subsequent } \\
\text { induction with } \\
\text { RA } 0.5 \mu \mathrm{M} \\
\text { and } 20 \mathrm{ng} / \mathrm{ml} \\
\beta \text {-NGF }\end{array}$ & $\begin{array}{l}2 \\
\text { weeks }\end{array}$ & $\begin{array}{l}36 \% \text { and } 31 \% \text { were } \\
\text { demonstrated by } \\
\text { positive } \\
\text { immunofluorescence } \\
\text { for Tuj1 and TUC4, } \\
\text { respectively. }\end{array}$ & $\begin{array}{l}\text { Neuronal morphology was } \\
\text { observed under a } \\
\text { microscope. } \\
\text { Presence of Tuj1 and } \\
\text { NeuN by WB. } \\
\text { Immunostaining for B-III, } \\
\text { TUC4, NR2A, calcium } \\
\text { channel } \alpha 1 \mathrm{~A}, \mathrm{DCX}, \mathrm{NeuN}, \\
\text { MBP, GABA, } \\
\text { Synaptophysin, Glutamic } \\
\text { ac. Decarboxylase, Neuro } \\
\text { D, } \alpha 1 \mathrm{~B} \text { calcium channel, } \\
\text { nestin, GFAP, and MAP2. }\end{array}$ & No & [75] \\
\hline
\end{tabular}




\section{Continued}

\begin{tabular}{|c|c|c|c|c|c|c|c|}
\hline bFGF & $\begin{array}{l}\text { The bone } \\
\text { marrow of } \\
\text { adult } \\
\text { Balb/c } \\
\text { mouse. }\end{array}$ & $\begin{array}{l}\text { Induction } \\
\text { with bFGF } 25 \\
\mathrm{ng} / \mathrm{ml} \text {. }\end{array}$ & & $\begin{array}{l}94.5 \% .88 .5 \% \text { and } 65 \% \\
\text { were demonstrated by } \\
\text { positive } \\
\text { immunofluorescence } \\
\text { for nestin, NF-L, and } \\
\text { Tuj1. }\end{array}$ & $\begin{array}{l}\text { Neuronal morphology was } \\
\text { observed under a } \\
\text { microscope. } \\
\text { Immunostaining for NF-L } \\
\text { and Tuj1. } \\
\text { Increased expression of } \\
\text { NF-L and Tuj1 by RT-PCR. }\end{array}$ & $\begin{array}{l}\text { Increase the } \\
\text { intracellular } \\
\text { concentration } \\
\text { of } \mathrm{CA}^{2+} \text { in } \\
\text { response to } \\
\text { glutamate and } \\
\text { veratridine. }\end{array}$ & [76] \\
\hline $\begin{array}{l}\text { FGF8, } \\
\text { bFGF, and } \\
\text { Shh }\end{array}$ & $\begin{array}{l}\text { Adult } \\
\text { human } \\
\text { bone } \\
\text { marrow }\end{array}$ & $\begin{array}{l}\text { induction with } \\
250 \mathrm{ng} / \mathrm{ml} \text { of } \\
\mathrm{SHH}, 100 \\
\mathrm{ng} / \mathrm{ml} \text { of } \\
\mathrm{FGF} 8 \text {, and } 50 \\
\mathrm{ng} / \mathrm{ml} \text { of } \\
\mathrm{bFGF} \text {. }\end{array}$ & $\begin{array}{l}12 \\
\text { days }\end{array}$ & $\begin{array}{l}90 \% \text { and } 68.7 \% \text { were } \\
\text { demonstrated by } \\
\text { positive } \\
\text { immunofluorescence } \\
\text { for NeuN and } \mathrm{TH} \text {, } \\
\text { respectively. }\end{array}$ & $\begin{array}{l}\text { Neuronal morphology was } \\
\text { observed under a } \\
\text { microscope. } \\
\text { Increased expression of } \\
\text { NeuN, B-tubulin III, TH, } \\
\text { DAT, En1, En2, Wnt1, } \\
\text { Lmx1a, Nurr1, and Pitx3 } \\
\text { by RT-PCR and WB. } \\
\text { Immunostaining for TH, } \\
\text { NeuN, B-III, VMAT2, and } \\
\text { SVP2. }\end{array}$ & $\begin{array}{l}\text { ELISA } \\
\text { demonstrates } \\
\text { dopamine } \\
\text { secretion to the } \\
\text { medium that } \\
\text { increases in the } \\
\text { presence of ATP. } \\
\text { Elevation of } \\
\text { intracellular } \mathrm{Ca}^{2+} \\
\text { in the presence } \\
\text { of ATP. } \\
\text { Negative resting } \\
\text { membrane } \\
\text { potential } \\
\text { demonstrated by } \\
\text { Patch-clamp. }\end{array}$ & [77] \\
\hline $\begin{array}{l}\text { FGF8, } \\
\text { bFGF, and } \\
\text { Shh }\end{array}$ & $\begin{array}{l}\text { Bone } \\
\text { marrow } \\
\text { and } \\
\text { umbilical } \\
\text { cord of } \\
\text { human. }\end{array}$ & $\begin{array}{l}\text { Induction } \\
\text { with } 250 \\
\mathrm{ng} / \mathrm{ml} \text { of } \mathrm{SHH} \text {, } \\
100 \mathrm{ng} / \mathrm{ml} \text { of } \\
\mathrm{FGF} 8 \text {, and } 50 \\
\mathrm{ng} / \mathrm{ml} \text { of } \\
\mathrm{bFGF} \text {. }\end{array}$ & 9 days & $\begin{array}{l}\text { Bone marrow } \\
91.4 \%, 63.98 \% \text {, and } \\
62.38 \% \text { were } \\
\text { demonstrated by } \\
\text { positive } \\
\text { immunofluorescence } \\
\text { for MAP2, TH, and } \\
\text { Nurr1, respectively. } \\
\text { Umbilical cord. } \\
91.84 \%, 65.82 \% \text {, and } \\
68.9 \% \text { were } \\
\text { demonstrated by } \\
\text { positive } \\
\text { immunofluorescence } \\
\text { for MAP2, TH, and } \\
\text { Nurr1, respectively. }\end{array}$ & $\begin{array}{l}\text { Neuronal morphology was } \\
\text { observed under a } \\
\text { microscope. } \\
\text { Increased expression of } \\
\beta \text {-tubulin III, Nurr1, and } \\
\text { EN1 by RT_PCR. } \\
\text { Immunostaining for } \\
\beta \text {-tubulin III, Map2ab and } \\
\text { Kv4.2, TH, DARPP32, } \\
\text { Nurr1, PitX3, and VMAT2. }\end{array}$ & $\begin{array}{l}\text { The release of } \\
\text { dopamine to the } \\
\text { medium in a } \\
\text { constitutive way } \\
\text { increases with } \\
\text { exposure to ATP } \\
\text { in both cell } \\
\text { types, } \\
\text { demonstrated by } \\
\text { ELISA. } \\
\text { Increased } \\
\text { concentration } \\
\text { of intracellular } \\
\text { CA }{ }^{2+} \text { by } \\
\text { stimulation } \\
\text { with ATP. }\end{array}$ & [78] \\
\hline $\begin{array}{l}\text { FGF8, } \\
\text { bFGF, Shh, } \\
\text { and } \\
\text { Ascorbic } \\
\text { acid. }\end{array}$ & $\begin{array}{l}\text { The adult } \\
\text { human } \\
\text { dental pulp }\end{array}$ & $\begin{array}{l}\text { induction with } \\
250 \mathrm{ng} / \mathrm{ml} \text { of } \\
\mathrm{SHH}, 100 \\
\mathrm{ng} / \mathrm{ml} \text { of FGF8, } \\
\text { and } 50 \mathrm{ng} / \mathrm{ml} \\
\text { of bFGF for } 4 \\
\text { days and } \\
\text { subsequent } \\
\text { maintenance in } \\
\text { medium with } \\
\text { Ascorbic acid. }\end{array}$ & $\begin{array}{l}10 \\
\text { days }\end{array}$ & $\begin{array}{l}96 \% \text { and } 94.1 \% \text { were } \\
\text { demonstrated by } \\
\text { positive } \\
\text { immunofluorescence } \\
\text { for TUJ1 and MBP, } \\
\text { respectively. }\end{array}$ & $\begin{array}{l}\text { Neuronal morphology was } \\
\text { observed under a } \\
\text { microscope. } \\
\text { Immunostaining for nestin, } \\
\text { Tuj1, GFAP, MBP, and } \\
\text { TH. } \\
\text { RT-PCR increased the } \\
\text { expression of nestin, pax6, } \\
\text { Tuj1, MAP2, GFAP, MBP, } \\
\text { and TH. }\end{array}$ & No & [79] \\
\hline
\end{tabular}




\section{Continued}

SHH, Dental pulp Pre-induction 7 days

FGF-8, of human with $20 \mathrm{ng} / \mathrm{ml}$

GDNF and infant. bFGF and 20

Forskolin

EGF for one

week.

Subsequent

induction with

$200 \mathrm{ng} / \mathrm{ml}$ of

Shh, 100

ng/ml FGF8,

$10 \mathrm{ng} / \mathrm{ml}$

GDNF and

forskolin 10

$\mu \mathrm{M}$.

FGF-2 and The bone Induction

D609.

marrow of with $4 \mathrm{ng} / \mathrm{ml}$

adult of FGF-2 and

Wistar rat. $8 \mu \mathrm{g} / \mathrm{ml}$ of

D609 for 2

days.

Subsequent

maintenance

with $4 \mathrm{ng} / \mathrm{ml}$

of FGF-2.

FGF-2, Human Induction

EGF, and amniotic with FGF-2, weeks

NSF-1 fluid EGF, and

Fetal. NSF-1.

bFGF and Adipose

Forskolin tissue of

adult

humans
$70 \%$ demonstrated by

morphological

changes of neuronal

nature.

6 days $75 \%$ demonstrated by

morphological

changes of neuronal

nature.
Neuronal morphology was

observed under a

microscope.

Immunostaining for Tuj1,

$\mathrm{MAP} 2$, and $\mathrm{TH}$.

Decrease Increased

expression of MAP2 and

TH by RT-PCR.

Presence of TH by WB. dopamine to the

medium

demonstrated

by HPLC.
Neuronal morphology was Decrease in observed under a

resting

membrane

Immunostaining for NSE, potential

NF-L, and synapsin.

demonstrated

Increased expression of by Patch-clamp.

NSE and NF-L by RT-PCR.

$80 \%$ demonstrated by Neuronal morphology was Presence of $\mathrm{Na}^{+}$[83]

positive

immunofluorescence

for NSE and MAP2. observed under a

microscope.

Immunostaining for NSE TTX

and MAP2

Increased nestin

expression and GFAP

RT-PCR.

Pre-induction 7 days $75 \%$ demonstrated by

with 100

$\mathrm{ng} / \mathrm{ml}$ bFGF

for 7 days.

Subsequent

induction with

forskolin 10

$\mu \mathrm{M}$.

the presence of
voltage-gated sodium
currents.

currents.
Neuronal morphology was observed under a

microscope.

Immunostaining for

MAP2, GAP43, nestin, Tuj1, MAP2, NFL, NFM, NFH, NSE, NeuN, GFAP, and CNPase.

Increased expression

ABCG2, nestin, Tuj1, MAP2, NFL, NFM, NSE, GAP43, SCN5A, Kv4.2, EAG2, CACNAC1C, Kv4.3, SNAP25, GFAP,

and CNPase by RT-PCR. currents

sensitive to

demonstrated

by Patch-clamp.

The presence of [84]

current is $\mathrm{Na}^{+}$

TTX-sensitive

voltage

dependents,

outward $\mathrm{K}^{+}$

currents, and

prominent

negative resting

membrane

potentials

demonstrated

by Patch-clamp. 


\section{Continued}

\begin{tabular}{|c|c|c|c|c|c|c|c|}
\hline $\begin{array}{l}\text { EGF, bFGF, } \\
\text { BDNF, } \\
\text { indomethac } \\
\text { in, insulin, } \\
\text { and IBMX }\end{array}$ & $\begin{array}{l}\text { Adipose } \\
\text { tissue of } \\
\text { adult } \\
\text { Wistar rat. }\end{array}$ & $\begin{array}{l}\text { Pre-induction } \\
\text { with } 10 \mathrm{ng} / \mathrm{ml} \\
\text { of EGF, } 20 \\
\text { bFGF, and } 10 \\
\text { BDNF for } 3 \\
\text { days. } \\
\text { Subsequent } \\
\text { induction with } \\
\text { indomethacin } \\
120 \mu \mathrm{M} \text {, } \\
\text { insulin } 3 \\
\mu \mathrm{g} / \mathrm{ml} \text {, and } \\
\mathrm{IBMX} 300 \mu \mathrm{M}\end{array}$ & $\begin{array}{l}48 \\
\text { hours }\end{array}$ & $\begin{array}{l}70 \% \text { and } 75 \% \text { were } \\
\text { demonstrated by } \\
\text { positive } \\
\text { immunofluorescence } \\
\text { for Tuj1 and GFAP, } \\
\text { respectively. }\end{array}$ & $\begin{array}{l}\text { Neuronal morphology was } \\
\text { observed under a } \\
\text { microscope. } \\
\text { Immunostaining for Tuj1 } \\
\text { and GFAP and by WB. }\end{array}$ & No & [9] \\
\hline $\begin{array}{l}\text { EGF, bFGF, } \\
\text { B-Me, RA } \\
\text { and BDNF }\end{array}$ & $\begin{array}{l}\text { Adipose } \\
\text { tissue of } \\
\text { adult } \\
\text { humans }\end{array}$ & $\begin{array}{l}\text { Pre-induction } \\
\text { with } \beta \text {-me } 0.1 \\
\mathrm{mM} \text { and } 4 \\
\mathrm{ng} / \mathrm{ml} \text { of bFGF } \\
\text { for } 8 \text { days. } \\
\text { Switch to } \\
\text { medium with } \\
20 \mathrm{ng} / \mathrm{ml} \text { EGF } \\
\text { and } 20 \mathrm{ng} / \mathrm{ml} \\
\text { bFGF for } \\
\text { another } 7 \text { days. } \\
\text { Subsequent } \\
\text { terminal } \\
\text { induction with } \\
0.5 \mathrm{mM} \mathrm{RA} \\
\text { and } 10 \mathrm{ng} / \mathrm{ml} \\
\text { BDNF }\end{array}$ & $\begin{array}{l}14 \\
\text { days }\end{array}$ & $\begin{array}{l}96 \% \text { demonstrated by } \\
\text { positive } \\
\text { immunofluorescence } \\
\text { for Sox } 1, \text { pax6, and } \\
\text { nestin. }\end{array}$ & $\begin{array}{l}\text { Neuronal morphology was } \\
\text { observed under a } \\
\text { microscope. } \\
\text { Increased expression of } \\
\text { MAP2 SN5A, NE-NA, } \\
\text { MaxiK, KV4.3, KV4.2, } \\
\text { KV1.4, EAG1, EAG1, } \\
\text { CACNA1C, and } \\
\text { CACNA1G. }\end{array}$ & $\begin{array}{l}\text { Presence of } \\
\text { voltage-gated } \\
\text { sodium current } \\
\text { sensitive to } \\
\text { TTX, } \\
\text { demonstrated } \\
\text { by Patch-clamp. }\end{array}$ & [85] \\
\hline BDNF & $\begin{array}{l}\text { Adult } \\
\text { human } \\
\text { bone } \\
\text { marrow }\end{array}$ & $\begin{array}{l}\text { Induction } \\
\text { with } 50 \mathrm{ng} / \mathrm{ml} \\
\text { BDNF }\end{array}$ & 7 days & $\begin{array}{l}94.7 \% \text { and } 21.5 \% \text { were } \\
\text { demonstrated by } \\
\text { positive } \\
\text { immunofluorescence } \\
\text { for Tuj } 1 \text { and GABA, } \\
\text { respectively. }\end{array}$ & $\begin{array}{l}\text { Neuronal morphology was } \\
\text { observed under a } \\
\text { microscope. } \\
\text { Immunostaining for Tuj1 } \\
\text { and GABA. } \\
\text { Increased expression of } \\
\text { nestin, ChAT, and GAD67 } \\
\text { by RT-PCR }\end{array}$ & No & [86] \\
\hline
\end{tabular}


Table S5. Breakdown of publications in which coculture with mature neuronal cells is used to induce neuronal differentiation of MSCs.

\begin{tabular}{|c|c|c|c|c|c|c|c|}
\hline Inductor & $\begin{array}{l}\text { Origin of } \\
\text { CMMs }\end{array}$ & Steps & Time & $\begin{array}{l}\text { Percentage of } \\
\text { differentiation } \\
\text { reported }\end{array}$ & $\begin{array}{l}\text { Technique used to } \\
\text { demonstrate differentiation }\end{array}$ & $\begin{array}{l}\text { Functionality } \\
\text { demonstration }\end{array}$ & Reference \\
\hline $\begin{array}{l}\text { Coculture } \\
\text { in medium } \\
\text { conditione } \\
d \text { by } \\
\text { neurons of } \\
\text { Sprague-Da } \\
\text { wley rats. }\end{array}$ & $\begin{array}{l}\text { Fetal } \\
\text { human } \\
\text { umbilical } \\
\text { cord }\end{array}$ & $\begin{array}{l}\text { The MSCs were } \\
\text { grown in a } \\
\text { DMEM medium } \\
\text { conditioned by } \\
\text { neurons } \\
\text { extracted from } \\
\text { the brains of } \\
\text { seven-day-old } \\
\text { Sprague-Dawley } \\
\text { rats. }\end{array}$ & 12 days & $\begin{array}{l}87.4 \% \text { and } 58.2 \% \\
\text { were } \\
\text { demonstrated by } \\
\text { positive } \\
\text { immunofluoresce } \\
\text { nce for NF and } \\
\text { NeuN, } \\
\text { respectively. }\end{array}$ & $\begin{array}{l}\text { Neuronal morphology was } \\
\text { observed under a microscope. } \\
\text { Immunostaining for NeuN, } \\
\text { NF, GFAP, OX } 42 \text {, } \\
\text { parvalbumin, and calbindin. } \\
\text { Presence of GluR6, GluR7, } \\
\text { and KA2 by WB and } \\
\text { RT-PCR. }\end{array}$ & $\begin{array}{l}\text { Generation of } \\
\text { input currents } \\
\text { in response to a } \\
1 \mathrm{mM} \text { glutamate } \\
\text { bath } \\
\text { demonstrated } \\
\text { by } \\
\text { Patch-clamp. }\end{array}$ & {$[90]$} \\
\hline $\begin{array}{l}\text { Culture in } \\
\text { medium } \\
\text { conditione } \\
d \text { by } \\
\text { neurons of } \\
\text { rats } \\
\text { Sprague-Da } \\
\text { wley, Shh, } \\
\text { and FGF8 }\end{array}$ & $\begin{array}{l}\text { Human } \\
\text { umbilical } \\
\text { cord }\end{array}$ & $\begin{array}{l}\text { The MSCs were } \\
\text { grown in a } \\
\text { DMEM medium } \\
\text { conditioned by } \\
\text { neurons } \\
\text { extracted from } \\
\text { the brains of } \\
\text { seven-day-old } \\
\text { Sprague-Dawley } \\
\text { rats born for } 9 \\
\text { days. } \\
\text { Subsequently, } \\
\text { Shh } 500 \text { ng/ml } \\
\text { and FGF8 } 100 \\
\text { ng/ml were } \\
\text { added. }\end{array}$ & 6 days & $\begin{array}{l}87.4 \% \text { and } 58.2 \% \\
\text { were } \\
\text { demonstrated by } \\
\text { positive } \\
\text { immunofluoresce } \\
\text { nce for NF and } \\
\text { NeuN, } \\
\text { respectively. }\end{array}$ & $\begin{array}{l}\text { Neuronal morphology was } \\
\text { observed under a microscope. } \\
\text { Immunostaining for TH and } \\
\text { GAD. } \\
\text { Presence of TH by WB. }\end{array}$ & $\begin{array}{l}\text { Release of } \\
\text { dopamine to } \\
\text { the medium } \\
\text { demonstrated } \\
\text { by HPLC. }\end{array}$ & [91] \\
\hline $\begin{array}{l}\text { Coculture } \\
\text { with } \\
\text { Schwann } \\
\text { cells }\end{array}$ & $\begin{array}{l}\text { The bone } \\
\text { marrow } \\
\text { of adult } \\
\text { Wistar } \\
\text { rat. }\end{array}$ & $\begin{array}{l}\text { CMM and } \\
\text { Schwann cells } \\
\text { extracted from } \\
\text { the sciatic nerve } \\
\text { of adult Wistar } \\
\text { rats were } \\
\text { co-cultured. }\end{array}$ & 2 weeks & $\begin{array}{l}60 \%, 52 \% \text {, and } \\
34 \% \text { demonstrated } \\
\text { by positive } \\
\text { immunofluoresce } \\
\text { nce for NSE, } \\
\text { NF-200, and Tuj1, } \\
\text { respectively }\end{array}$ & $\begin{array}{l}\text { Neuronal morphology was } \\
\text { observed under a microscope. } \\
\text { Immunostaining for nestin, } \\
\text { NF-200, and Tuj1. }\end{array}$ & No & [92] \\
\hline $\begin{array}{l}\text { Coculture } \\
\text { with } \\
\text { Schwann } \\
\text { cells }\end{array}$ & $\begin{array}{l}\text { The bone } \\
\text { marrow } \\
\text { of adult } \\
\text { Wistar } \\
\text { rat. }\end{array}$ & $\begin{array}{l}\text { CMM and } \\
\text { Schwann cells } \\
\text { extracted from } \\
\text { the sciatic nerve } \\
\text { of adult Wistar } \\
\text { rats were } \\
\text { co-cultured in } \\
\text { transwell culture } \\
\text { plates with } \\
\text { polycarbonate } \\
\text { membrane. }\end{array}$ & 2 weeks & $\begin{array}{l}48.2 \%, 46.2 \% \text { and } \\
27.4 \% \\
\text { demonstrated by } \\
\text { positive } \\
\text { immunofluoresce } \\
\text { nce for } \\
\text { NF-200, Tuj1, and } \\
\text { GFAP, } \\
\text { respectively. }\end{array}$ & $\begin{array}{l}\text { Neuronal morphology was } \\
\text { observed under a microscope. } \\
\text { Immunostaining for nestin, } \\
\text { NF-200, Tuj1, and GFAP. } \\
\text { Increased expression nestin, } \\
\text { Tuj1, and GFAP by RT-PCR. }\end{array}$ & No & [93] \\
\hline
\end{tabular}




\section{Continued}

\begin{tabular}{|c|c|c|c|c|c|c|c|}
\hline $\begin{array}{l}\text { Co-culture } \\
\text { with } \\
\text { human } \\
\text { Schwann } \\
\text { cells }\end{array}$ & $\begin{array}{l}\text { Adipose } \\
\text { tissue of } \\
\text { adult } \\
\text { humans }\end{array}$ & $\begin{array}{l}\text { CMM was } \\
\text { co-cultured with } \\
\text { human Schwann } \\
\text { cells from benign } \\
\text { Schwannomas of } \\
\text { the acoustic } \\
\text { nerve. }\end{array}$ & 7 days & $\begin{array}{l}25 \% \text { demonstrated } \\
\text { by positive } \\
\text { immunofluoresce } \\
\text { nce for PMP- } 22 \text {. }\end{array}$ & $\begin{array}{l}\text { Glial morphology was } \\
\text { observed under a microscope. } \\
\text { Immunostaining for PMP-22 } \\
\text { and S-100. }\end{array}$ & No & [94] \\
\hline $\begin{array}{l}\text { Culture in } \\
\text { conditione } \\
\text { d medium } \\
\text { with } \\
\text { neurons of } \\
\text { mouse } \\
\text { cerebellar } \\
\text { granules. }\end{array}$ & $\begin{array}{l}\text { The bone } \\
\text { marrow } \\
\text { of adult } \\
\text { Wistar } \\
\text { rat. }\end{array}$ & $\begin{array}{l}\text { CMM was } \\
\text { cultured in a } \\
\text { conditioned } \\
\text { medium with } \\
\text { C57BL/6 mouse } \\
\text { cerebellar } \\
\text { granules } \\
\text { neurons. }\end{array}$ & 5 days & $\begin{array}{l}40 \% \text { and } 19 \% \\
\text { were } \\
\text { demonstrated by } \\
\text { positive } \\
\text { immunofluoresce } \\
\text { nce for GFAP and } \\
\text { NeuN, } \\
\text { respectively. }\end{array}$ & $\begin{array}{l}\text { Neuronal morphology was } \\
\text { observed under a microscope. } \\
\text { Immunostaining for Tuj1, } \\
\text { NeuN, and GFAP. }\end{array}$ & $\begin{array}{l}\text { Negative } \\
\text { resting } \\
\text { membrane } \\
\text { potential and } \\
\text { presence of } \\
\text { voltage-gated } \\
\mathrm{Na}^{+} \text {and } \mathrm{K}^{+} \\
\text {channels. } \\
\text { Ability to evoke } \\
\text { electric } \\
\text { currents in } \\
\text { response to } \\
\text { GABA, glycine, } \\
\text { and glutamate, } \\
\text { demonstrated } \\
\text { by } \\
\text { Patch-clamp. }\end{array}$ & [95] \\
\hline $\begin{array}{l}\text { Medium } \\
\text { conditionin } \\
\text { g of } \\
\text { olfactory } \\
\text { enveloping } \\
\text { cells of } \\
\text { Wistar rats. }\end{array}$ & $\begin{array}{l}\text { Adipose } \\
\text { tissue of } \\
\text { adult } \\
\text { humans }\end{array}$ & $\begin{array}{l}\text { The CMMs were } \\
\text { co-cultured with } \\
\text { olfactory } \\
\text { envelope cells } \\
\text { isolated from the } \\
\text { olfactory bulb of } \\
\text { a 2-day-old } \\
\text { Wistar rat. }\end{array}$ & 7 days & $\begin{array}{l}95 \%, 46 \%, 30 \% \\
\text { and } 72 \% \\
\text { demonstrated by } \\
\text { positive } \\
\text { immunofluoresce } \\
\text { nce for } \\
\text { PGP9.5, MAP2, } \\
\text { Synapsin I, and } \\
\text { GFAP, } \\
\text { respectively. }\end{array}$ & $\begin{array}{l}\text { Neuronal morphology was } \\
\text { observed under a microscope. } \\
\text { Immunostaining for Nestin, } \\
\text { PGP 9.5, MAP2, Synapsin I, } \\
\text { and GFAP. }\end{array}$ & No & [96] \\
\hline
\end{tabular}

Table S6. Breakdown of publications using gene transfection to induce neuronal differentiation of MSCs.

\begin{tabular}{|c|c|c|c|c|c|c|c|}
\hline Inductor & $\begin{array}{l}\text { Origin of } \\
\text { CMMs }\end{array}$ & Steps & Time & $\begin{array}{l}\text { Percentage of } \\
\text { differentiation } \\
\text { reported }\end{array}$ & $\begin{array}{l}\text { Technique used to } \\
\text { demonstrate differentiation }\end{array}$ & Functionality & Reference \\
\hline $\begin{array}{l}\text { Shh, FGF8, } \\
\text { and bFGF } \\
\text { in CMM } \\
\text { with REST } \\
\text { drop. }\end{array}$ & $\begin{array}{l}\text { The bone } \\
\text { marrow } \\
\text { of adult } \\
\text { humans. }\end{array}$ & $\begin{array}{l}\text { Ip RNA vectors } \\
\text { were transfected } \\
\text { against REST in } \\
\text { CMM before } \\
\text { induction with } \\
250 \mathrm{ng} / \mathrm{ml} \text { of } \\
\mathrm{SHH}, 100 \mathrm{ng} / \mathrm{ml} \\
\text { of FGF8, and } 50 \\
\mathrm{ng} / \mathrm{ml} \text { of bFGF. }\end{array}$ & 12 days & $\begin{array}{l}90 \% \text { and } 68.7 \% \\
\text { demonstrated by } \\
\text { Positive } \\
\text { Immunofluoresce } \\
\text { nce for NeuN } \\
\text { AND TH, } \\
\text { respectively. }\end{array}$ & $\begin{array}{l}\text { Neuronal morphology was } \\
\text { observed under a } \\
\text { microscope. } \\
\text { Increased TH, NaV11, NeuN, } \\
\text { Pitx3, and Nurr1 by WB. }\end{array}$ & $\begin{array}{l}\text { Presence of } \\
\text { spontaneous } \\
\text { discharges and } \\
\text { spontaneous } \\
\text { postsynaptic } \\
\text { currents } \\
\text { demonstrated } \\
\text { by Patch-clamp. }\end{array}$ & [99] \\
\hline
\end{tabular}




\section{Continued}

\begin{tabular}{|c|c|c|c|c|c|c|c|}
\hline $\begin{array}{l}\text { Transfectio } \\
\mathrm{n} \text { of RNAip } \\
\text { against } \\
\text { REST1. }\end{array}$ & $\begin{array}{l}\text { Adult } \\
\text { human } \\
\text { bone } \\
\text { marrow }\end{array}$ & $\begin{array}{l}\text { CMM was } \\
\text { transfected with } \\
\text { a lentiviral vector } \\
\text { containing an } \\
\text { IpRNA directed } \\
\text { against REST1. }\end{array}$ & & $\begin{array}{l}80 \% \text { demonstrated } \\
\text { by morphological } \\
\text { changes of } \\
\text { neuronal nature }\end{array}$ & $\begin{array}{l}\text { Neuronal morphology was } \\
\text { observed under a } \\
\text { microscope. } \\
\text { Expression of Novo NSE, } \\
\text { BDNF, NGN1, SYP, and } \\
\text { SCG10 by RT-PCR. } \\
\text { Immunostaining for } \\
\beta \text {-tubulin III, NF-200, } \\
\text { MAP-2, and NSE. Presence } \\
\text { of Nissl bodies by toluidine } \\
\text { blue staining. }\end{array}$ & $\begin{array}{l}\text { Presence of } \mathrm{Na}^{+} \\
\text {currents, which } \\
\text { can be blocked } \\
\text { with TTX, and } \\
\text { generation of } \\
\text { spontaneous } \\
\text { action potentials } \\
\text { demonstrated } \\
\text { by Patch clamp }\end{array}$ & [100] \\
\hline $\begin{array}{l}\text { Exogenous } \\
\text { expression } \\
\text { of the } \\
\text { LMX1b } \\
\text { factor in } \\
\text { the } \\
\text { presence of } \\
\text { FGF-2, } \\
\text { FGF-8, and } \\
\text { SHH }\end{array}$ & $\begin{array}{l}\text { Adult } \\
\text { human } \\
\text { bone } \\
\text { marrow }\end{array}$ & $\begin{array}{l}\text { CMM was } \\
\text { transfected with a } \\
\text { lentiviral vector } \\
\text { containing the } \\
\text { sequence of the } \\
\text { LMX1a gene } \\
\text { under the } \\
\text { cytomegalovirus } \\
\text { promoter before } \\
\text { induction with } 20 \\
\text { ng/ml of FGF-2, } \\
100 \mathrm{ng} / \mathrm{ml} \mathrm{FGF-8,} \\
\text { and } 1.7 \mathrm{nM} \mathrm{Shh} \text {. }\end{array}$ & 21 days & $\begin{array}{l}90 \% \text { demonstrated } \\
\text { by positive } \\
\text { immunofluoresce } \\
\text { nce for Tuj1. }\end{array}$ & $\begin{array}{l}\text { Neuronal morphology was } \\
\text { observed under a } \\
\text { microscope. } \\
\text { Increased expression of Sox2, } \\
\text { MSX1, NGN2, hASG1, En1, } \\
\text { and Pitx3 and VMAT2 by } \\
\text { RT-PCR. } \\
\text { Immunostaining for MSX1, } \\
\text { En1, Pitx3, Tuj1, } \\
\text { synaptotagmine1, MAP2, } \\
\text { synapsin, TH, and VMAT2. } \\
\text { Presence of TH by WB. }\end{array}$ & $\begin{array}{l}\text { Dopamine } \\
\text { secretion is } \\
\text { independent of } \\
\text { depolarization } \\
\text { and increased in } \\
\text { the presence of } \\
\mathrm{KCl} \\
\text { demonstrated } \\
\text { by HPLC. }\end{array}$ & [101] \\
\hline $\begin{array}{l}\text { Ectopic } \\
\text { expression } \\
\text { of LMX1a } \\
\text { and } \\
\text { neurturin } \\
\text { in the } \\
\text { presence of } \\
\beta \text {-Me, RA, } \\
\text { bFGF, } \\
\text { FGF-8, and } \\
\text { Shh }\end{array}$ & $\begin{array}{l}\text { Human } \\
\text { umbilical } \\
\text { cord } \\
\text { Fetal }\end{array}$ & $\begin{array}{l}\text { The CMMs were } \\
\text { transfected with } \\
\text { lentiviral vectors } \\
\text { containing the } \\
\text { sequences of the } \\
\text { Lmxl } \alpha \text { and NTN } \\
\text { genes, before } \\
\text { their } \\
\text { pre-induction } \\
\text { with } \beta \text {-Me and } \\
\text { bFGF for } 24 \text { h } \\
\text { with subsequent } \\
\text { exposure to Shh, } \\
\text { FGF8, and RA. }\end{array}$ & 21 days & $\begin{array}{l}70 \% \text { demonstrated } \\
\text { by morphological } \\
\text { changes of } \\
\text { neuronal nature. }\end{array}$ & $\begin{array}{l}\text { Neuronal morphology was } \\
\text { observed under a } \\
\text { microscope. } \\
\text { Increased expression of TH, } \\
\text { Msx-1, Nestin, MAP-2, } \\
\text { Lmx1 } \beta \text {, Fox } 22 \text {, Pitx } 3 \text {, DAT, } \\
\beta \text {-tubulin III, Nurr1, and } \\
\text { EN1 by RT-PCR. } \\
\text { Immunostaining for NSE, } \\
\text { MAP-2, } \beta \text {-tubulin III, and } \\
\text { TH. }\end{array}$ & No & [102] \\
\hline $\begin{array}{l}\text { Transfectio } \\
\mathrm{n} \text { with ip } \\
\text { RNA } \\
\text { against } \\
\text { Caveolin } 1 \\
\text { and } \\
\text { exposure to } \\
\beta \text {-Me }\end{array}$ & $\begin{array}{l}\text { Adult } \\
\text { Wistar rat } \\
\text { bone } \\
\text { marrow }\end{array}$ & $\begin{array}{l}\text { The CMM were } \\
\text { transfected with } \\
\text { ip RNA against } \\
\text { caveolin } 1 \text {, } \\
\text { before } \\
\text { pre-induction } \\
\text { with } \beta \text {-M } 1 \mathrm{mM} \\
24 \text { h by and } \\
\text { subsequent } \\
\text { induction with } \\
\beta \text {-Me } 10 \mathrm{mM} \text {. }\end{array}$ & 6 days & $\begin{array}{l}55 \% \text { demonstrated } \\
\text { by morphological } \\
\text { changes of } \\
\text { neuronal nature. }\end{array}$ & $\begin{array}{l}\text { Neuronal morphology was } \\
\text { observed under a } \\
\text { microscope. } \\
\text { Increased expression of } \\
\text { MAP2 and NSE by RT-PCR. } \\
\text { Immunostaining for MAP2 } \\
\text { and NSE. }\end{array}$ & No & [123] \\
\hline
\end{tabular}




\section{Continued}

\begin{tabular}{|c|c|c|c|c|c|c|}
\hline $\begin{array}{l}\text { Ectopic } \\
\text { expression } \\
\text { of Olig2 } \\
\text { and Hb9 in } \\
\text { the } \\
\text { presence of } \\
\beta \text {-Me, } \\
\text { forskolin, } \\
\text { RA, bFGF, } \\
\text { and Shh. }\end{array}$ & $\begin{array}{l}\text { Adult } \\
\text { human } \\
\text { bone } \\
\text { marrow }\end{array}$ & $\begin{array}{l}\text { The CMMs were } \\
\text { transfected with } \\
\text { viral vectors } \\
\text { containing the } \\
\text { Olig2 and Hb9 } \\
\text { gene sequences } \\
\text { under the CMV } \\
\text { promoter before } \\
\text { pre-induction } \\
\text { with } \beta \text {-Me } 1 \mathrm{mM} \\
\text { per } 24 \mathrm{~h} \text { and } \\
\text { subsequent } \\
\text { exposure to } 1 \mu \mathrm{M} \\
\text { RA, } 5 \mu \mathrm{M} \mathrm{FSK} \text {, } \\
10 \mathrm{ng} / \mathrm{ml} \mathrm{bFGF,} \\
\text { and } 200 \mathrm{ng} / \mathrm{ml} \\
\text { Shh. }\end{array}$ & 9 days & $\begin{array}{l}32 \% \text { demonstrated } \\
\text { by morphological } \\
\text { changes of } \\
\text { neuronal nature. }\end{array}$ & $\begin{array}{l}\text { Neuronal morphology was } \\
\text { observed under a } \\
\text { microscope. } \\
\text { Immunostaining for NeuN, } \\
\text { NF-M, islet-1, and ChAT. } \\
\text { Increased expression of } \\
\text { NF-M, Islet-1, and VAChT } \\
\text { by RT-PCR. }\end{array}$ & $\begin{array}{l}\text { Negative resting [104] } \\
\text { membrane } \\
\text { potential and } \\
\text { presence of } \\
\text { evoked action } \\
\text { potentials } \\
\text { demonstrated } \\
\text { by Patch-clamp. }\end{array}$ \\
\hline $\begin{array}{l}\text { Gene } \\
\text { transfectio } \\
n \text { of NICD } \\
\text { in the } \\
\text { presence of } \\
\text { forskolin, } \\
\text { bFGF, } \\
\text { CTNF, and } \\
\text { GDNF }\end{array}$ & $\begin{array}{l}\text { Human } \\
\text { bone } \\
\text { marrow } \\
\text { adult }\end{array}$ & $\begin{array}{l}\text { The CMMs were } \\
\text { transfected with } \\
\text { a viral vector } \\
\text { containing the } \\
\text { pre-induction } \\
\text { NICD sequence } \\
\text { with FSK } 5 \mu \mathrm{M} \text {, } \\
\text { bFGF } 10 \mathrm{ng} / \mathrm{ml} \text {, } \\
\text { CNTF } 10 \mathrm{ng} / \mathrm{ml} \text {, } \\
\text { and GDNF } 50 \\
\text { ng/ml. }\end{array}$ & 5 days & $\begin{array}{l}90 \% \text { and } 41 \% \text { were } \\
\text { demonstrated by } \\
\text { positive } \\
\text { immunofluoresce } \\
\text { nce for MAP } 2 \mathrm{ab} \\
\text { and } 41 \% \mathrm{TH} \text {, } \\
\text { respectively. }\end{array}$ & $\begin{array}{l}\text { Neuronal morphology was } \\
\text { observed under a } \\
\text { microscope. } \\
\text { Immunostaining for MAP2, } \\
\text { NF-M, and B-III, TH. } \\
\text { RT-PCR increased Nurr1, } \\
\text { Lmx1b, En1, and Ptx3. } \\
\text {. }\end{array}$ & $\begin{array}{l}\text { Negative resting [105] } \\
\text { membrane } \\
\text { potential and } \\
\text { presence of } \\
\text { delayed } \mathrm{K}^{+} \\
\text {rectifier current } \\
\text { demonstrated } \\
\text { by Patch-clamp. } \\
\text { Release of } \\
\text { dopamine to the } \\
\text { medium } \\
\text { demonstrated } \\
\text { by ELISA. }\end{array}$ \\
\hline $\begin{array}{l}\text { Transfectio } \\
\mathrm{n} \text { of } \\
\text { Mir-125-b } \\
\text { and in the } \\
\text { presence of } \\
\beta \text {-Me }\end{array}$ & $\begin{array}{l}\text { The bone } \\
\text { marrow } \\
\text { of adult } \\
\text { Sprague- } \\
\text { Dawley } \\
\text { rat. }\end{array}$ & $\begin{array}{l}\text { The CMMs were } \\
\text { transfected with } \\
\text { mimic RNA of } \\
\text { miR-125b and } \\
\text { pre-induced with } \\
\beta \text {-Me } 1 \mathrm{mM} \text { per } \\
24 \mathrm{~h} \text {, to later be } \\
\text { exposed to } \beta \text {-Me } \\
3 \mathrm{mM} \text { and } \\
\text { DMSO } 2 \%\end{array}$ & 6 days & $\begin{array}{l}55 \% \text { demonstrated } \\
\text { by morphological } \\
\text { changes of } \\
\text { neuronal nature. }\end{array}$ & $\begin{array}{l}\text { Neuronal morphology was } \\
\text { observed under a } \\
\text { microscope. } \\
\text { Increased expression of } \\
\beta \text {-tubulin III, MAP-2, NF, } \\
\text { NSE, GFAP, and Nestin by } \\
\text { RT-PCR and WB. }\end{array}$ & [108] \\
\hline
\end{tabular}


Table S7. Breakdown of publications in which small molecules are used to induce neuronal differentiation of MSCs.

\begin{tabular}{|c|c|c|c|c|c|c|c|}
\hline Inductor & $\begin{array}{l}\text { Origin o } \\
\text { MSCs }\end{array}$ & & Time & $\begin{array}{l}\text { Percentage of } \\
\text { differentiation } \\
\text { reported }\end{array}$ & $\begin{array}{l}\text { Technique used to } \\
\text { demonstrate differentiation }\end{array}$ & Functionality & Reference \\
\hline $\begin{array}{l}\text { SB431542, } \\
\text { dorsomorp } \\
\text { hine, TSA, } \\
\text { RG-108, } \\
\text { 8-BrcAMP, } \\
\text { Rolipram } \\
\text { and bFGF. }\end{array}$ & $\begin{array}{l}\text { Human } \\
\text { bone } \\
\text { marrow } \\
\text { adult }\end{array}$ & $\begin{array}{l}\text { Induction with } \\
\text { TSA } 200 \mathrm{nM} \text {, } \\
\text { RG-108 } 10 \mu \mathrm{M} \text {, } \\
8 \text { BrcAMP } 300 \\
\mu \mathrm{M} \text {, Rolipram } 1 \\
\mu \mathrm{M} \text { and } 20 \mathrm{ng} \\
\text { bFGF, together } \\
\text { with } \\
\text { dorsomorphin } 2 \\
\mu \mathrm{M} \text { and } \\
\text { SB431542 } 2 \mu \mathrm{M} \text {. }\end{array}$ & $\begin{array}{l}3 \\
\text { weeks }\end{array}$ & $\begin{array}{l}95 \% \text { demonstrated } \\
\text { by morphological } \\
\text { changes of } \\
\text { neuronal nature. } \\
68.05 \% \text { and } \\
89.12 \% \text { were } \\
\text { demonstrated by } \\
\text { positive } \\
\text { immunofluorescen } \\
\text { ce for HT and } \\
\text { Nurr1, } \\
\text { respectively. }\end{array}$ & $\begin{array}{l}\text { Neuronal morphology was } \\
\text { observed under a microscope. } \\
\text { Immunostaining for Sox2, } \\
\text { NCAM, A2B5, NeuN, Map2, } \\
\text { B-tubulin III, NSE, Nurr-1, } \\
\text { ChAT, TH, NF, VGLUT1, } \\
\text { SYP, SYN-1, GAB VGAT, } \\
\text { GAD67, PITX3, and } \\
\text { synaptophysin. } \\
\text { Increased expression of Sox2, } \\
\text { Map2, B3T, NSE, Nurr-1, } \\
\text { ChAT, TH, NF, VGLUT1, } \\
\text { SYP, SYN-1, VGAT, GAD67, } \\
\text { and PITX3 by RT-PCR and } \\
\text { by WB. }\end{array}$ & $\begin{array}{l}\text { Synaptophysin } \\
\text { immunostaining } \\
\text { reveals } \\
\text { synapse-like } \\
\text { structures that } \\
\text { form between } \\
\text { differentiated } \\
\text { cells. } \\
\text { Presence of } \mathrm{K}^{+} \\
\text {current rectifier } \\
\text { demonstrated by } \\
\text { Patch-clamp. }\end{array}$ & {$[112]$} \\
\hline $\begin{array}{l}\text { SB431542 } \\
\text { and } \\
\text { Dorsomorp } \\
\text { hine }\end{array}$ & $\begin{array}{l}\text { Adipose } \\
\text { tissue of } \\
\text { adult } \\
\text { humans }\end{array}$ & $\begin{array}{l}\text { Induction with } \\
\text { Dorsomorphin } \\
2 \mu \mathrm{M} \text { and } \\
\text { SB431542 } 20 \\
\mu \mathrm{M}\end{array}$ & $\begin{array}{l}14 \\
\text { days }\end{array}$ & $\begin{array}{l}85 \% \text { demonstrated } \\
\text { by positive } \\
\text { immunofluorescen } \\
\text { ce for NSE. }\end{array}$ & $\begin{array}{l}\text { Neuronal morphology was } \\
\text { observed under a microscope. } \\
\text { RT-PCR increased Pax6, } \\
\text { Sox1, NF-200, NES, and } \\
\beta \text {-tubulin III. } \\
\text { Immunostaining for Pax6, } \\
\text { Sox1, NF-200, NES, and } \\
\beta \text {-tubulin III. } \\
\text { Activation via Erk1/2, PI3K, } \\
\text { and Akt by phosphorylation } \\
\text { and inhibition } \\
\text { phosphorylation SMAD 1/5/8 } \\
\text { and } 2 \text { WB. }\end{array}$ & $\begin{array}{l}\text { Neuronal } \\
\text { differentiation in } \\
\text { vivo when } \\
\text { implanted } \\
\text { subcutaneously } \\
\text { in SCID CB-17 } \\
\text { mice after } \\
\text { treatment with } \\
\text { DM and SB was } \\
\text { demonstrated by } \\
\text { expressing the } \\
\text { specific GAP43 } \\
\text { protein of the } \\
\text { axon growth } \\
\text { cone. }\end{array}$ & [113] \\
\hline $\begin{array}{l}\text { bFGF, } \\
\text { SB431542, } \\
\text { noggin, } \\
\text { LDN19328 } \\
\text { 9, ac. } \\
\text { ascorbic, } \\
\text { dbcAMP } \\
\text { and BDNF. }\end{array}$ & $\begin{array}{l}\text { Adipose } \\
\text { tissue of } \\
\text { adult } \\
\text { humans }\end{array}$ & $\begin{array}{l}\text { Pre-induction } \\
\text { with } 4 \mathrm{ng} / \mathrm{ml} \\
\mathrm{bFGF}, \mathrm{SB} 431542 \\
10 \mu \mathrm{M}, \text { noggin } \\
100 \mathrm{ng} / \mathrm{ml} \text { and } \\
\mathrm{LDN} 1932890.5 \\
\mu \mathrm{M} \text {, for } 8 \text { days. } \\
\text { Subsequent } \\
\text { treatment with } \\
200 \mu \mathrm{M} \text { of } \\
\text { ascorbic acid for } \\
14 \text { days. Finally, } \\
\text { exposure to } 50 \\
\mu \mathrm{M} \text { dbcAMP } \\
\text { and } 20 \mathrm{ng} / \mathrm{ml} \\
\text { BDNF}\end{array}$ & $\begin{array}{l}12 \\
\text { days. }\end{array}$ & $\begin{array}{l}93 \%, 37 \% \text {, and } \\
47 \% \text { were } \\
\text { demonstrated by } \\
\text { positive } \\
\text { immunofluorescen } \\
\text { ce for Tuj } 1, \text { GAD, } \\
\text { and GABA, } \\
\text { respectively. }\end{array}$ & $\begin{array}{l}\text { Neuronal morphology was } \\
\text { observed under a microscope. } \\
\text { Increased expression TuJ1, } \\
\text { MAP2, Dlx5, Lhx6, GAD67, } \\
\text { SCN1A, SCN5A, Nkx2.1, } \\
\text { Dlx2, Dlx5y Lhx6, vGat1, } \\
\text { vGlut2, GAD65, GAD67, } \\
\text { CALB2, and GABRA1 by } \\
\text { RT-PCR. Immunostaining for } \\
\text { Tuj 1, Pax6, MAP2, NeuN, } \\
\text { GFAP, OLIG2, NKX2.1, } \\
\text { DLX2, LHX6, GAD, and } \\
\text { GABA. }\end{array}$ & $\begin{array}{l}\text { Ability to trigger } \\
\text { action potentials, } \\
\text { presence of } \\
\text { voltage-activated } \\
\text { ionic currents, } \\
\text { and presence of } \\
\text { an inhibitory } \\
\text { postsynaptic } \\
\text { current when } \\
\text { exposed to } \\
\text { NMDAR and } \\
\text { AMPA } \\
\text { antagonists. }\end{array}$ & [114] \\
\hline
\end{tabular}




\section{Continued}

\begin{tabular}{|c|c|c|c|c|c|c|c|}
\hline $\begin{array}{l}\text { Fasudil and } \\
\text { bFGF }\end{array}$ & $\begin{array}{l}\text { Adult } \\
\text { Sprague- } \\
\text { Dawley } \\
\text { rat bone } \\
\text { marrow }\end{array}$ & $\begin{array}{l}\text { Pre-induction } \\
\text { with } 10 \mathrm{ng} / \mathrm{ml} \\
\text { of bFGF per } 24 \\
\text { h. Subsequent } \\
\text { induction with } \\
200 \mu \mathrm{mol} / \mathrm{ml} \text { of } \\
\text { fasudil. }\end{array}$ & $48 \mathrm{~h}$. & $\begin{array}{l}69.35 \%, 76.52 \% \text {, } \\
\text { and } 78.95 \% \\
\text { demonstrated by } \\
\text { positive } \\
\text { immunofluorescenc } \\
\text { e for NF-M, NSE, } \\
\text { and nestin, } \\
\text { respectively. }\end{array}$ & $\begin{array}{l}\text { Neuronal morphology was } \\
\text { observed under a microscope. } \\
\text { Increased expression of NSE, } \\
\text { nestin, B-catenin, and NF-M } \\
\text { by RT-PCR and WB. } \\
\text { Immunostaining for NF-M, } \\
\text { NSE, and nestin. }\end{array}$ & No & [115] \\
\hline $\begin{array}{l}\text { EGF, bFGF, } \\
\text { NGF, and } \\
\text { RA }\end{array}$ & $\begin{array}{l}\text { Fetal } \\
\text { human } \\
\text { umbilical } \\
\text { cord }\end{array}$ & $\begin{array}{l}\text { Pre-induction } \\
\text { with EGF } 20 \\
\mathrm{ng} / \mathrm{ml} \text { and } \\
\mathrm{bFGF} 20 \mathrm{ng} / \mathrm{ml} \text {. } \\
\text { Subsequent } \\
\text { induction with } \\
\text { Retinoic acid } \\
0.5 \mathrm{mM} \text { and } 100 \\
\mathrm{ng} / \mathrm{ml} \text { of NGF. }\end{array}$ & 1 week & $\begin{array}{l}66.2 \% \\
\text { demonstrated by } \\
\text { positive } \\
\text { immunofluorescen } \\
\text { ce for GFAP. }\end{array}$ & $\begin{array}{l}\text { Neuronal morphology was } \\
\text { observed under a microscope. } \\
\text { Increased Nestin expression, } \\
\text { necdin, musashi1, } \\
\text { pleiotrophin, glipcano } 4 \text {, and } \\
\text { GFAP by RT-PCR and WB. } \\
\text { Immunostaining for Musashi, } \\
\text { Tuj1, and GFAP. }\end{array}$ & No & [116] \\
\hline $\begin{array}{l}\text { bFGF, EGF, } \\
\text { RA, and } \\
\text { Shh. }\end{array}$ & $\begin{array}{l}\text { Adult } \\
\text { mouse } \\
\text { bone } \\
\text { marrow } \\
\text { C57BL6 }\end{array}$ & $\begin{array}{l}\text { Pre-induction } \\
\text { with bFGF } 20 \\
\mathrm{ng} / \mathrm{ml} \text { and EGF } \\
20 \mathrm{ng} / \mathrm{ml} \text { for } 7 \\
\text { days. Subsequent } \\
\text { induction with } \\
\text { RA } 2 \mathrm{mM} \text { and } \\
\text { Shh } 300 \mathrm{nM} \text {. }\end{array}$ & 7 days & $\begin{array}{l}40 \% \text { demonstrated } \\
\text { by positive } \\
\text { immunofluorescen } \\
\text { ce for Tuj } 1 \text { and } \\
\text { NF. }\end{array}$ & $\begin{array}{l}\text { Neuronal morphology was } \\
\text { observed under a microscope. } \\
\text { Immunostaining for Tuj1 and } \\
\text { NF. } \\
\text { Increased expression of Tuj1, } \\
\text { NSE, and NF by RT-PCR. }\end{array}$ & No & [117] \\
\hline $\begin{array}{l}\text { FGF2, } \\
\text { Forskolin, } \\
\text { IBMX, } \\
\text { BDNF, Shh } \\
\text { and RA. }\end{array}$ & $\begin{array}{l}\text { Adult } \\
\text { mouse } \\
\text { bone } \\
\text { marrow } \\
\text { C57BL6 }\end{array}$ & $\begin{array}{l}\text { Induction with } \\
10 \mathrm{ng} / \mathrm{ml} \text { of } \\
\text { FGF2, forskolin } \\
5 \mu \mathrm{M}, \mathrm{IBMX} \\
125 \mu \mathrm{M}, 50 \\
\mathrm{ng} / \mathrm{ml} \mathrm{BDNF} \text {, } \\
400 \mathrm{ng} / \mathrm{ml} \mathrm{Shh} \\
\text { and } 0.5 \mu \mathrm{M} \text { RA. }\end{array}$ & 7 days & $\begin{array}{l}80 \% \text { demonstrated } \\
\text { by positive } \\
\text { immunofluorescen } \\
\text { ce for Islet } 1 \text { and } \\
\text { Tau. }\end{array}$ & $\begin{array}{l}\text { Neuronal morphology was } \\
\text { observed under a microscope. } \\
\text { Immunostaining for Islet1, } \\
\text { Tau, MAP2, NeuN, } \\
\text { calretinin, and NF. } \\
\text { RT-PCR increased NSE, Tau, } \\
\text { VGLUT1, VGLUT2, GluR3, } \\
\text { and GluR4. }\end{array}$ & $\mathrm{NO}$ & [118] \\
\hline RA & $\begin{array}{l}\text { Human } \\
\text { bone } \\
\text { marrow }\end{array}$ & $\begin{array}{l}\text { induction with } \\
\text { RA } 30 \mu \mathrm{M} \text {. }\end{array}$ & $\begin{array}{l}12 \\
\text { days }\end{array}$ & $\begin{array}{l}80 \% \text { demonstrated } \\
\text { by positive } \\
\text { immunofluorescen } \\
\text { ce for NF and } \\
\text { MAP2. }\end{array}$ & $\begin{array}{l}\text { Neuronal morphology was } \\
\text { observed under a microscope. } \\
\text { Immunostaining for MAP2 } \\
\text { and synaptophysin. }\end{array}$ & $\begin{array}{l}\text { Negative resting } \\
\text { membrane } \\
\text { potential and } \\
\text { ability to generate } \\
\text { spontaneous } \\
\text { action potentials } \\
\text { demonstrated by } \\
\text { Patch-clamp. }\end{array}$ & [119] \\
\hline $\begin{array}{l}\text { EGF, } \\
\text { FGF-2, RA, } \\
\text { and BDNF. }\end{array}$ & $\begin{array}{l}\text { Adult } \\
\text { human } \\
\text { bone } \\
\text { marrow }\end{array}$ & $\begin{array}{l}\text { Pre-induction } \\
\text { with } 20 \mathrm{ng} / \mathrm{ml} \\
\text { FGF2 and } 20 \\
\text { EGF for } 5 \text { weeks. } \\
\text { Subsequent } \\
\text { induction with } \\
\text { RA } 0.5 \mu \mathrm{mol} \text { and } \\
\text { BDNF } 10 \mathrm{ng} / \mathrm{ml} \text {. }\end{array}$ & $\begin{array}{l}14 \\
\text { days. }\end{array}$ & $\begin{array}{l}42 \% \text { demonstrated } \\
\text { by positive } \\
\text { immunofluorescen } \\
\text { ce for Tuj1. }\end{array}$ & $\begin{array}{l}\text { Neuronal morphology was } \\
\text { observed under a microscope. } \\
\text { Immunostaining for Tuj1, } \\
\text { MAP2, GFAP, and Gal-c. }\end{array}$ & No & [121] \\
\hline
\end{tabular}




\section{Continued}

\begin{tabular}{|c|c|c|c|c|c|c|c|}
\hline $\begin{array}{l}\text { RA, BHA, } \\
\text { Ac. } \\
\text { valproic } \\
\text { and } \\
\text { forskolin }\end{array}$ & $\begin{array}{l}\text { The bone } \\
\text { marrow } \\
\text { of adult } \\
\text { Sprague- } \\
\text { Dawley } \\
\text { rat. }\end{array}$ & $\begin{array}{l}\text { Pre-induction } \\
\text { with RA } 1 \mu \mathrm{M} \\
\text { per } 24 \mathrm{~h} \text {. } \\
\text { Subsequent } \\
\text { induction with } \\
\mathrm{BHA} 160 \mu \mathrm{M} \text {, } \\
\mathrm{KCl} 20 \mathrm{mM} \text {, ac. } \\
\text { valproic } 1.6 \\
\mathrm{mM} \text {, forskolin } 8 \\
\mu \mathrm{M} \text {, } \\
\text { hydrocortisone } \\
0.8 \mu \mathrm{M} \text { and } 4 \\
\mu \mathrm{g} / \mathrm{ml} \text { of } \\
\text { insulin. }\end{array}$ & $24 \mathrm{~h}$. & $\begin{array}{l}83.17 \% \\
\text { demonstrated by } \\
\text { morphological } \\
\text { changes of } \\
\text { neuronal nature. }\end{array}$ & $\begin{array}{l}\text { Neuronal morphology was } \\
\text { observed under a microscope. } \\
\text { RT-PCR increased nestin, } \\
\text { NSE, MAP-2, Tau, and Tuj1. } \\
\text { Immunostaining for nestin, } \\
\text { NSE, Tuj1, and Tau and by } \\
\text { WB. }\end{array}$ & $\begin{array}{l}\text { Negative resting } \\
\text { membrane } \\
\text { potential, } \\
\text { demonstrated by } \\
\text { Patch-clamp. } \\
\text { Increased } \\
\text { intracellular } \mathrm{Ca}^{+} \\
\text {concentration } \\
\text { after } \mathrm{K}^{+} \\
\text {stimulation. }\end{array}$ & [122] \\
\hline RA & $\begin{array}{l}\text { The bone } \\
\text { marrow } \\
\text { of adult } \\
\text { Sprague- } \\
\text { Dawley } \\
\text { rat. }\end{array}$ & $\begin{array}{l}\text { Induction with } \\
\text { RA } 20 \mu \mathrm{M} \text {. }\end{array}$ & $48 \mathrm{~h}$. & $\begin{array}{l}80 \% \text { and } 70 \% \text { were } \\
\text { demonstrated by } \\
\text { positive } \\
\text { immunofluorescen } \\
\text { ce for NSE and } \\
\text { NF-H, } \\
\text { respectively. }\end{array}$ & $\begin{array}{l}\text { Neuronal morphology was } \\
\text { observed under a microscope. } \\
\text { RT-PCR increased NSE, } \\
\text { NF-H, } \beta \text {-tubulin III, and } \\
\text { MAP-2. } \\
\text { Immunostaining for NSE and } \\
\text { NF-H WB. }\end{array}$ & $\begin{array}{l}\text { Negative resting } \\
\text { membrane } \\
\text { potential, } \\
\text { demonstrated by } \\
\text { Patch-clamp. }\end{array}$ & [123] \\
\hline
\end{tabular}

